\section{International Scientific Journal} Theoretical \& Applied Science

p-ISSN: $2308-4944$ (print)

e-ISSN: 2409-0085 (online)

Year: 2017

Issue: 06

Volume: 50

Published: $16.06 .2017 \quad$ http://T-Science.org

SECTION 6. Metallurgy and energy.
Denis Chemezov

Master of Engineering and Technology, Corresponding Member of International Academy of Theoretical and Applied Sciences, Lecturer of Vladimir Industrial College, Russian Federation chemezov-da@yandex.ru

Margarita Bakhmeteva Master of Industrial Training, Vladimir Industrial College, Russian Federation margo.1958@list.ru

Anzhelika Bayakina Lecturer of Vladimir Industrial College,

Russian Federation bajakina.anzhelika@yandex.ru

Vladislav Polushin Student of Vladimir Industrial College, Russian Federation

Tatyana Lukyanova Lecturer of Vladimir Industrial College, Russian Federation

Alyona Igumentseva Lecturer of Vladimir Industrial College,

Russian Federation earthplanetally@yandex.ru

\title{
ANALYSIS OF THE MANUFACTURING PROCESS OF THE CASE- SHAPED CASTING IN THE SAND MOULD
}

Abstract: In the article there are considered the manufacturing stages of the casting of frame of the terminal box in the conditions of JSC "Vladimir electromotive plant». On the basis of the performed computer simulation of the casting process of the casting in the sand mould there were obtained the three-dimensional fields of cooling, the flow velocities and the Niyama criterion for gray cast iron. The time of cooling (solidification) of the alloy in the sand mould was determined. In accordance with the basic technological process of casting in the sand mould, the comparison of the admissible value of volumetric shrinkage of the casting material with the calculated value was performed.

Key words: a casting, melt, a model, time, temperature, filling, solidification, shrinkage, a sand mould.

Language: English

Citation: Chemezov D, Bakhmeteva M, Bayakina A, Polushin V, Lukyanova T, Igumentseva A (2017) ANALYSIS OF THE MANUFACTURING PROCESS OF THE CASE-SHAPED CASTING IN THE SAND MOULD. ISJ Theoretical \& Applied Science, 06 (50): 14-52.

Soi: http://s-o-i.org/1.1/TAS-06-50-2 Doi: crossef https://dx.doi.org/10.15863/TAS.2017.06.50.2

\section{Introduction}

Today JSC «Vladimir electromotive plant» (Russia) carries out the manufacturing of accessories and the assembly of the low voltage electric motors by power from 0.75 to $315 \mathrm{~kW}$ [1]. The main products of the enterprise are the three-phase asynchronous motors for the general industrial use. The motors of the special modification (explosionproof, single-phase, for the drive elevators, for the electric hoists and etc.) are produced also.
In addition to mechanical and assembly shops in the structure of JSC «Vladimir electromotive plant» includes the foundry shop and a number of the auxiliary productions which constitute LLS «LitVEMP». The nomenclature of LLC «Lit-VEMP» is 400 castings of gray cast iron GG10 (DIN), EN-GJL150 (EN), EN-GJL-200 (EN), CGI35 (ISO), CIB2 and aluminium ENAC-44200 (EN), G-AlSi10Mg (DIN) for the different modification of the electric motors. The dimensions accuracy and the geometry correctness of the castings are ensured by means of 


\begin{tabular}{|c|c|c|c|c|c|c|}
\hline Impact Factor: & $\begin{array}{l}\text { ISRA (India) } \\
\text { ISI (Dubai, UAB } \\
\text { GIF (Australia) } \\
\text { JIF }\end{array}$ & $\begin{array}{r}=1.344 \\
=0.829 \\
=0.564 \\
=1.500\end{array}$ & $\begin{array}{l}\text { SIS (USA) } \\
\text { PИHЦ (Russia) } \\
\text { ESJI (KZ) } \\
\text { SJIF (Morocco) }\end{array}$ & $\begin{array}{l}=0.912 \\
=0.234 \\
=3.860 \\
=\mathbf{2 . 0 3 1}\end{array}$ & $\begin{array}{l}\text { ICV (Poland) } \\
\text { PIF (India) } \\
\text { IBI (India) }\end{array}$ & $\begin{array}{l}=6.630 \\
=1.940 \\
=4.260\end{array}$ \\
\hline
\end{tabular}

the designing of the gated pattern in the computer program Pro/Engineer.

Grey iron has good casting properties. At high castability and low shrinkage of the material, it is possible to perform precision casting of the thinwalled castings. However, casting in the production conditions maybe accompanied by the dimensions change and (hidden) defects in the casting structure. This occurs during the deviation from the technological process of casting (particularly the massive iron casting). The poor quality casting will have mechanical, operational and other properties which don't correspond by the technical requirements. The risk of the partial fracture of the part/casting material (in depending purpose and operation mode of the assembly unit) is increased.

The computer simulation, which is as close as possible to the real technological process of casting, will allow to determine the possible defects in the casting structure and to perform corrective actions for their elimination.

\section{Materials and methods}

The technological process of casting of frame of the terminal box of the electric motor in the sand mould [2] is simulated.

The case-shaped part is intended for protection of the terminal box of the electric motor from ingress of dust and chip during the operation. The part «Frame of the terminal box» is the part of the threephase asynchronous motor with the squirrel-cage rotor (series $5 \mathrm{AMN}$ ). The electric motor of this series is modernized and protected with the height of the rotation axis of $315 \mathrm{~mm}$. The configuration and the dimensions of the part «Frame of the terminal box 5 AMN 315» are presented in Fig. $1-6$.

The technical requirements for the manufacturing of the part «Frame of the terminal box 5AMN $315 »$ :

1. Accuracy of the casting 9-0-9-6 GOST 26645-85 [3].

2. Limit deviations $3.210 \mathrm{cl}$. GOST 26645-85.

3 . The casting must comply by the factory standard 520011.014-99.

4. The pattern tapers by GOST 3212-92 [4] in the direction of increasing of the body casting.

5. Not specified foundry radii up to $3 \mathrm{~mm}$.

6. Coating of the casting in accordance with a climatic design.

7. * The dimensions for reference.

The main technological data for the implementation of the casting process are presented in the map of the technological information [5] (table 1). The basic technological process of the manufacturing casting with indication of the special equipment and the piece time on the performing of the each operation is presented in table 2.

On the drilling machine the processing of ten through-holes by a diameter of $8 \mathrm{~mm}$ and four through-holes by a diameter of $12 \mathrm{~mm}$ is done.

The operation of chipping and finishing consists of six technological steps.

Chipping of the (gates) feeders is occurred on the first step. The cross sectional area of the (gates) feeders is $5.6 \mathrm{~cm}^{2}$.

On the second step, chipping of the flashes at the parting line of the sand mould is exercised. A length of the flash up to $1500 \mathrm{~mm}$ at a thickness of 2 $\mathrm{mm}$.

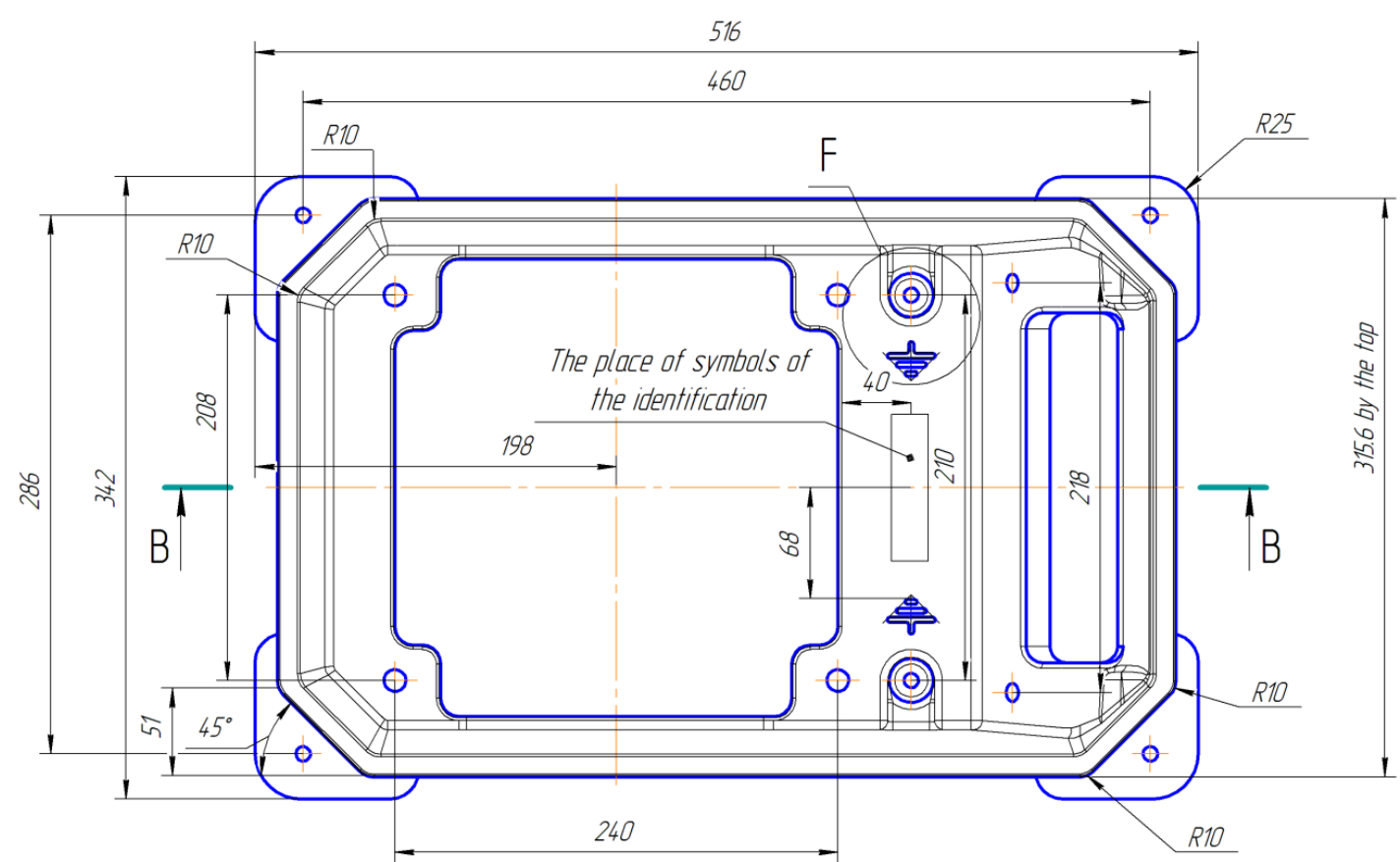

Figure 1 - The drawing of the part «Frame of the terminal box 5AMN 315». Top view. 


\begin{tabular}{l|lrl|l|ll} 
& ISRA (India) & $=\mathbf{1 . 3 4 4}$ & SIS (USA) & $=\mathbf{0 . 9 1 2}$ & ICV (Poland) & $=\mathbf{6 . 6 3 0}$ \\
Impact Factor: & ISI (Dubai, UAE) $=\mathbf{0 . 8 2 9}$ & PUHU (Russia) $=\mathbf{0 . 2 3 4}$ & PIF (India) & $=\mathbf{1 . 9 4 0}$ \\
& GIF (Australia) & $\mathbf{0 . 5 6 4}$ & ESJI (KZ) & $=\mathbf{3 . 8 6 0}$ & IBI (India) & $=\mathbf{4 . 2 6 0}$
\end{tabular}

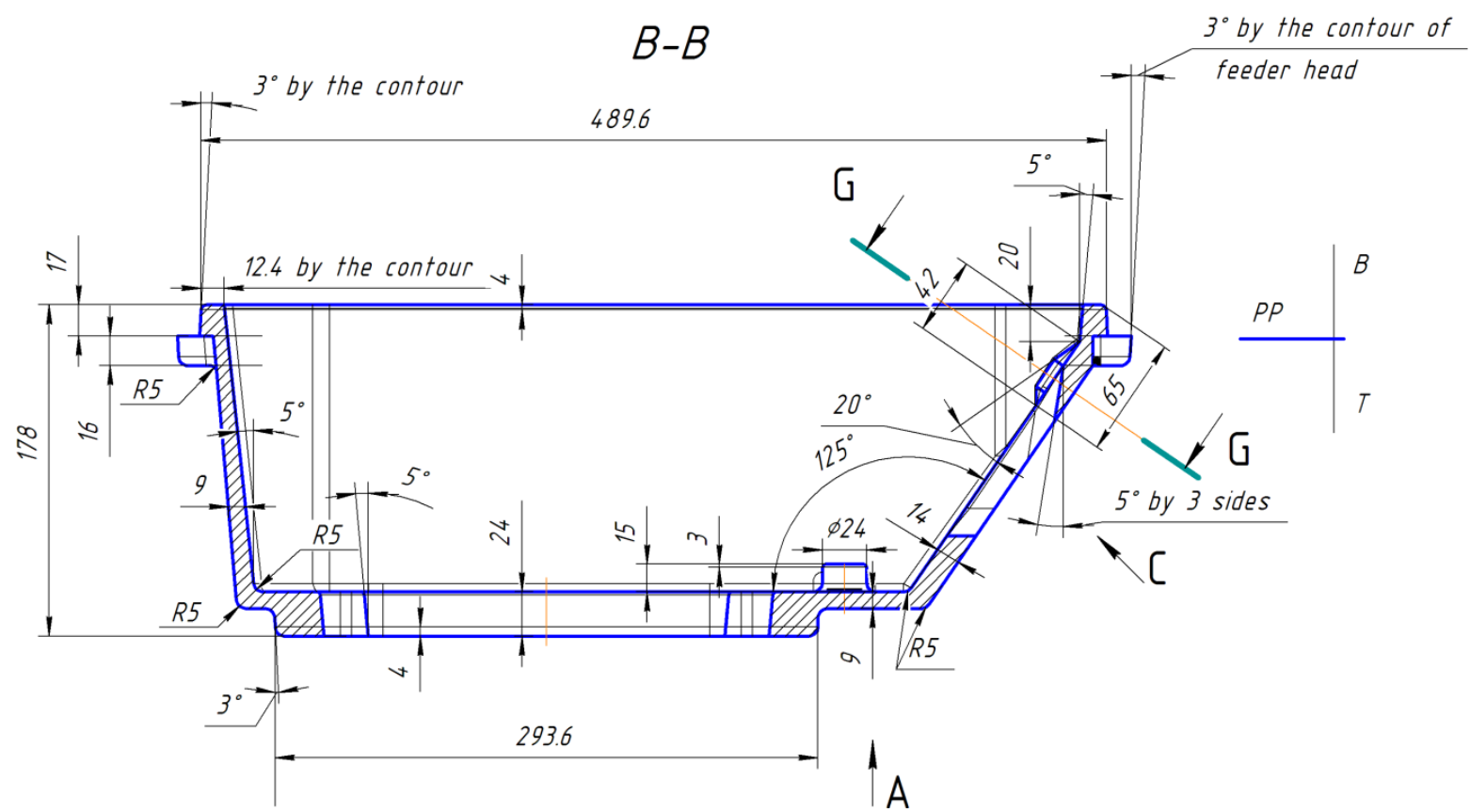

Figure 2 - The drawing of the part «Frame of the terminal box 5AMN 315». Longitudinal section B-B.

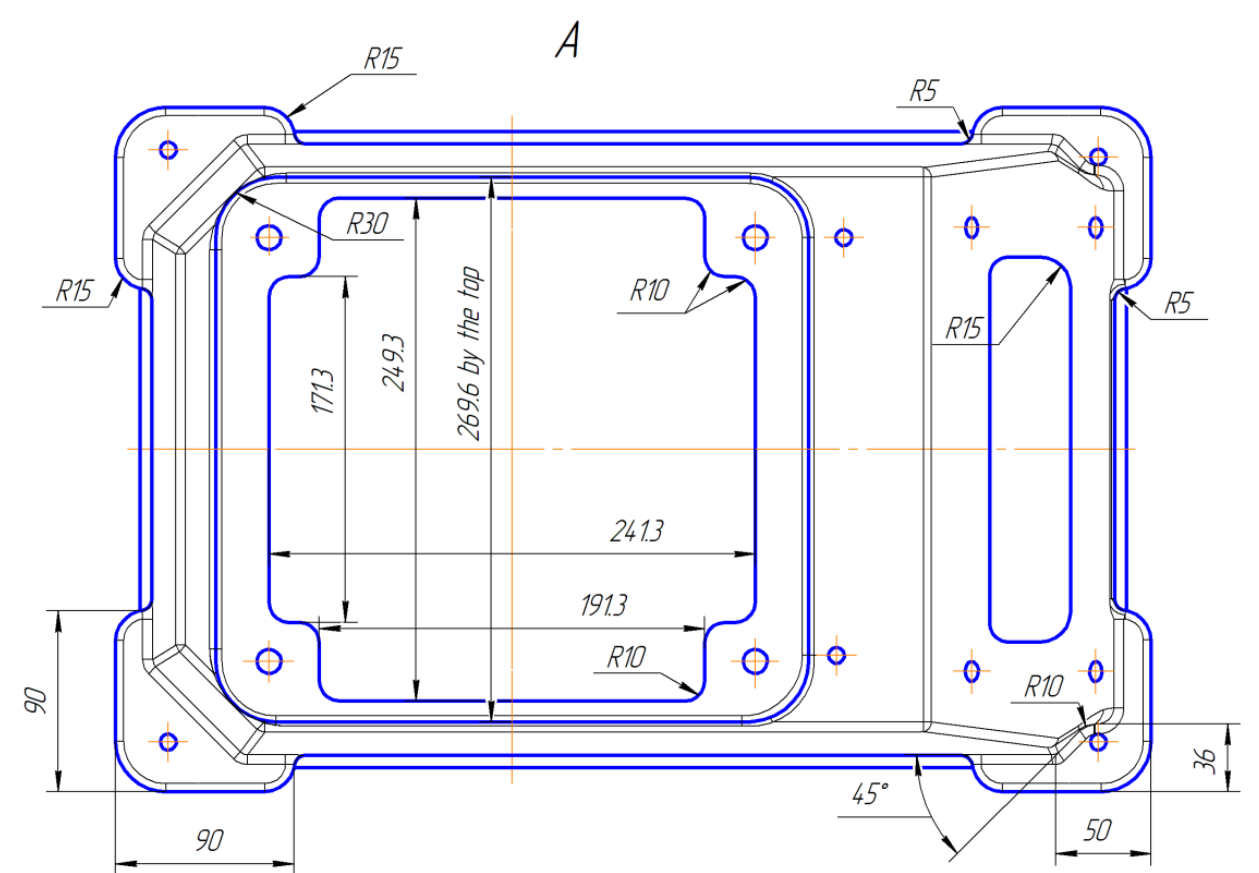

Figure 3 - The drawing of the part «Frame of the terminal box 5AMN 315». View A. 


\begin{tabular}{l|lrl|l|ll} 
& ISRA (India) & $=\mathbf{1 . 3 4 4}$ & SIS (USA) & $=\mathbf{0 . 9 1 2}$ & ICV (Poland) & $=\mathbf{6 . 6 3 0}$ \\
Impact Factor: & ISI (Dubai, UAE) $=\mathbf{0 . 8 2 9}$ & PUHU (Russia) $=\mathbf{0 . 2 3 4}$ & PIF (India) & $=\mathbf{1 . 9 4 0}$ \\
& GIF (Australia) & $\mathbf{0 . 5 6 4}$ & ESJI (KZ) & $=\mathbf{3 . 8 6 0}$ & IBI (India) & $=\mathbf{4 . 2 6 0}$
\end{tabular}

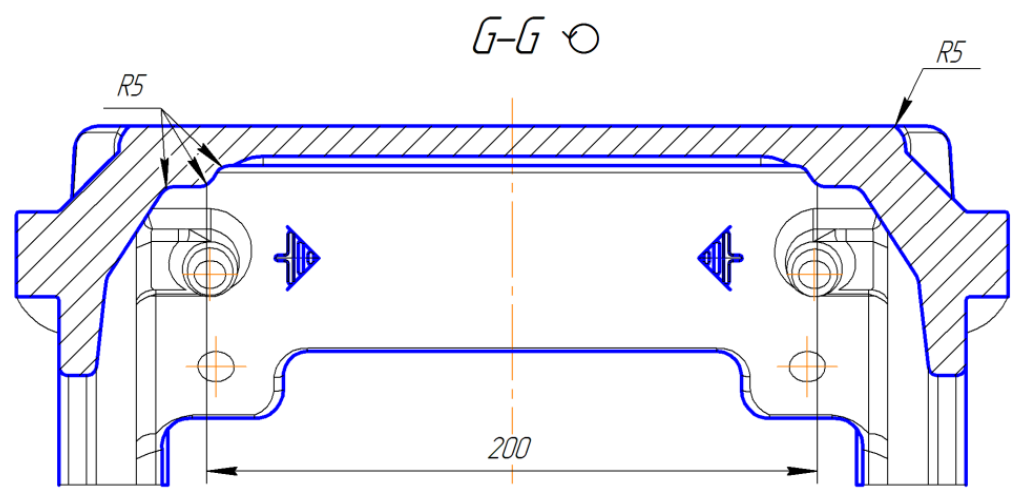

Figure 4 - The drawing of the part «Frame of the terminal box 5AMN 315». Cross section G-G (rotated).
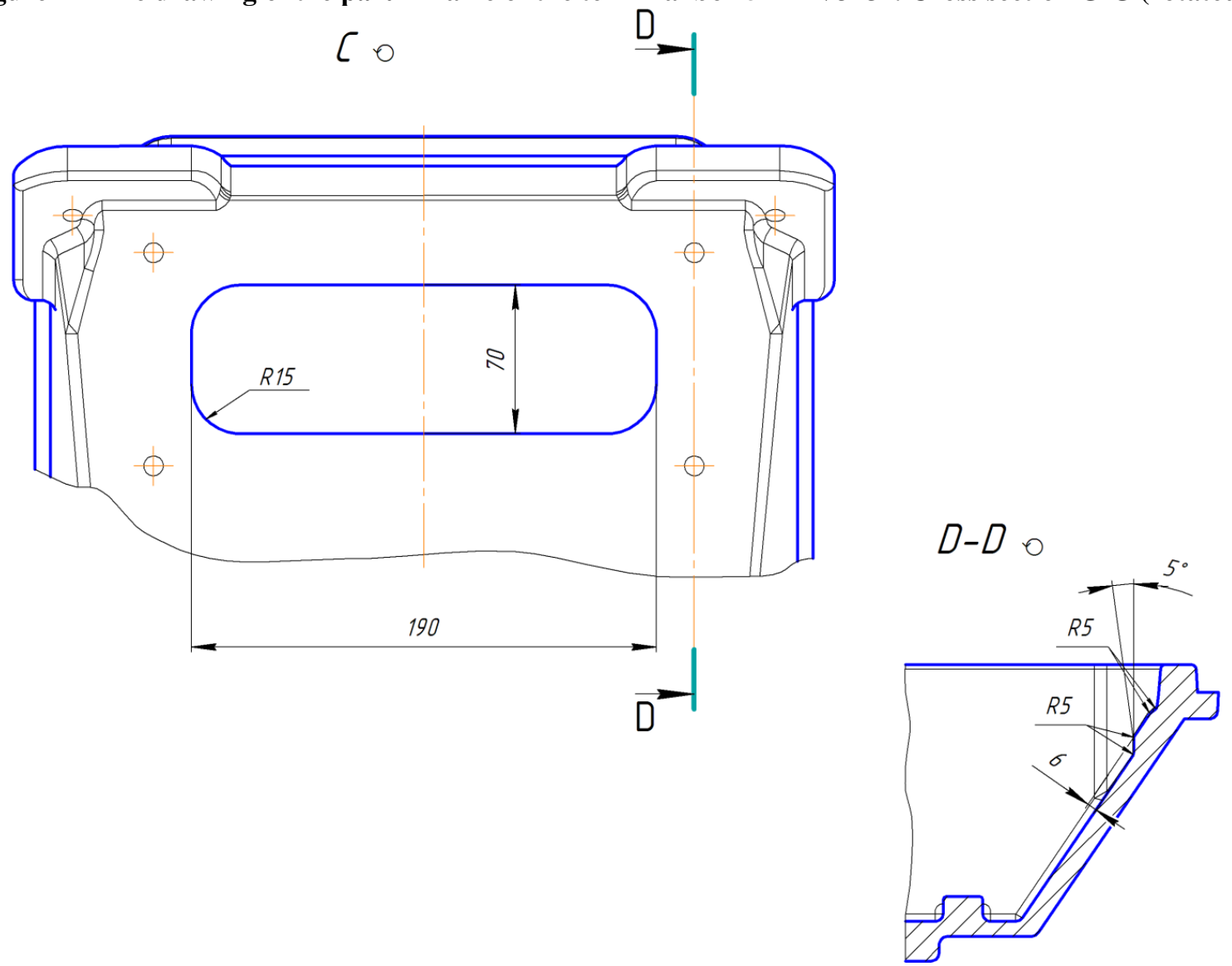

Figure 5 - The drawing of the part «Frame of the terminal box 5AMN 315». View C (rotated), longitudinal section D-D (rotated). 


\begin{tabular}{l|lrl|l|ll} 
& ISRA (India) & $=\mathbf{1 . 3 4 4}$ & SIS (USA) & $=\mathbf{0 . 9 1 2}$ & ICV (Poland) & $=\mathbf{6 . 6 3 0}$ \\
Impact Factor: & ISI (Dubai, UAE) $=\mathbf{0 . 8 2 9}$ & PVHU (Russia) $=\mathbf{0 . 2 3 4}$ & PIF (India) & $=\mathbf{1 . 9 4 0}$ \\
& GIF (Australia) & $\mathbf{0 . 5 6 4}$ & ESJI (KZ) & $=\mathbf{3 . 8 6 0}$ & IBI (India) & $\mathbf{4 . 2 6 0}$
\end{tabular}
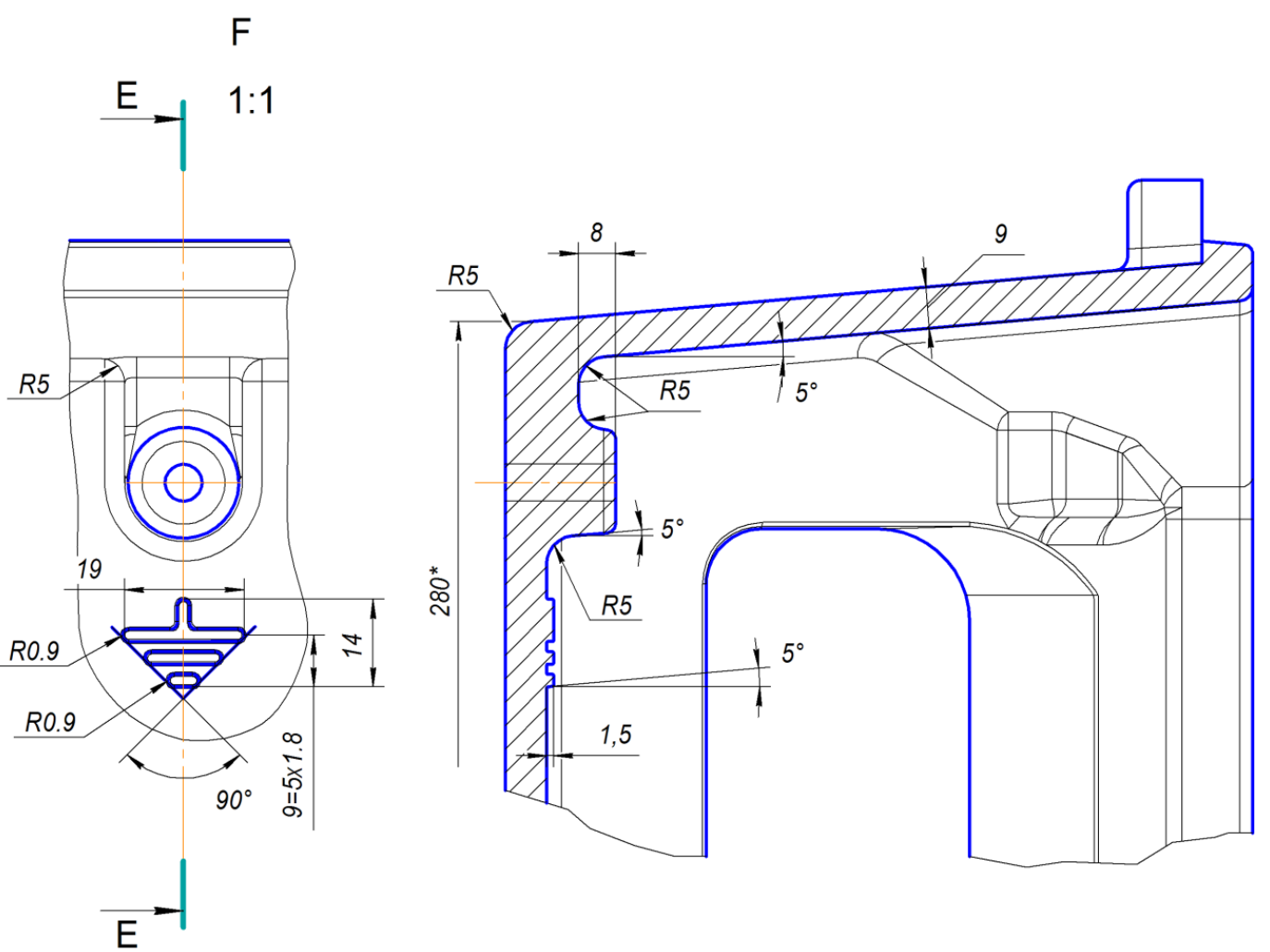

Figure 6 - The drawing of the part «Frame of the terminal box 5AMN 315». Removal element F, cross section E-E.

Table 1

The technological information of the casting process.

\begin{tabular}{|c|c|}
\hline $\begin{array}{l}\text { Number of the complexity criterion according to the } \\
\text { price list №25-01 }\end{array}$ & $1 \ldots 10$ \\
\hline $\begin{array}{l}\text { The complexity group of the casting on the basis } \\
\text { of the complexity criterion }\end{array}$ & $1-3,2-1,3-1,4-5,5-2,6-1,7-1,8-3,9-3,10-4$ \\
\hline Adopted by the complexity group of the casting & 2 \\
\hline $\begin{array}{c}\text { The complexity group by assignment, responsibility } \\
\text { and requirements }\end{array}$ & 3 \\
\hline $\begin{array}{l}\text { The accuracy class of cast iron and steel } \\
\text { castings according to GOST 26645, } \\
\text { or other classifiers for non-ferrous casting }\end{array}$ & 9 \\
\hline $\begin{array}{l}\text { The unit of rationing, which is set } \\
\text { the consumption rate of the material }\end{array}$ & 1 \\
\hline Shrinkage & $1 \%$ \\
\hline The quantity of castings in the mould & 1 \\
\hline A length of the flask in the light & $650 \mathrm{~mm}$ \\
\hline A width of the flask in the light & $540 \mathrm{~mm}$ \\
\hline A height of the flask in the light & $350 \mathrm{~mm}$ \\
\hline Mass & $110 \mathrm{~kg}$ \\
\hline Mass of moulding sand & $370 \mathrm{~kg}$ \\
\hline The type of the sand mould & Sand-and-clay \\
\hline The melting unit & Cupola, $\mathrm{Q}=5 \mathrm{t} / \mathrm{hr}$ \\
\hline The temperature of metal during filling of the mould & $1320-1330^{\circ} \mathrm{C}$ \\
\hline The bucket capacity & $500 \mathrm{~kg}$ \\
\hline The exposure time of the casting in the mould & $24 \min$ \\
\hline
\end{tabular}




\begin{tabular}{|c|c|c|c|c|c|c|}
\hline Impact Factor: & $\begin{array}{l}\text { ISRA (India) } \\
\text { ISI (Dubai, UAE } \\
\text { GIF (Australia) } \\
\text { JIF }\end{array}$ & $\begin{array}{l}=1.344 \\
=0.829 \\
=0.564 \\
=1.500\end{array}$ & $\begin{array}{l}\text { SIS (USA) } \\
\text { PИНЦ (Russia) } \\
\text { ESJI (KZ) } \\
\text { SJIF (Morocco) }\end{array}$ & $\begin{array}{l}=0.912 \\
=0.234 \\
=3.860 \\
=\mathbf{2 . 0 3 1}\end{array}$ & $\begin{array}{l}\text { ICV (Poland) } \\
\text { PIF (India) } \\
\text { IBI (India) }\end{array}$ & $\begin{array}{l}=6.630 \\
=1.940 \\
=4.260\end{array}$ \\
\hline
\end{tabular}

The technological process of the manufacturing casting by casting in the sand mould.

Table 2

\begin{tabular}{|c|c|c|c|}
\hline Operation & Operation name & Equipment & Piece time, min \\
\hline 010 & Preparation of charge material & Gantry crane (2 pieces) & 0.4 \\
\hline 020 & Charge drawing and bulk charging & $\begin{array}{l}\text { Beam crane (1 piece); } \\
\text { Weighing cart; } \\
\text { Tipping bucket }\end{array}$ & 1.447 \\
\hline 030 & Melting of metal & Cupola, $\mathrm{Q}=5 \mathrm{t} / \mathrm{hr}(1$ piece $)$ & 0.483 \\
\hline 040 & Preparation of moulding materials & $\begin{array}{l}\text { Rotary drier (1 piece); } \\
\text { Clay mixer (1 piece) }\end{array}$ & 0.4122 \\
\hline 050 & Preparation of moulding sand & Mixers (2 pieces) & 2.8855 \\
\hline 060 & Moulding & Moulding machine (2 pieces) & 2.69 \\
\hline 070 & $\begin{array}{l}\text { Material handling on pouring and knock- } \\
\text { out of the moulds }\end{array}$ & Floor conveyor (1 piece) & \\
\hline 080 & Pouring & $\begin{array}{l}\text { Mechanical hanger (1 piece); } \\
\text { Ladle }\end{array}$ & 0.957 \\
\hline 090 & Release of the flasks & & 0.2061 \\
\hline 100 & Knock-out of the castings & $\begin{array}{c}\text { Mechanical eccentric vibrating } \\
\text { grid (1 piece); } \\
\text { Jib crane; } \\
\text { Sledgehammer; } \\
\text { Hook } \\
\end{array}$ & 1.253 \\
\hline 110 & $\begin{array}{l}\text { Reweighting of the castings from the } \\
\text { overhead conveyor-3 to the overhead } \\
\text { conveyor shot-blasting chamber }\end{array}$ & $\begin{array}{c}\text { Overhead electric hoist, } \\
\text { capacity - } 250 \mathrm{~kg} \text { (1 piece); } \\
\text { Hook; } \\
\text { Hook for shot-blasting chamber }\end{array}$ & 0.244 \\
\hline 120 & $\begin{array}{l}\text { Finishing of the castings from the ground } \\
\text { and burn on, reweighting them on the } \\
\text { overhead conveyor-5 }\end{array}$ & $\begin{array}{c}\text { Shot-blasting chamber }(1 \\
\text { piece); } \\
\text { Overhead electric hoist, } \\
\text { capacity - } 250 \mathrm{~kg}(1 \text { piece); } \\
\text { Hook }\end{array}$ & 0.58 \\
\hline 130 & $\begin{array}{l}\text { Removal of the castings from the } \\
\text { overhead conveyor- } 5\end{array}$ & $\begin{array}{c}\text { Overhead electric hoist, } \\
\text { capacity }-250 \mathrm{~kg}(1 \text { piece }) \\
\text { Hook }\end{array}$ & 0.244 \\
\hline 140 & Chipping and finishing & $\begin{array}{l}\text { Tool-and-cutter grinding } \\
\text { machine (1 piece); } \\
\text { Pneumatic grinder; } \\
\text { Forging chipper; } \\
\text { Sledgehammer }\end{array}$ & \\
\hline 150 & The inspection of the castings & & \\
\hline 160 & $\begin{array}{c}\text { Hanging of casting on the conveyor of } \\
\text { priming chamber }\end{array}$ & $\begin{array}{c}\text { Overhead electric hoist, } \\
\text { capacity - } 250 \mathrm{~kg}(1 \text { piece); } \\
\text { Hook; } \\
\text { Hanger } \\
\end{array}$ & 0.206 \\
\hline 170 & Priming of casting & $\begin{array}{c}\text { Priming chamber (1 piece); } \\
\text { Hanger }\end{array}$ & 0.206 \\
\hline 180 & $\begin{array}{l}\text { Removal of casting from the priming } \\
\text { conveyor }\end{array}$ & $\begin{array}{c}\text { Overhead electric hoist, } \\
\text { capacity }-250 \mathrm{~kg}(1 \text { piece }) \\
\text { Hook }\end{array}$ & 0.206 \\
\hline 190 & The inspection of casting after priming & & \\
\hline 200 & $\begin{array}{c}\text { Transporting of casting in the machine } \\
\text { shop }\end{array}$ & $\begin{array}{c}\text { Beam crane, capacity - } 2.0 \text { t (1 } \\
\text { piece); } \\
\text { Battery-driven truck; } \\
\text { Bank }\end{array}$ & 0.489 \\
\hline \multicolumn{3}{|c|}{ Total time: } & 12.9088 \\
\hline
\end{tabular}

ISPC Technology and Education, 


\begin{tabular}{|c|c|c|c|c|c|c|}
\hline Impact Factor: & $\begin{array}{l}\text { ISRA (India) } \\
\text { ISI (Dubai, UAF } \\
\text { GIF (Australia) } \\
\text { JIF }\end{array}$ & $\begin{array}{l}=1.344 \\
=0.829 \\
=0.564 \\
=1.500\end{array}$ & $\begin{array}{l}\text { SIS (USA) } \\
\text { PИНЦ (Russia) } \\
\text { ESJI (KZ) } \\
\text { SJIF (Morocco) }\end{array}$ & $\begin{array}{l}=0.912 \\
=0.234 \\
=3.860 \\
=\mathbf{2 . 0 3 1}\end{array}$ & $\begin{array}{l}\text { ICV (Poland) } \\
\text { PIF (India) } \\
\text { IBI (India) }\end{array}$ & $\begin{array}{l}=6.630 \\
=1.940 \\
=4.260\end{array}$ \\
\hline
\end{tabular}

On the third step, chipping of metal penetration and sand fusion, scabs, surface contaminations, knobs as needed on internal and external surfaces of the casting is performed. The chipping area up to 600 $\mathrm{cm}^{2}$.

On the fourth step, finishing of the traces of the feeders is produced. The cross sectional area of the (gates) feeders is $5.6 \mathrm{~cm}^{2}$. As a cutting tool the grinding wheel $1.600 \times 80 \times 30614 \mathrm{~A} \mathrm{~F} 22 \mathrm{~N} 7$ V 35 $\mathrm{m} / \mathrm{s} 1 \mathrm{cl}$. A GOST 2424-83 [6] is used.

On the fifth step, chipping of the flash at the parting line of the sand mould is performed. A length of the flash up to $1500 \mathrm{~mm}$ at a thickness of $0.5-2$ $\mathrm{mm}$.

On the sixth step, finishing of metal penetration and sand fusion, scabs and knobs in places where available by sharpening of the grinder is performed. The finishing area up to $600 \mathrm{~cm}^{2}$. As a cutting tool the grinding wheel $1.150 \times 10 \times 3214$ A F40 N 7 B 40 $\mathrm{m} / \mathrm{s} 1 \mathrm{cl}$. A GOST $2424-83$ is used.

The inspection operation is performed after casting and priming of the casting. The inspection is subjected the appearance of the casting for the detection of blowholes, cracks and other defects. The inspection is subjected the dimensions of the casting according to the drawing and the sketch of the casting. The inspection is $2 \%$. The inspection is subjected the mechanical properties, chemical composition and the structure of an alloy. The appearance of the casting (the inspection is $100 \%$ ) is inspected after priming visually.

The gated pattern consists of the model plates top and bottom. The elements of the gating system are:

- the pouring basin and the sprue, which are used for reception of the stream and supply of melt at the height of the sand mould respectively;

- the dirt trap, located in the cope and used for capture of the various inclusions in melt;

- four (gates) feeders, used for supply melt directly in the mould cavity.

The configuration of the sand mould and dimensions of the elements of the gating system are presented in Fig. 7.

The three-dimensional solid model of the casting (without elements of the gating system) was created through the tools of the computer program KOMPAS-3D (Fig. 8 -9).

The percentage of the chemical elements in the alloy EN-GJL-150 is presented in table 3. The percentage of the chemical elements in the table was determined for the alloy in the liquid state.

Thermophysical conditions of the casting process of grey cast iron in the sand mould are presented in table 4 .
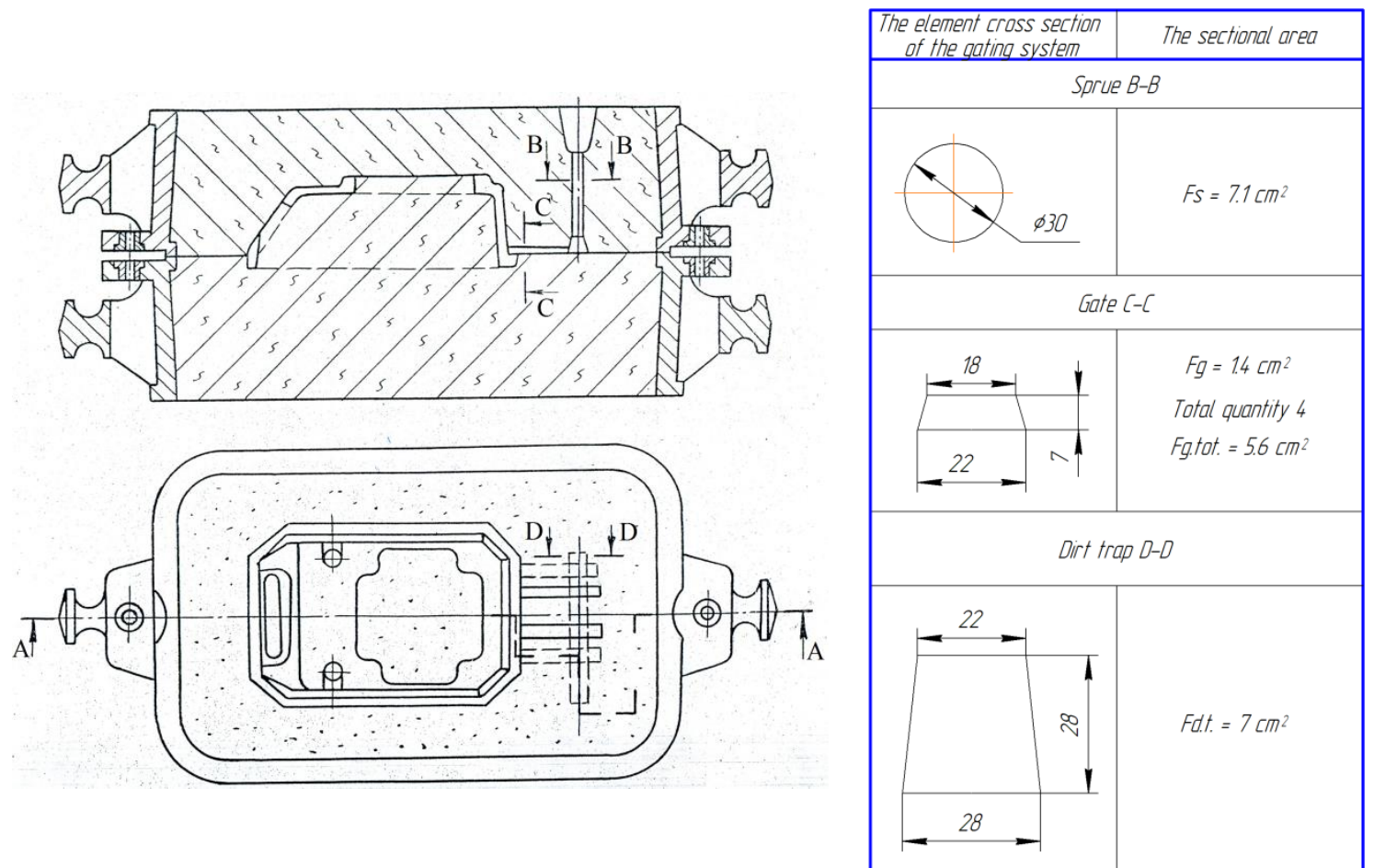

Figure 7 - The configuration of the sand mould and dimensions of the elements of the gating system. 


\begin{tabular}{|c|c|c|c|c|c|c|}
\hline Impact Factor: & $\begin{array}{l}\text { ISRA (India) } \\
\text { ISI (Dubai, UAE } \\
\text { GIF (Australia) } \\
\text { JIF }\end{array}$ & $\begin{array}{l}=1.344 \\
=0.829 \\
=0.564 \\
=1.500\end{array}$ & $\begin{array}{l}\text { SIS (USA) } \\
\text { PИНЦ (Russia) } \\
\text { ESJI (KZ) } \\
\text { SJIF (Morocco) }\end{array}$ & $\begin{array}{l}=0.912 \\
=0.234 \\
=\mathbf{3 . 8 6 0} \\
=\mathbf{2 . 0 3 1}\end{array}$ & $\begin{array}{l}\text { ICV (Poland) } \\
\text { PIF (India) } \\
\text { IBI (India) }\end{array}$ & $\begin{array}{l}=6.630 \\
=1.940 \\
=4.260\end{array}$ \\
\hline
\end{tabular}

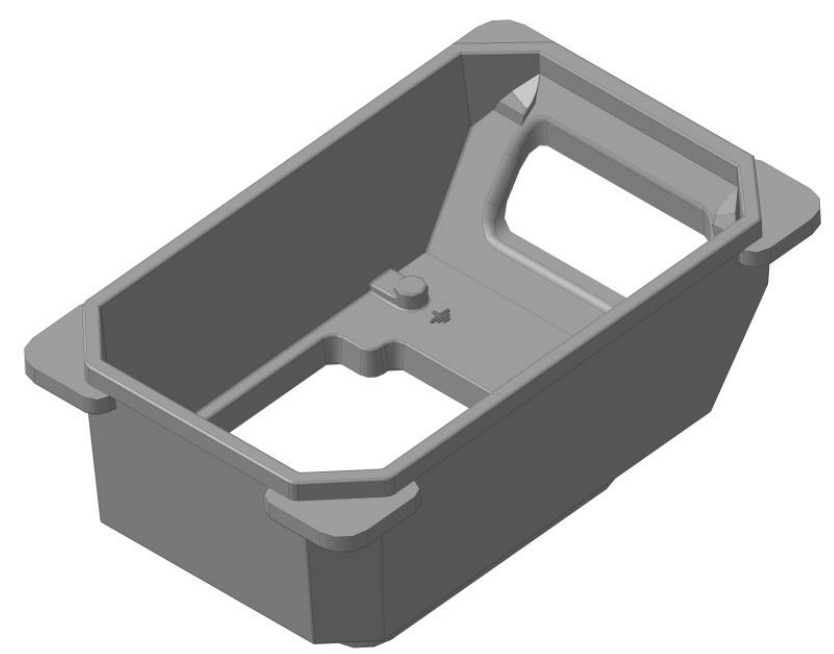

Figure 8 - The solid model of the casting (top view).

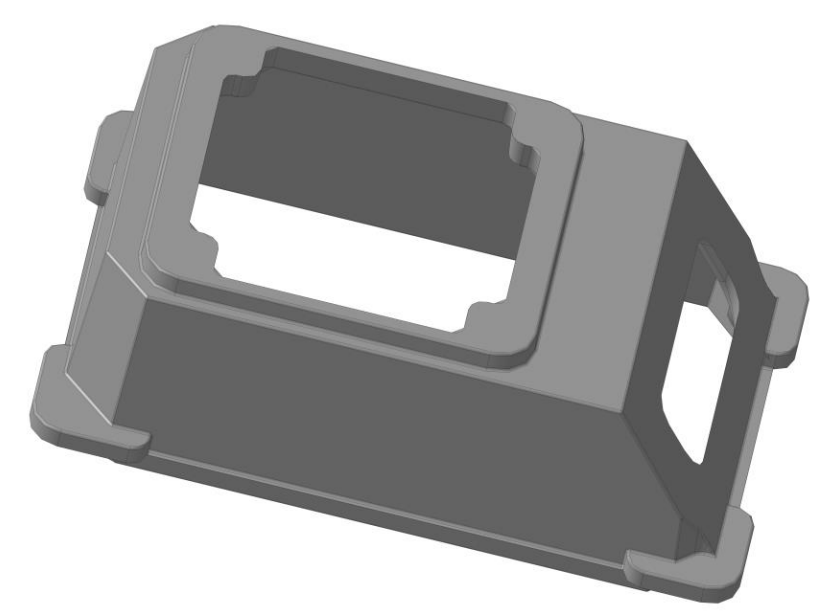

Figure 9 - The solid model of the casting (bottom view).

Table 3

The chemical composition of the alloy EN-GJL-150 in percentage.

\begin{tabular}{|c|c|c|c|c|c|c|c|}
\hline $\mathbf{F e}$ & $\mathbf{C}$ & $\mathbf{S i}$ & $\mathbf{M n}$ & $\mathbf{C r}$ & $\mathbf{P}$ & $\mathbf{S}$ & $\mathbf{~ N i}$ \\
\hline 92.85 & 3.6 & 2.2 & 0.7 & 0.15 & 0.2 & 0.15 & 0.15 \\
\hline
\end{tabular}

Phase transformations during cooling of melt are accompanied by the change of heat of crystallization, grain growth and nucleation/growth ratio.

Table 4

Thermophysical conditions of the casting process of grey cast iron.

\begin{tabular}{|c|c|c|c|}
\hline Liquid alloy & Austenite & Cementite & Graphite \\
\hline Heat of crystallization of the primary phase, $\mathrm{kJ} / \mathrm{kg}$ & \multicolumn{3}{|c|}{ Heat of crystallization, $\mathrm{kJ} / \mathrm{kg}$} \\
\hline 160 & 130 & 330 & 5900 \\
\hline CLF up, \% & \multicolumn{3}{|c|}{ Growth coefficient, $\mathrm{mm} /{ }^{\circ} \mathrm{C} \times \mathrm{s}$} \\
\hline 70 & 0.2 & 0.1 & 0.001 \\
\hline CLF down, $\%$ & \multicolumn{3}{|c|}{ Nucleation/growth ratio } \\
\hline 30 & 0.1 & 0.01 & 0.001 \\
\hline \multicolumn{4}{|c|}{ Total emissivity } \\
\hline 0.1 & 0.11 & 0.1 & 0.53 \\
\hline
\end{tabular}




\begin{tabular}{|c|c|c|c|c|c|c|}
\hline Impact Factor: & $\begin{array}{l}\text { ISRA (India) } \\
\text { ISI (Dubai, UAE } \\
\text { GIF (Australia) } \\
\text { JIF }\end{array}$ & $\begin{array}{l}=1.344 \\
=0.829 \\
=0.564 \\
=1.500\end{array}$ & $\begin{array}{l}\text { SIS (USA) } \\
\text { PИНЦ (Russia) } \\
\text { ESJI (KZ) } \\
\text { SJIF (Morocco) }\end{array}$ & $\begin{array}{l}=0.912 \\
=0.234 \\
=3.860 \\
=\mathbf{2 . 0 3 1}\end{array}$ & $\begin{array}{l}\text { ICV (Poland) } \\
\text { PIF (India) } \\
\text { IBI (India) }\end{array}$ & $\begin{array}{l}=6.630 \\
=1.940 \\
=4.260\end{array}$ \\
\hline
\end{tabular}

CLF up in percentage is the fraction of the liquid phase of the alloy. Free flow of melt is occurred up to $70 \%$.

CLF down in percentage is the critical fraction of the liquid phase of the alloy. Risering by melt between two liquid zones is impossible up to $30 \%$.

On the basis of the chemical composition of the alloy class and the basic constitution diagram «iron carbon» is built the modified constitution diagram «iron - carbon» [7]. According to the modified constitution diagram there are calculated the liquidus temperature and the solidus temperature, the parameters of phase equilibria, which are determined the phase transitions during the crystallization simulation of the alloy.

The temperature ranges for the liquid alloy, austenite, cementite and graphite during cooling of grey cast iron are presented on the modified constitution diagram «iron - carbon» (Fig. 10).

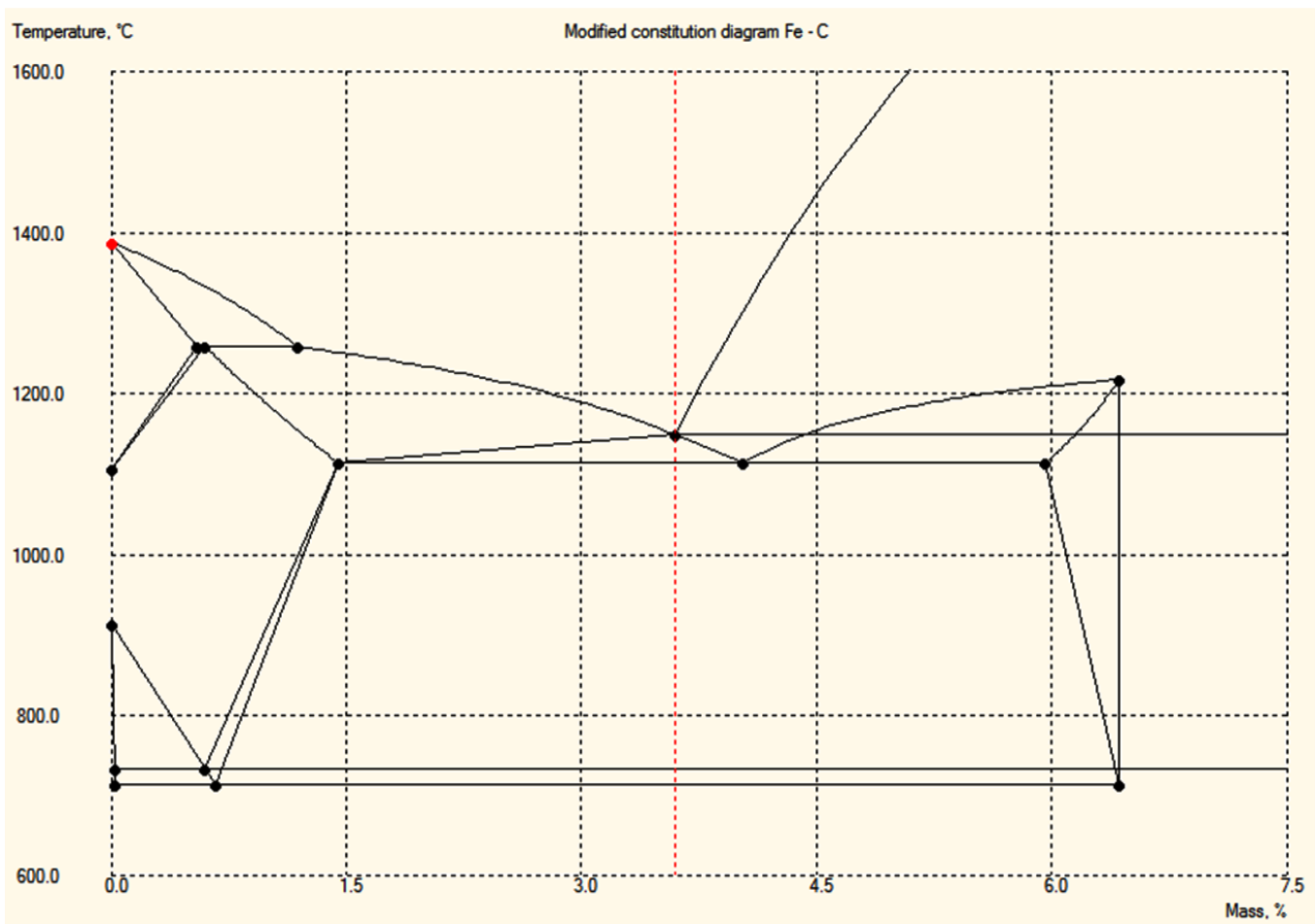

Figure 10 - The modified constitution diagram «iron - carbon».

The red dotted vertical line on the diagram is the concentration of the second main element of the alloy. In accordance with the modified constitution diagram «iron - carbon», gray cast iron is in the liquid state in the temperature range from 1150 to $1600{ }^{\circ} \mathrm{C}$. In the temperature range from 1150 to 1113 ${ }^{\circ} \mathrm{C}$ it is formed graphite eutectic. The saturation of austenite by carbon is occurred in the temperature range from 1150 to $732{ }^{\circ} \mathrm{C}$. Below of the temperature of $732{ }^{\circ} \mathrm{C}$ carbon is dissolved and graphite begins to reject from ferrite.
The values of density, heat conduction, specific heat and viscosity of gray cast iron were obtained by extrapolation. The blue dotted vertical line on the charts is the solidus temperature of the alloy, the green dotted vertical line is the temperature of the estimated kinetic solidus of the alloy. Properties change of grey cast iron during the temperature change is presented in Fig. $11-14$.

With decreasing of the temperature, density of the alloy increases slightly. The least density occurs in the graphite phase of the alloy, the highest is in the cementite phase. 


\begin{tabular}{l|lrl|l|ll} 
& ISRA (India) & $=\mathbf{1 . 3 4 4}$ & SIS (USA) & $=\mathbf{0 . 9 1 2}$ & ICV (Poland) & $=\mathbf{6 . 6 3 0}$ \\
Impact Factor: & ISI (Dubai, UAE) $=\mathbf{0 . 8 2 9}$ & PUHL (Russia) $=\mathbf{0 . 2 3 4}$ & PIF (India) & $=\mathbf{1 . 9 4 0}$ \\
& GIF (Australia) & $\mathbf{0 . 5 6 4}$ & ESJI (KZ) & $=3.860$ & IBI (India) & $=\mathbf{4 . 2 6 0}$ \\
& JIF & $\mathbf{1 . 5 0 0}$ & SJIF (Morocco) & $=\mathbf{2 . 0 3 1}$ & & \\
\hline
\end{tabular}

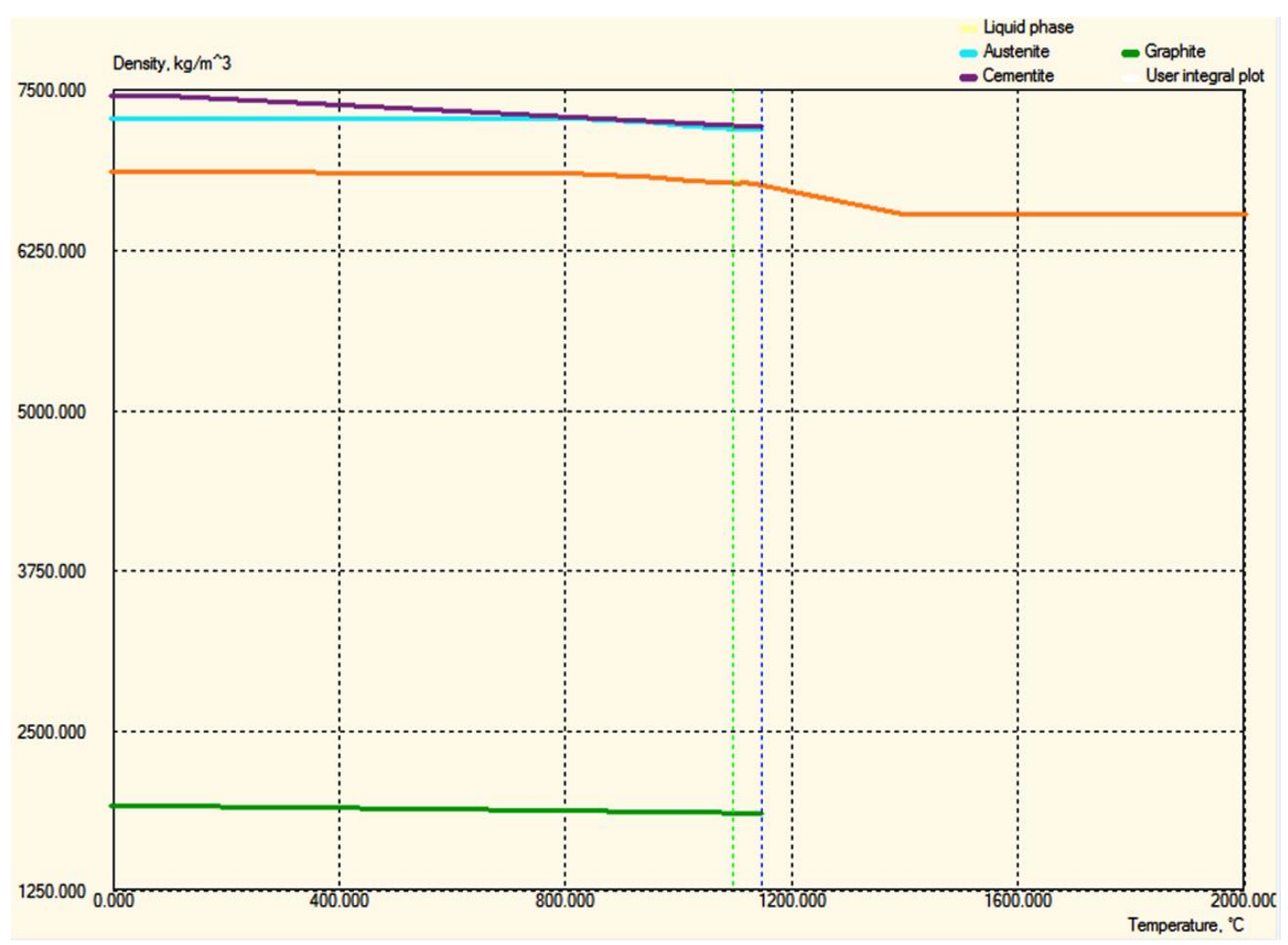

Figure 11 - Density during the change of the structural-phase state of gray cast iron.

In grey cast iron at the temperatures close to the equilibrium eutectic is observed preshrinkage expansion, for this reason the dependencies of density from the temperature for melt and for the solid phase must be formed so that density of melt near eutectic was higher than density of the solid phase.

Density calibration of the alloy was performed at setting of the following parameters: CEL (carbon equivalent) is $4.25 \%$, volume change of the casting material from the solidus temperature $\left(1137.49{ }^{\circ} \mathrm{C}\right)$ till the ambient temperature $\left(20{ }^{\circ} \mathrm{C}\right)$ is $1.12 \%$, the mould hardness $(+\mathrm{GF}+)$ is 80 , liquid shrinkage is $0.65 \frac{\%}{100^{\circ} \mathrm{C}}, \mathrm{T}_{\mathrm{P}}$ is $1600{ }^{\circ} \mathrm{C}$ (ATAS is a modular process control system for analyzing, optimizing and stabilizing the foundry process), $\mathrm{T}_{\text {Elow }}$ is $1147.49{ }^{\circ} \mathrm{C}$ (ATAS), GRF 2 is 25 , eutectic graphite is $6.5 \mathrm{~g}$, proeutectic is $20 \%$, eutectic 1 is $50 \%$, eutectic 2 is $30 \%$, primary austenite is $15 \%$.
The highest heat conduction has gray cast iron saturated by graphite. Cooling of the alloy from 1200 ${ }^{\circ} \mathrm{C}$ to $22{ }^{\circ} \mathrm{C}$ with formation of the graphite phase is characterized by increase of heat conduction in three times. The value of heat conduction in the cementite phase doesn't change and amounts about $20 \mathrm{~W} / \mathrm{m} \times$ ${ }^{\circ} \mathrm{C}$.

Simultaneously with increase of heat conduction in the graphite phase of the alloy, specific heat is decreased. In the cementite phase of grey cast iron, cooling occurs with constant expended energy.

The change of the value of viscosity of gray cast iron occurs above the solidus temperature, i.e. the alloy is in the liquid state. The decrease of viscosity of the alloy is observed in the temperature range from 2000 to $1300{ }^{\circ} \mathrm{C}$.

High-silica sand was used as the mould material. The dependencies of density, heat conduction and specific heat of the mould material from the temperature are presented in Fig. $15-17$. 


\begin{tabular}{|c|c|c|c|c|c|c|}
\hline Impact Factor: & $\begin{array}{l}\text { ISRA (India) } \\
\text { ISI (Dubai, UAF } \\
\text { GIF (Australia) } \\
\text { JIF }\end{array}$ & $\begin{array}{r}=1.344 \\
=0.829 \\
=0.564 \\
=1.500\end{array}$ & $\begin{array}{l}\text { SIS (USA) } \\
\text { PИНЦ (Russia) } \\
\text { ESJI (KZ) } \\
\text { SJIF (Morocco) }\end{array}$ & $\begin{array}{l}=0.912 \\
=0.234 \\
=3.860 \\
=\mathbf{2 . 0 3 1}\end{array}$ & $\begin{array}{l}\text { ICV (Poland) } \\
\text { PIF (India) } \\
\text { IBI (India) }\end{array}$ & $\begin{array}{l}=6.630 \\
=1.940 \\
=4.260\end{array}$ \\
\hline
\end{tabular}

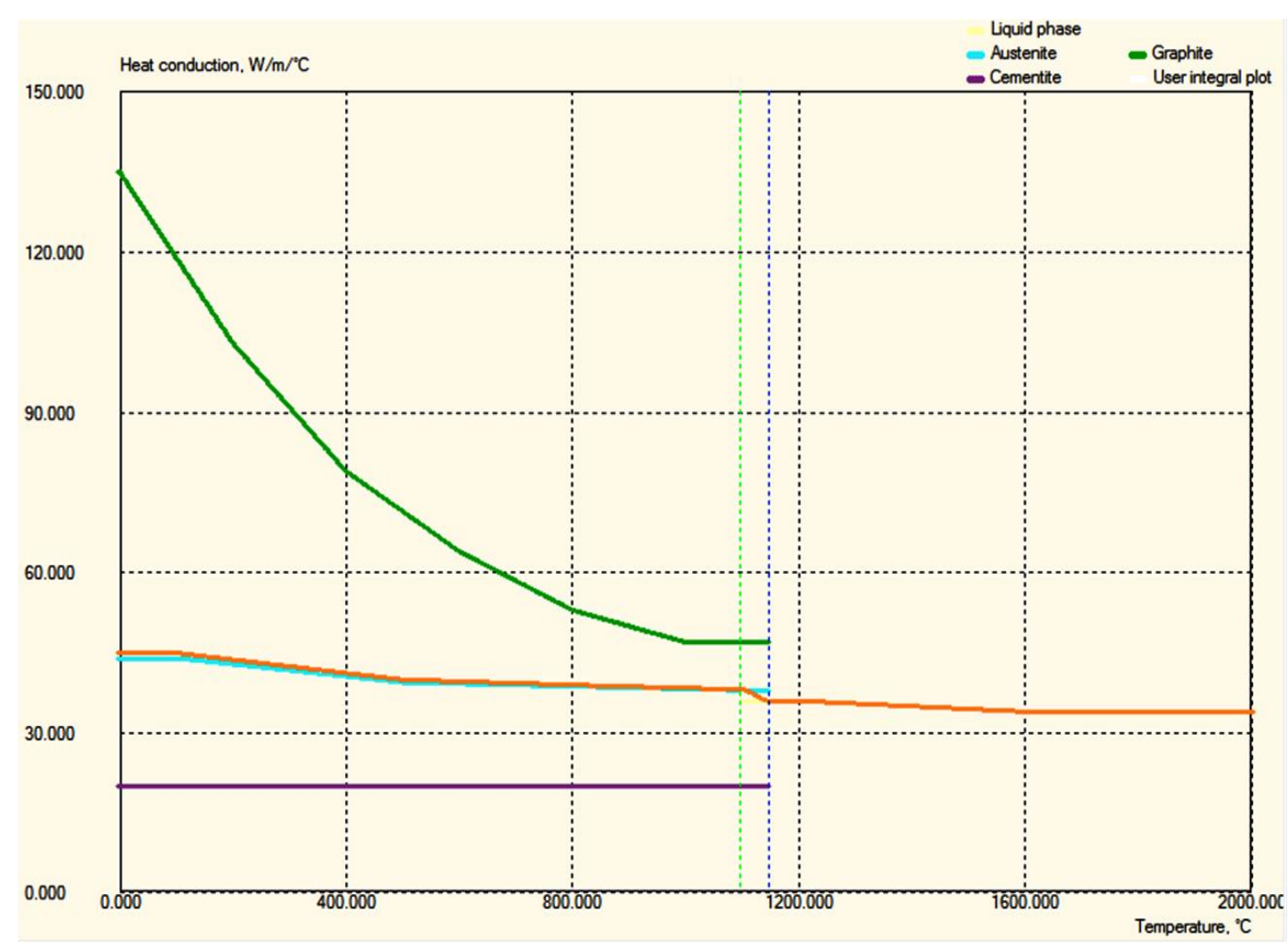

Figure 12 - Heat conduction during the change of the structural-phase state of gray cast iron.

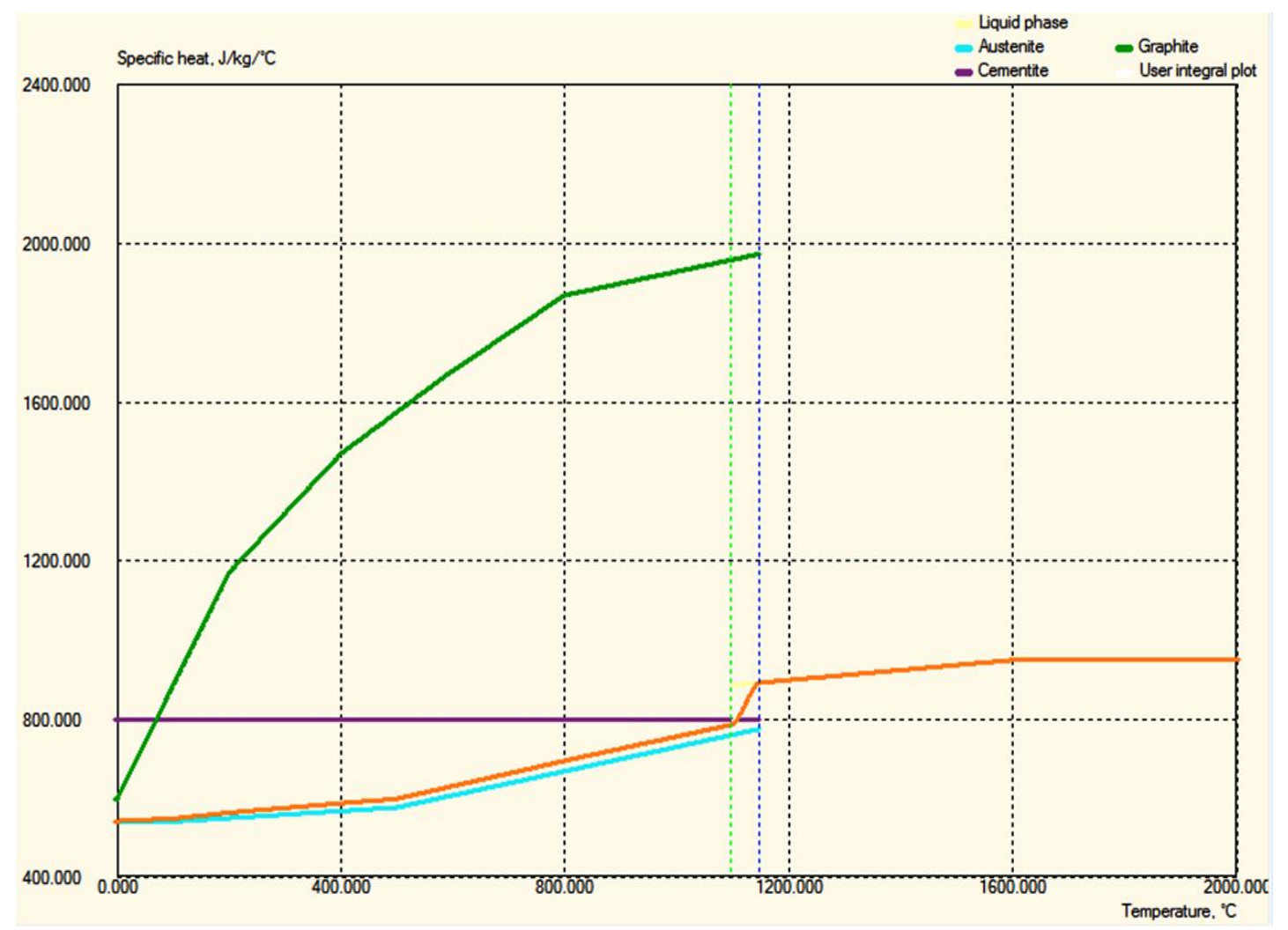

Figure 13 - Specific heat during the change of the structural-phase state of gray cast iron. 


\begin{tabular}{|c|c|c|c|c|c|c|}
\hline Impact Factor: & $\begin{array}{l}\text { ISRA (India) } \\
\text { ISI (Dubai, UAE } \\
\text { GIF (Australia) } \\
\text { JIF }\end{array}$ & $\begin{array}{l}=1.344 \\
=0.829 \\
=0.564 \\
=1.500\end{array}$ & $\begin{array}{l}\text { SIS (USA) } \\
\text { PИНЦ (Russia) } \\
\text { ESJI (KZ) } \\
\text { SJIF (Morocco) }\end{array}$ & $\begin{array}{l}=0.912 \\
=0.234 \\
=\mathbf{3 . 8 6 0} \\
=\mathbf{2 . 0 3 1}\end{array}$ & $\begin{array}{l}\text { ICV (Poland) } \\
\text { PIF (India) } \\
\text { IBI (India) }\end{array}$ & $\begin{array}{l}=6.630 \\
=1.940 \\
=4.260\end{array}$ \\
\hline
\end{tabular}

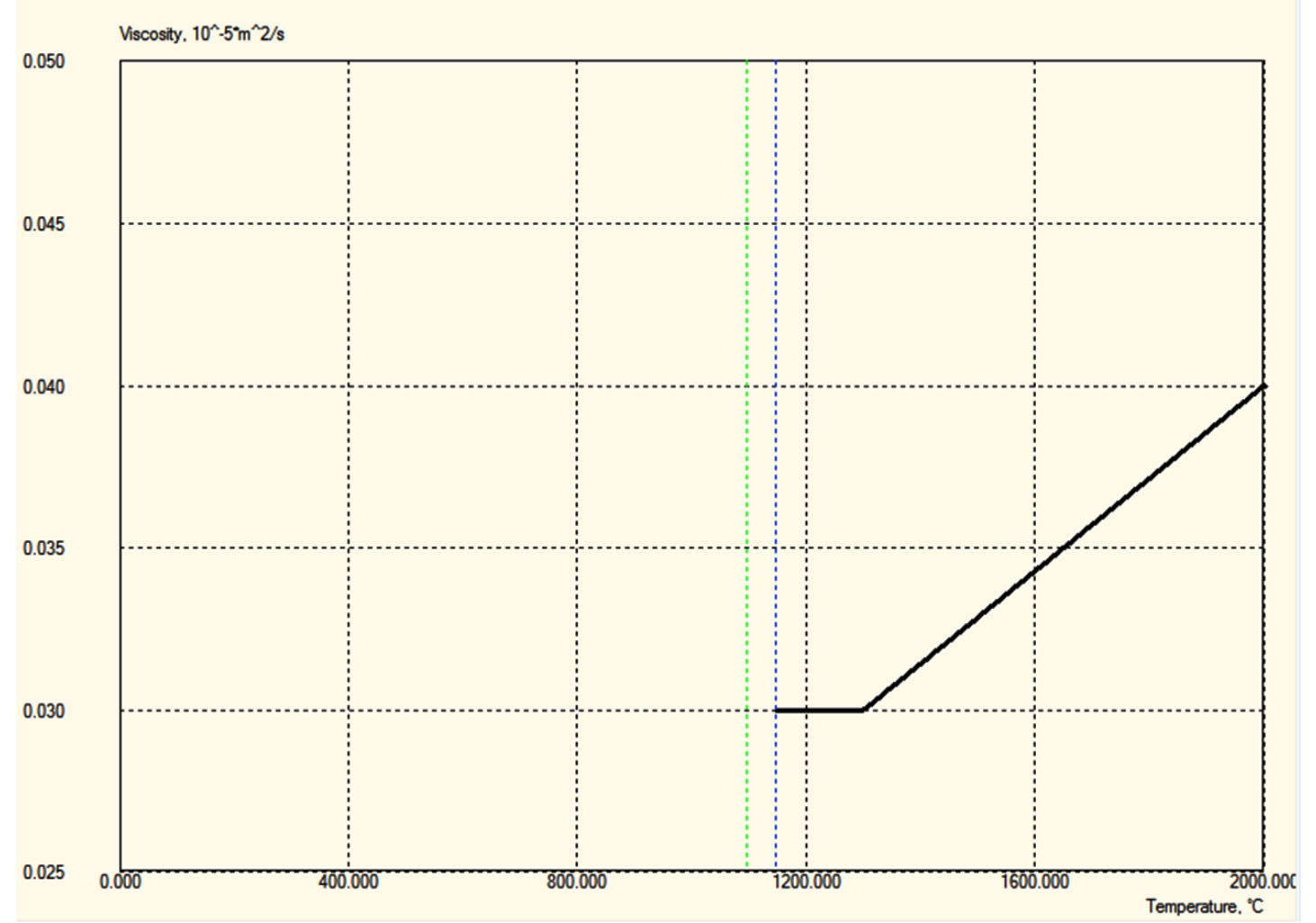

Figure 14 - Viscosity of gray cast iron during the change of the temperature.

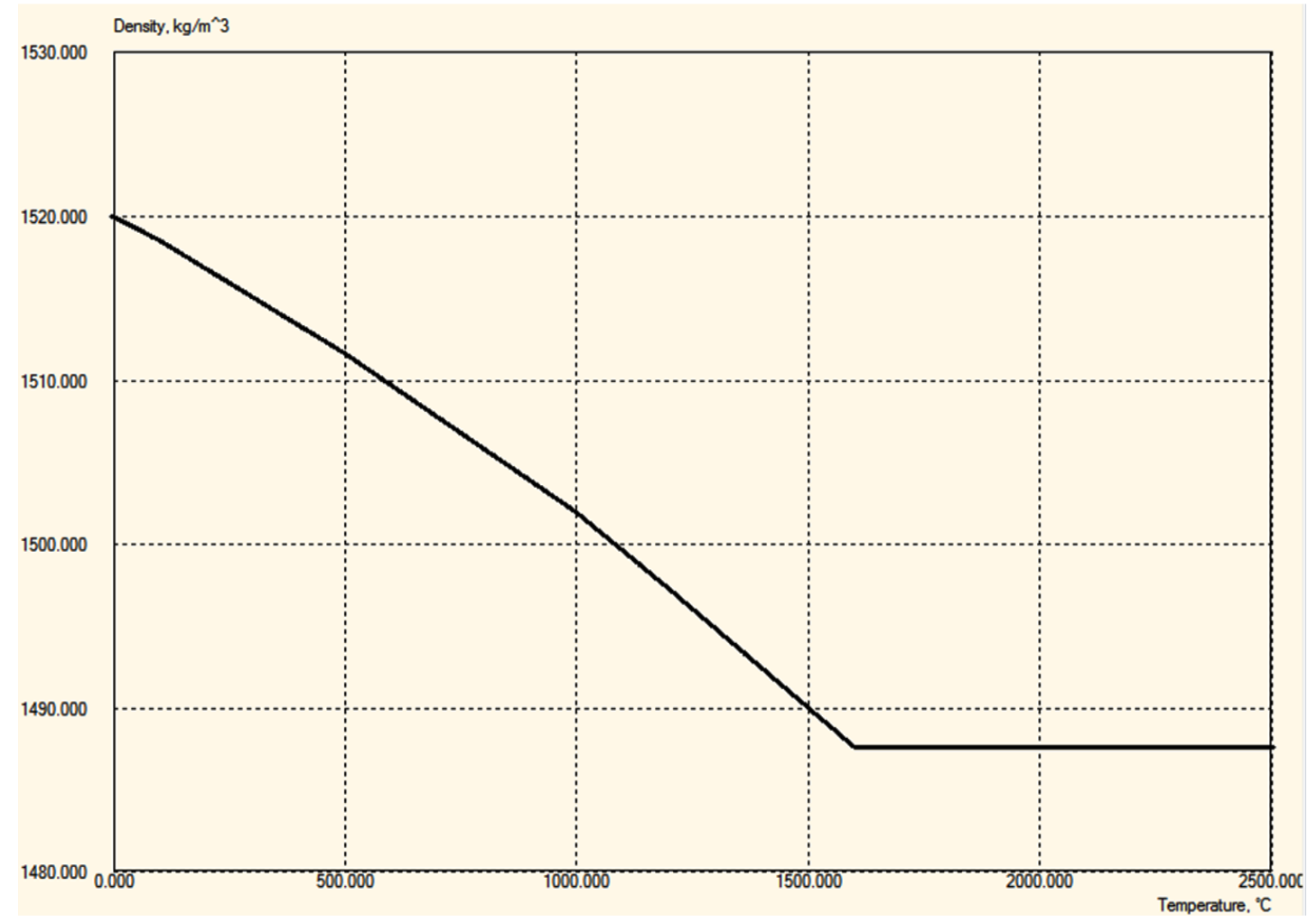

Figure 15 - The change of density of the mould material (high-silica sand) from the temperature. 


\begin{tabular}{|c|c|c|c|c|c|c|}
\hline Impact Factor: & $\begin{array}{l}\text { ISRA (India) } \\
\text { ISI (Dubai, UAE } \\
\text { GIF (Australia) } \\
\text { JIF }\end{array}$ & $\begin{array}{r}=1.344 \\
=0.829 \\
=0.564 \\
=1.500\end{array}$ & $\begin{array}{l}\text { SIS (USA) } \\
\text { PИНЦ (Russia) } \\
\text { ESJI (KZ) } \\
\text { SJIF (Morocco) }\end{array}$ & $\begin{array}{l}=0.912 \\
=0.234 \\
=\mathbf{3 . 8 6 0} \\
=\mathbf{2 . 0 3 1}\end{array}$ & $\begin{array}{l}\text { ICV (Poland) } \\
\text { PIF (India) } \\
\text { IBI (India) }\end{array}$ & $\begin{array}{l}=6.630 \\
=1.940 \\
=4.260\end{array}$ \\
\hline
\end{tabular}

Density of high-silica sand at the ambient temperature is $1519.5 \mathrm{~kg} / \mathrm{m}^{3}$. After filling of the mould by melt it is observed the decrease of density of the some volume of high-silica sand up to 1487.5 $\mathrm{kg} / \mathrm{m}^{3}$ at the temperature of $1600{ }^{\circ} \mathrm{C}$. Change rate of density of high-silica sand in the crystallization phase is the least.

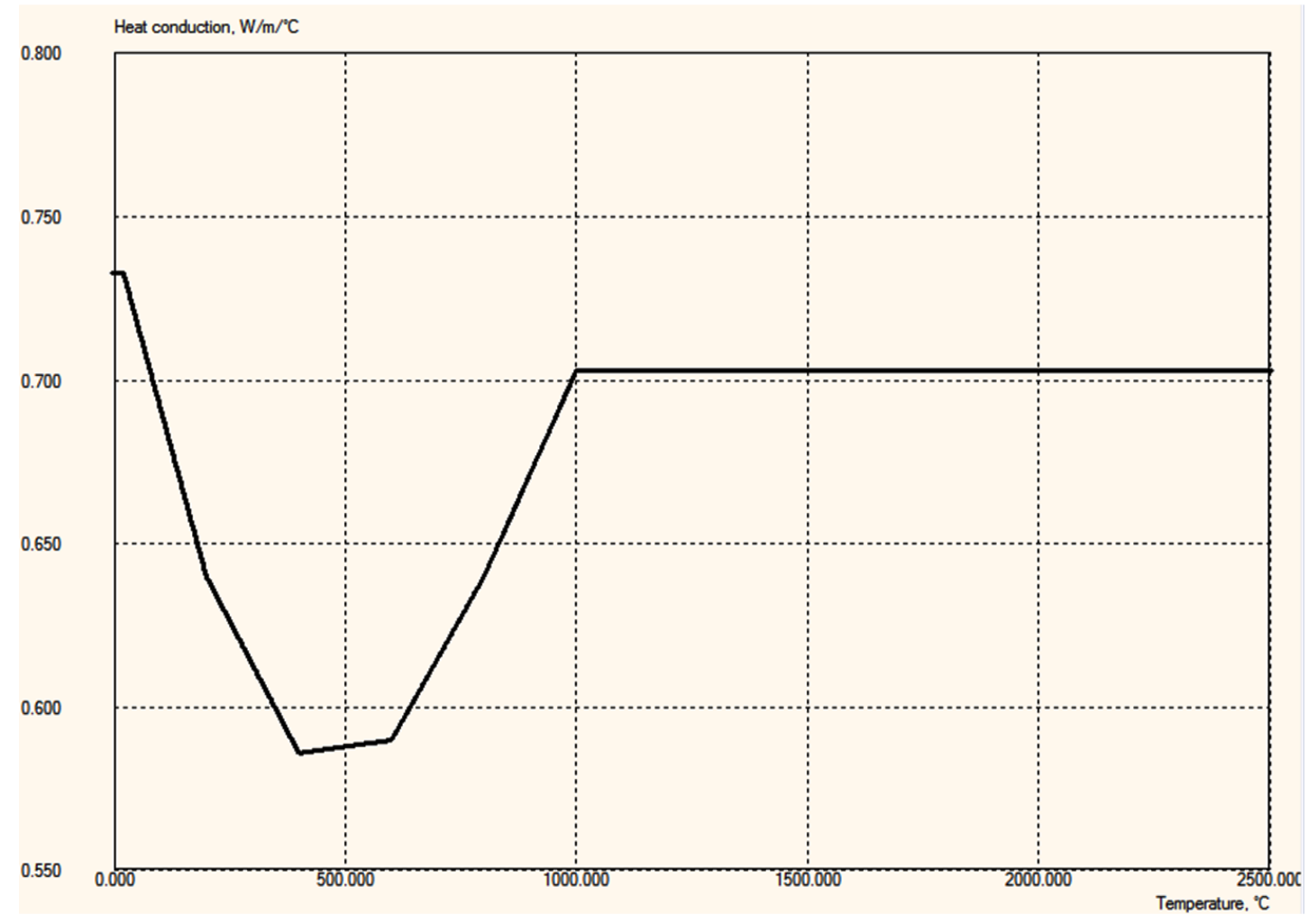

Figure 16 - The change of heat conduction of the mould material (high-silica sand) from the temperature.

The decrease and the subsequent increase of heat conduction of high-silica sand during cooling of gray cast iron occur after the solidus temperature.
The maximal value of heat conduction of the mould material at the temperature of $22{ }^{\circ} \mathrm{C}$ is $0.732 \mathrm{~W} / \mathrm{m} \times$ ${ }^{\circ} \mathrm{C}$. 


\begin{tabular}{l|lrl|l|ll} 
& ISRA (India) & $=\mathbf{1 . 3 4 4}$ & SIS (USA) & $=\mathbf{0 . 9 1 2}$ & ICV (Poland) & $=\mathbf{6 . 6 3 0}$ \\
Impact Factor: & ISI (Dubai, UAE) $=\mathbf{0 . 8 2 9}$ & PUHL (Russia) $=\mathbf{0 . 2 3 4}$ & PIF (India) & $=\mathbf{1 . 9 4 0}$ \\
& GIF (Australia) & $\mathbf{0 . 5 6 4}$ & ESJI (KZ) & $=3.860$ & IBI (India) & $=\mathbf{4 . 2 6 0}$ \\
& JIF & $\mathbf{1 . 5 0 0}$ & SJIF (Morocco) & $=\mathbf{2 . 0 3 1}$ & & \\
\hline
\end{tabular}

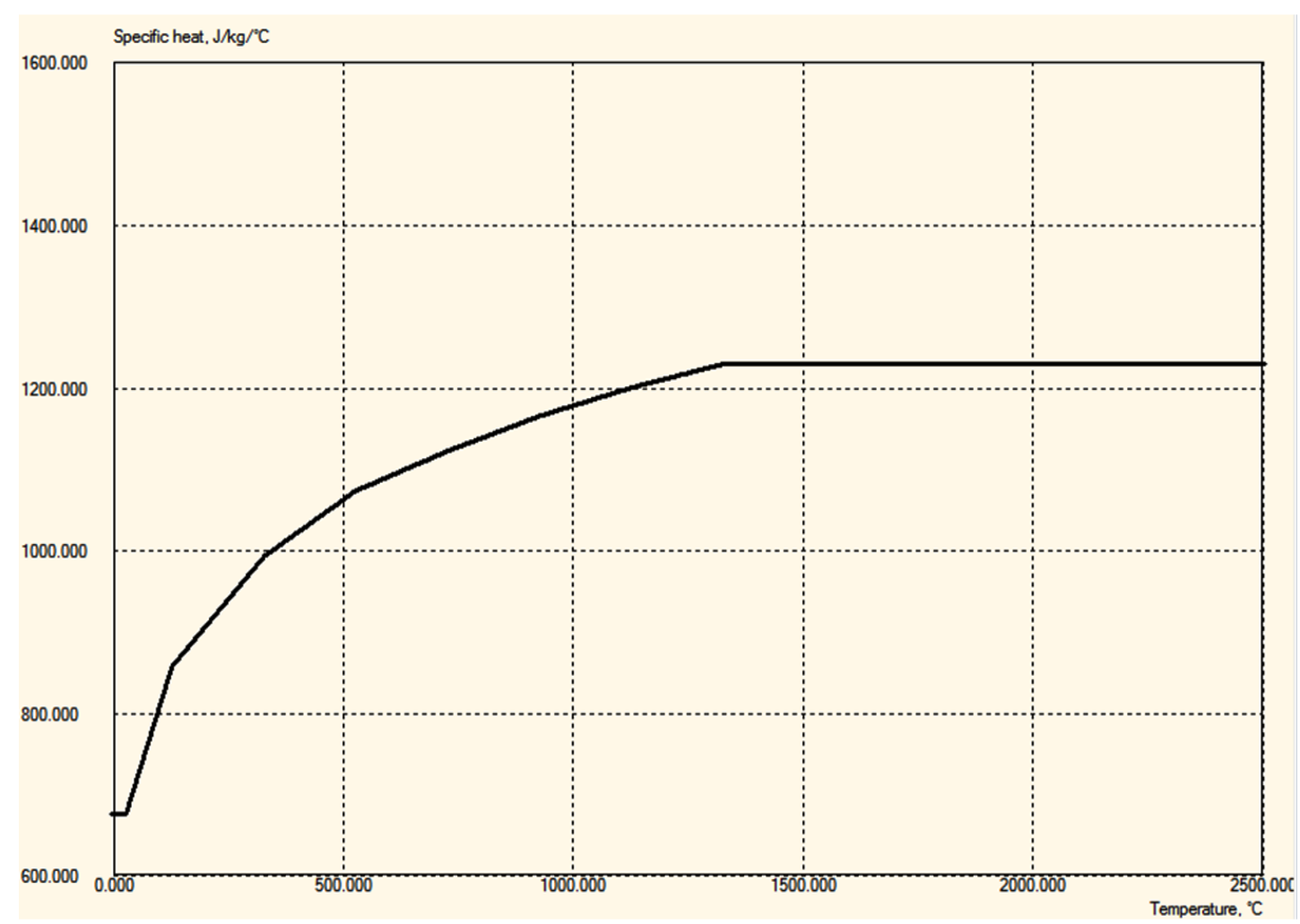

Figure 17 - The change of specific heat of the mould material (high-silica sand) from the temperature.

The decrease in two times of the value of quantity of heat during cooling of the mould material occurs in the temperature range from 1319 to $22{ }^{\circ} \mathrm{C}$.

The main properties of the mould material were taken total emissivity, gas-permeability and rigidity.
The set value of gas-permeability it is necessary during the process simulation of the mould filling by melt given of gas (from the mould cavity). The values of these parameters are shown in table 5.

The properties of the mould material.

Table 5

\begin{tabular}{|c|c|}
\hline Parameter & Value \\
\hline Total emissivity & 0.93 \\
\hline Gas-permeability & $1.53 \times 10^{-6} \mathrm{~m}^{2} / \mathrm{Pa} \times \mathrm{s}$ \\
\hline Rigidity & 1 \\
\hline
\end{tabular}

The created solid model was saved in a file with STL extension for the subsequent import to the program LVMFlow [8]. Into the module «3D Import» it was provided the information about the dimensions of the model and the number of the faces (16562). The number of the faces is set by Step accuracy (1). The model was oriented in the space in accordance with the technological process of casting. Fixation of the model was carried out during pressing of the buttons «Align» for 3 axes.

The fixed model of the casting is presented in Fig. 18. 


\begin{tabular}{l|lrl|l|ll} 
& ISRA (India) & $=\mathbf{1 . 3 4 4}$ & SIS (USA) & $=\mathbf{0 . 9 1 2}$ & ICV (Poland) & $=\mathbf{6 . 6 3 0}$ \\
Impact Factor: & ISI (Dubai, UAE) $=\mathbf{0 . 8 2 9}$ & PUHU (Russia) $=\mathbf{0 . 2 3 4}$ & PIF (India) & $=\mathbf{1 . 9 4 0}$ \\
& GIF (Australia) & $\mathbf{0 . 5 6 4}$ & ESJI (KZ) & $=\mathbf{3 . 8 6 0}$ & IBI (India) & $\mathbf{4 . 2 6 0}$
\end{tabular}

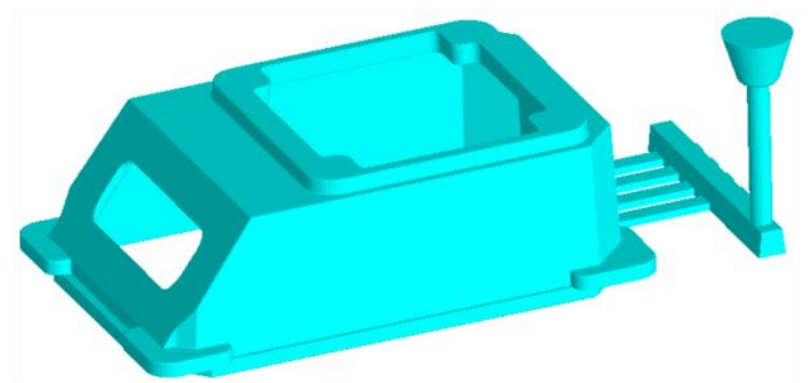

Figure 18 - The uploaded casting and the gating system into the module «3D Import».

After determining of the orientation and fixing of the model, the appropriate information was saved in a file with CVG extension. This file was imported into the module «Initial settings».

For the reduction of the calculation time, the gated pattern was created incompletely. The model casting was inscribed in the calculated field. The dimensions of the field: $693.878 \mathrm{~mm}$ (X-axis), $383.16 \mathrm{~mm}$ (Y-axis) and $275.978 \mathrm{~mm}$ (Z-axis). The position of the model casting in the calculated field according to the corresponding coordinate axes is $346.939 \mathrm{~mm}, 191.58 \mathrm{~mm}$ and $137.375 \mathrm{~mm}$. The dimension of a cell was adopted by the value of $5.307 \mathrm{~mm}$ (the number of the cells along $\mathrm{X}$-axis was 131, along Y-axis was 72 and along Z-axis was 52). After generating of a mesh, the total number of the cells was 490464, the casting cells was 41810 . For the calculation it was required amount of memory of 413.5 Mb. The lower and higher thickness of the mould according to the coordinate axes was set to the default by the value of $10 \mathrm{~mm}$. The ambient temperature didn't differ from the initial temperature of the mould.

The generated mesh is presented in Fig. 19.

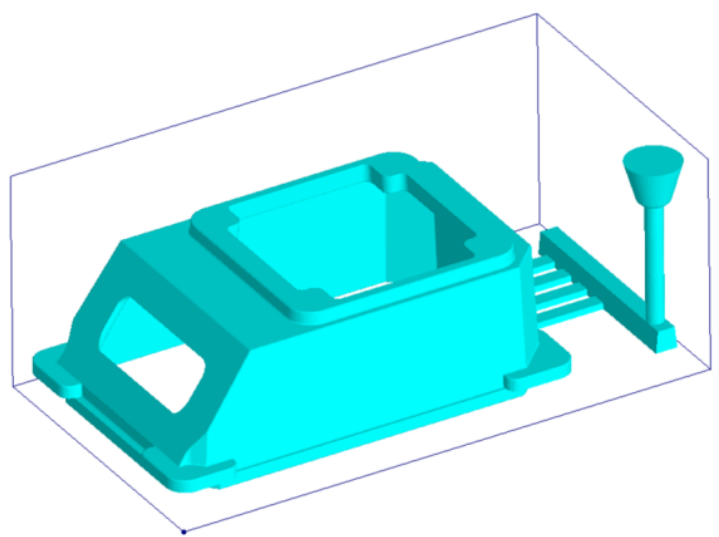

Figure 19 - The mesh creation.

For the alloy it was set the initial temperature of $1325^{\circ} \mathrm{C}$, the liquidus temperature is $1147.608^{\circ} \mathrm{C}$ and the solidus temperature is $1147.495{ }^{\circ} \mathrm{C}$. CLF Niyama was adopted of $3 \%[9 ; 10]$. The calculated volume of the alloy in the sand mould was amounted to $3964.747 \mathrm{~cm}^{3}$, the calculated mass of the casting was amounted to $26.169 \mathrm{~kg}$.

The initial temperature of the mould material was taken of $20{ }^{\circ} \mathrm{C}$. The calculated volume of highsilica sand was amounted to $69354.921 \mathrm{~cm}^{3}$, the calculated mass of the mould material was amounted to $105.399 \mathrm{~kg}$.
The mould cavity was filled by air (at the initial temperature of $20^{\circ} \mathrm{C}$ and radiolucency of 1.0).

The contact gap was absent. Upper, lateral and lower coefficients, taking into account the contact properties respectively of top, side and bottom surfaces of the sand mould, were taken of $100 \%$. The coefficients are used for the fit of forming the air gaps.

The calculated field with the display of the casting material, the mould material and the cavity medium is presented in Fig. 20. 


\begin{tabular}{|c|c|c|c|c|c|c|}
\hline Impact Factor: & $\begin{array}{l}\text { ISRA (India) } \\
\text { ISI (Dubai, UAE } \\
\text { GIF (Australia) } \\
\text { JIF }\end{array}$ & $\begin{array}{l}=1.344 \\
=0.829 \\
=0.564 \\
=1.500\end{array}$ & $\begin{array}{l}\text { SIS (USA) } \\
\text { PИНЦ (Russia) } \\
\text { ESJI (KZ) } \\
\text { SJIF (Morocco) }\end{array}$ & $\begin{array}{l}=0.912 \\
=0.234 \\
=\mathbf{3 . 8 6 0} \\
=\mathbf{2 . 0 3 1}\end{array}$ & $\begin{array}{l}\text { ICV (Poland) } \\
\text { PIF (India) } \\
\text { IBI (India) }\end{array}$ & $\begin{array}{l}=6.630 \\
=1.940 \\
=4.260\end{array}$ \\
\hline
\end{tabular}

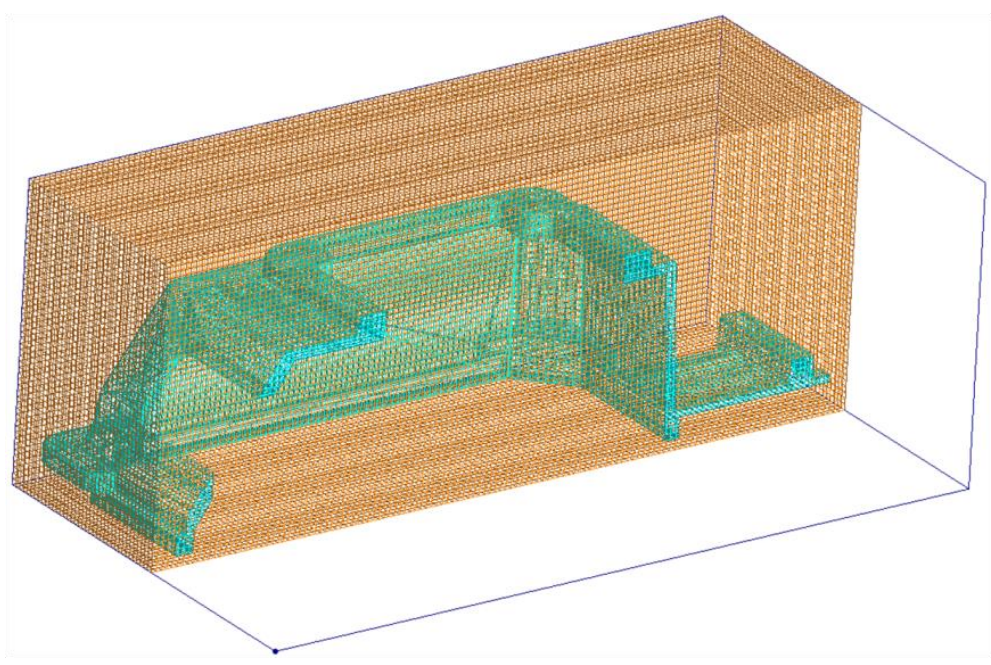

Figure 20 - The calculated field with the display of the casting material, the mould material and the cavity medium.

In the cross section of the pouring basin (XY plane) it was set one gating point. The coordinates of the gating point and direction of melt flow are presented in Fig. 21.

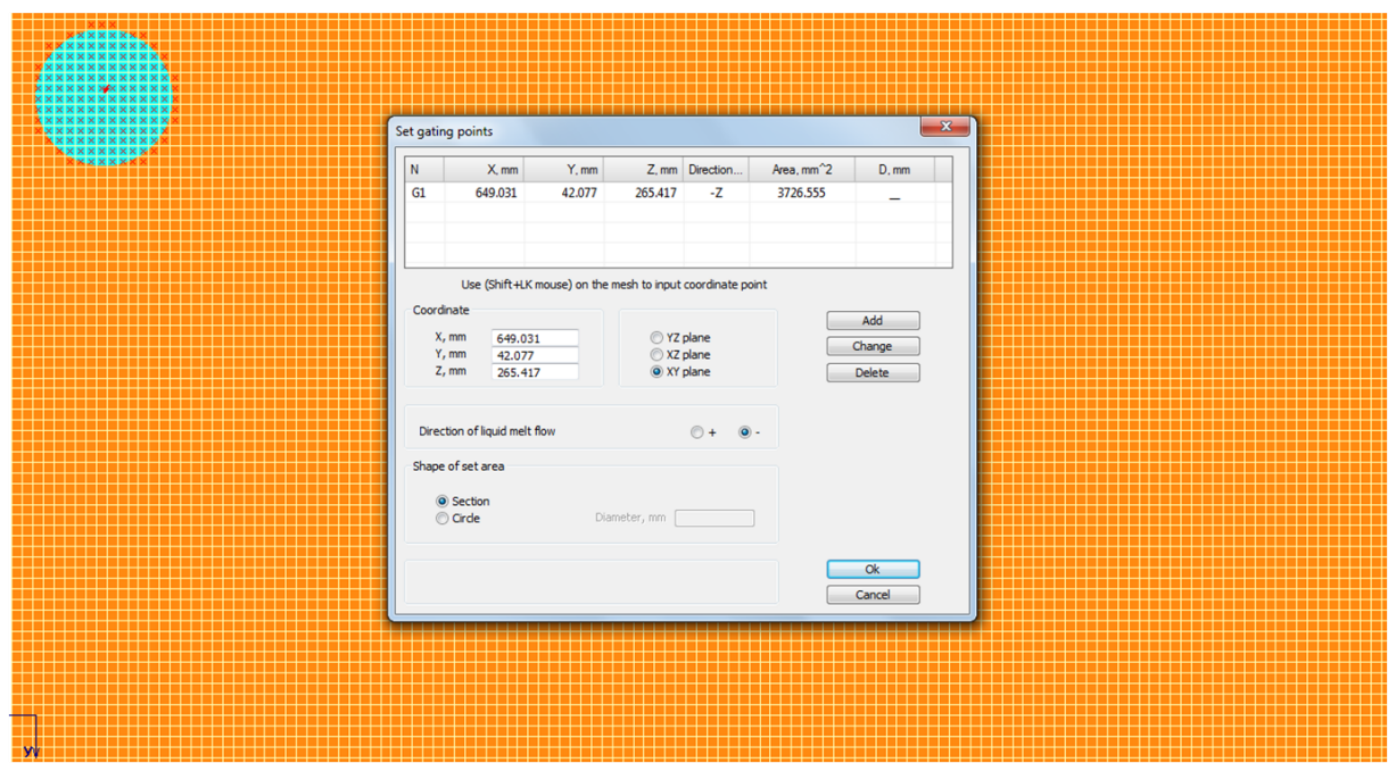

Figure 21 - The set of the gating point.

For measuring of flow of the poured alloy it was set the flowmeter. The dialog window with coordinates of the location of the flowmeter is presented in Fig. 22. The calculation of flow was carried out on the plane of setting of the gating point. 


\begin{tabular}{|c|c|c|c|c|c|c|}
\hline Impact Factor: & $\begin{array}{l}\text { ISRA (India) } \\
\text { ISI (Dubai, UAE } \\
\text { GIF (Australia) } \\
\text { JIF }\end{array}$ & $\begin{array}{l}=1.344 \\
=0.829 \\
=0.564 \\
=1.500\end{array}$ & $\begin{array}{l}\text { SIS (USA) } \\
\text { PИНЦ (Russia) } \\
\text { ESJI (KZ) } \\
\text { SJIF (Morocco) }\end{array}$ & $\begin{array}{l}=0.912 \\
=0.234 \\
=\mathbf{3 . 8 6 0} \\
=\mathbf{2 . 0 3 1}\end{array}$ & $\begin{array}{l}\text { ICV (Poland) } \\
\text { PIF (India) } \\
\text { IBI (India) }\end{array}$ & $\begin{array}{l}=6.630 \\
=1.940 \\
=4.260\end{array}$ \\
\hline
\end{tabular}

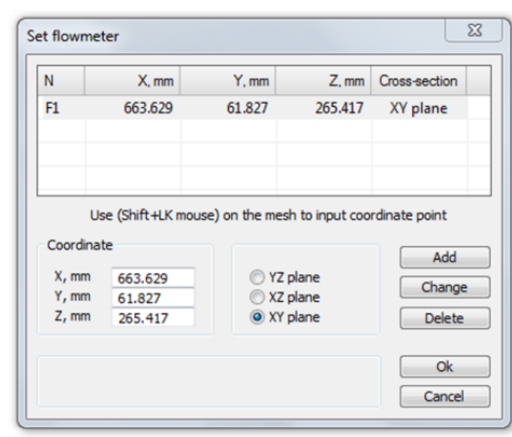

Figure 22 - The set of the flowmeter.

By means of the sensors it is possible to control the change of the some parameters of the casting process. The location of six sensors in the mould cavity is presented in Fig. 23.

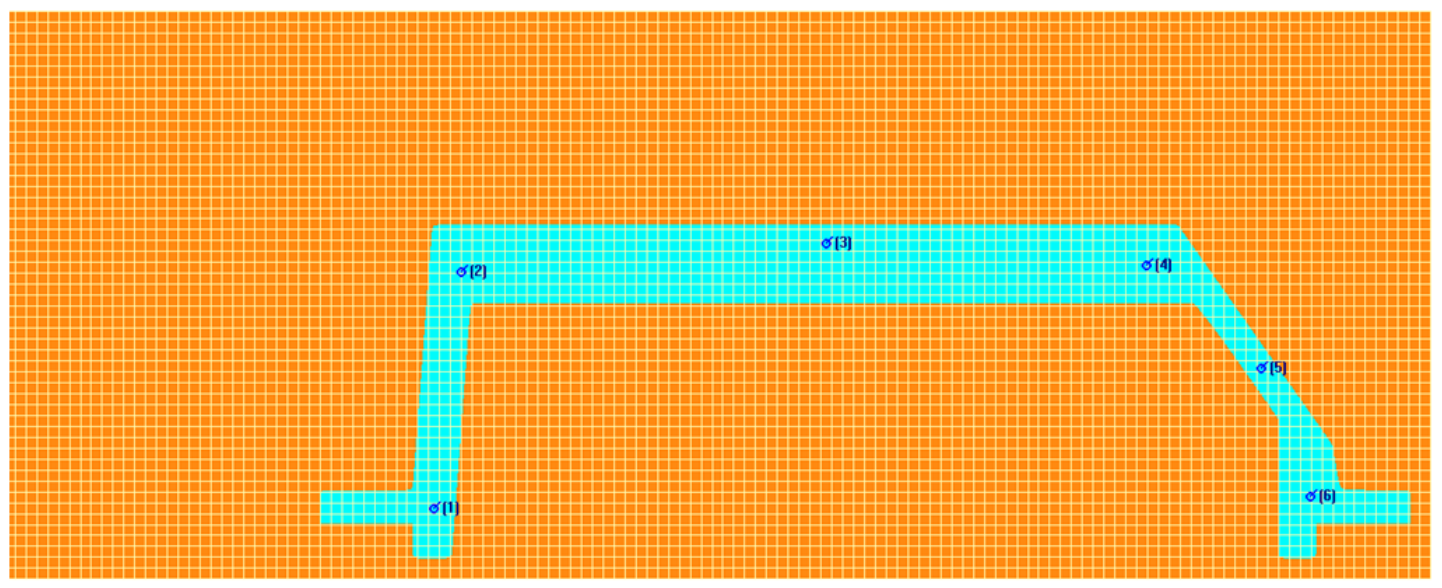

Figure 23 - The set of the sensors.

In the dialog window «Filling parameters» it was set the pouring type - lip pouring. The section area of the gate was amounted to $3726.555 \mathrm{~mm}^{2}$. Effective pressure head (used for the calculation of initial metal flow through the cross section of the gating system), where it is set the gating point, is called by pressure height. In the dialog window, pressure height $\mathrm{PH}$ by the dimension of $85.254 \mathrm{~mm}$ will be the distance from which the filling process occurs. 


\begin{tabular}{|c|c|c|c|c|c|c|}
\hline Impact Factor: & $\begin{array}{l}\text { ISRA (India) } \\
\text { ISI (Dubai, UAE } \\
\text { GIF (Australia) } \\
\text { JIF }\end{array}$ & $\begin{array}{l}=1.344 \\
=0.829 \\
=0.564 \\
=1.500\end{array}$ & $\begin{array}{l}\text { SIS (USA) } \\
\text { PUHЦ (Russia) } \\
\text { ESJI (KZ) } \\
\text { SJIF (Morocco) }\end{array}$ & $\begin{array}{l}=0.912 \\
=0.234 \\
=\mathbf{3 . 8 6 0} \\
=\mathbf{2 . 0 3 1}\end{array}$ & $\begin{array}{l}\text { ICV (Poland) } \\
\text { PIF (India) } \\
\text { IBI (India) }\end{array}$ & $\begin{array}{l}=6.630 \\
=1.940 \\
=4.260\end{array}$ \\
\hline
\end{tabular}

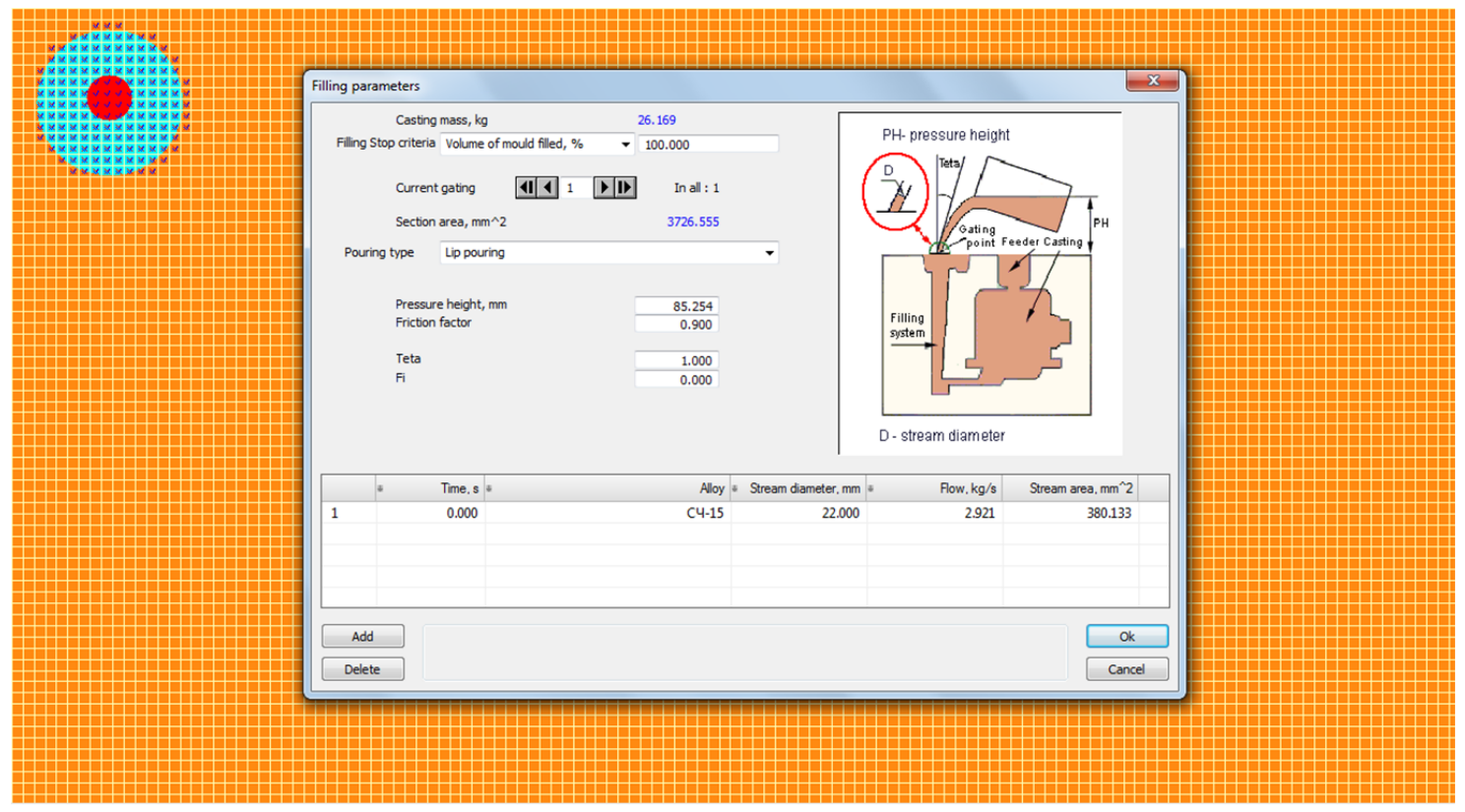

Figure 24 - The filling parameters of the sand mould by melt.

The friction factor characterizes the resistance in the gating system. The friction factor was taken of 0.9. The projection angle of the stream of metal on the plane with $\mathrm{X}$-axis (Teta) was taken by the value of $1^{\circ}$. The stream diameter $(22 \mathrm{~mm})$ of melt was set given of the dimensions of the sprue (in the cross section it is displayed by the red color). The values of the stream area and melt flow are calculated automatically and are amounted to $380.133 \mathrm{~mm}^{2}$ and
$2.921 \mathrm{~kg} / \mathrm{s}$ respectively. The established filling parameters of the sand mould by melt are presented in Fig. 24.

The information with the initial settings was saved in a file with SIM extension. The descriptor (a file with PSP extension) was created automatically.

The simulation parameters are presented in table 6.

Table 6

\section{The simulation parameters.}

\begin{tabular}{|c|c|}
\hline Type of cycling & Without cycling \\
\hline Calculation model & $\begin{array}{c}\text { Quasi-equilibrium, without segregation, without taking gas into account at filling, } \\
\text { without convection. }\end{array}$ \\
\hline Coefficient of turbulence & Aggressive AMG, The Gauss-Seidel method [11] \\
\hline Gravity influence coefficient, \% & 50 (medium gravity) \\
\hline Interfacial heat transfer model & Air gap \\
\hline Number of start up thread & 4 \\
\hline $\begin{array}{c}\text { Physical properties for } \\
\text { simulation }\end{array}$ & Calculated by phases \\
\hline Ratio volume/surface area, $\%$ & 1 \\
\hline Maximal step for solid, $\mathbf{s}$ & 7.98 \\
\hline Filling stop criteria & Volume of mould filled 100 \% \\
\hline Time intervals, $\mathbf{s}$ & From 0 to 100, step 10 \\
\hline Filed volume intervals, $\%$ & From 0 to 100, step 10 \\
\hline Liquid phase intervals, $\%$ & From 100 to 80, step 5 \\
\hline $\begin{array}{c}\text { Maximum temperature } \\
\text { intervals, }{ }^{\circ} \mathbf{C}\end{array}$ & From 1500 to 20, step 100 \\
\hline
\end{tabular}




\begin{tabular}{|c|c|c|c|c|c|c|}
\hline Impact Factor: & $\begin{array}{l}\text { ISRA (India) } \\
\text { ISI (Dubai, UAE } \\
\text { GIF (Australia) } \\
\text { JIF }\end{array}$ & $\begin{array}{l}=1.344 \\
=0.829 \\
=0.564 \\
=1.500\end{array}$ & $\begin{array}{l}\text { SIS (USA) } \\
\text { PИНЦ (Russia) } \\
\text { ESJI (KZ) } \\
\text { SJIF (Morocco) }\end{array}$ & $\begin{array}{l}=0.912 \\
=0.234 \\
=3.860 \\
=2.031\end{array}$ & $\begin{array}{l}\text { ICV (Poland) } \\
\text { PIF (India) } \\
\text { IBI (India) }\end{array}$ & $\begin{array}{l}=6.630 \\
=1.940 \\
=4.260\end{array}$ \\
\hline
\end{tabular}

The wire model of the casting and the gating system in Fig. 25 are the channels for filling of melt. The calculation time of the casting process was amounted to 2010 seconds.

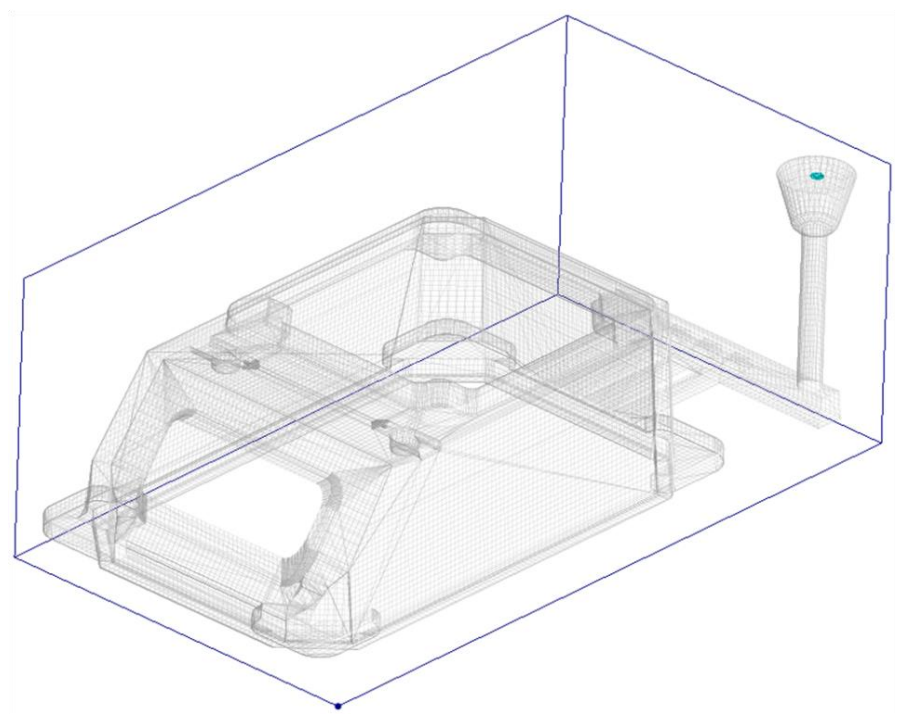

Figure 25 - The wire model of the casting and the gating system before the calculation process.

\section{Results and discussion}

The work [12] presents the analysis of the solidification process of non-alloy cast steel with the different wall thickness of the casting. On the basis of the derived dependence it was received the coefficient for definition of the solidification time of the casting.

The results of this research are the calculated fields on the model of the iron casting, characterizing the change of the casting parameters in the sand mould in accordance with the color scale. The simulation of the casting process in the sand mould of the case-shaped casting is described in the work [13].

The calculated fields of the temperature change of melt during the mould filling and subsequent cooling are presented in table 7.

The calculated time of the mould filling by melt was amounted to $9.106 \mathrm{~s}$. The calculated time of cooling (solidification) of melt in the sand mould was amounted to $396.185 \mathrm{~s}$. The total time of casting in the sand mould was amounted to $405.291 \mathrm{~s}$. The step of storing of the calculated field for the mould filling by melt was amounted to $0.9 \mathrm{~s}$.

\section{The temperature of melt (filling and cooling).}

Table 7

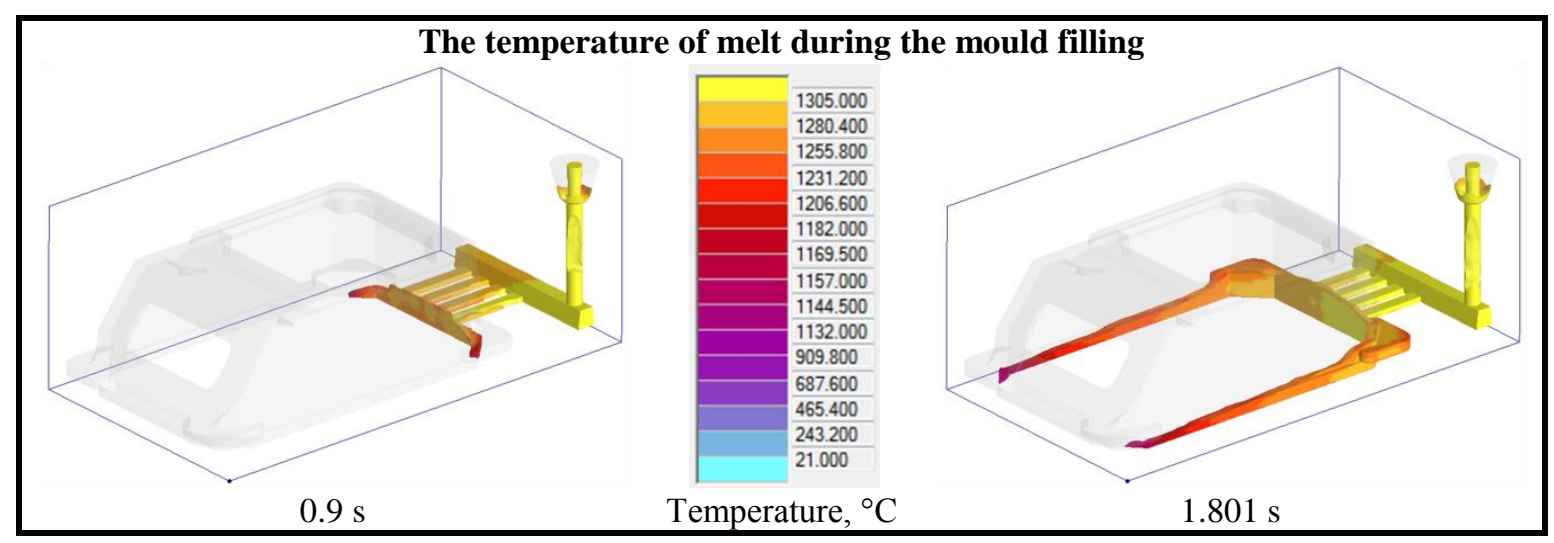




\begin{tabular}{l|lr|ll|ll} 
& ISRA (India) & $=\mathbf{1 . 3 4 4}$ & SIS (USA) & $=\mathbf{0 . 9 1 2}$ & ICV (Poland) & $=\mathbf{6 . 6 3 0}$ \\
Impact Factor: & ISI (Dubai, UAE) & $=\mathbf{0 . 8 2 9}$ & PUIH (Russia) & $=\mathbf{0 . 2 3 4}$ & PIF (India) & $=\mathbf{1 . 9 4 0}$ \\
& GIF (Australia) & $=\mathbf{0 . 5 6 4}$ & ESJI (KZ) & $=\mathbf{3 . 8 6 0}$ & IBI (India) & $\mathbf{4 . 2 6 0}$
\end{tabular}

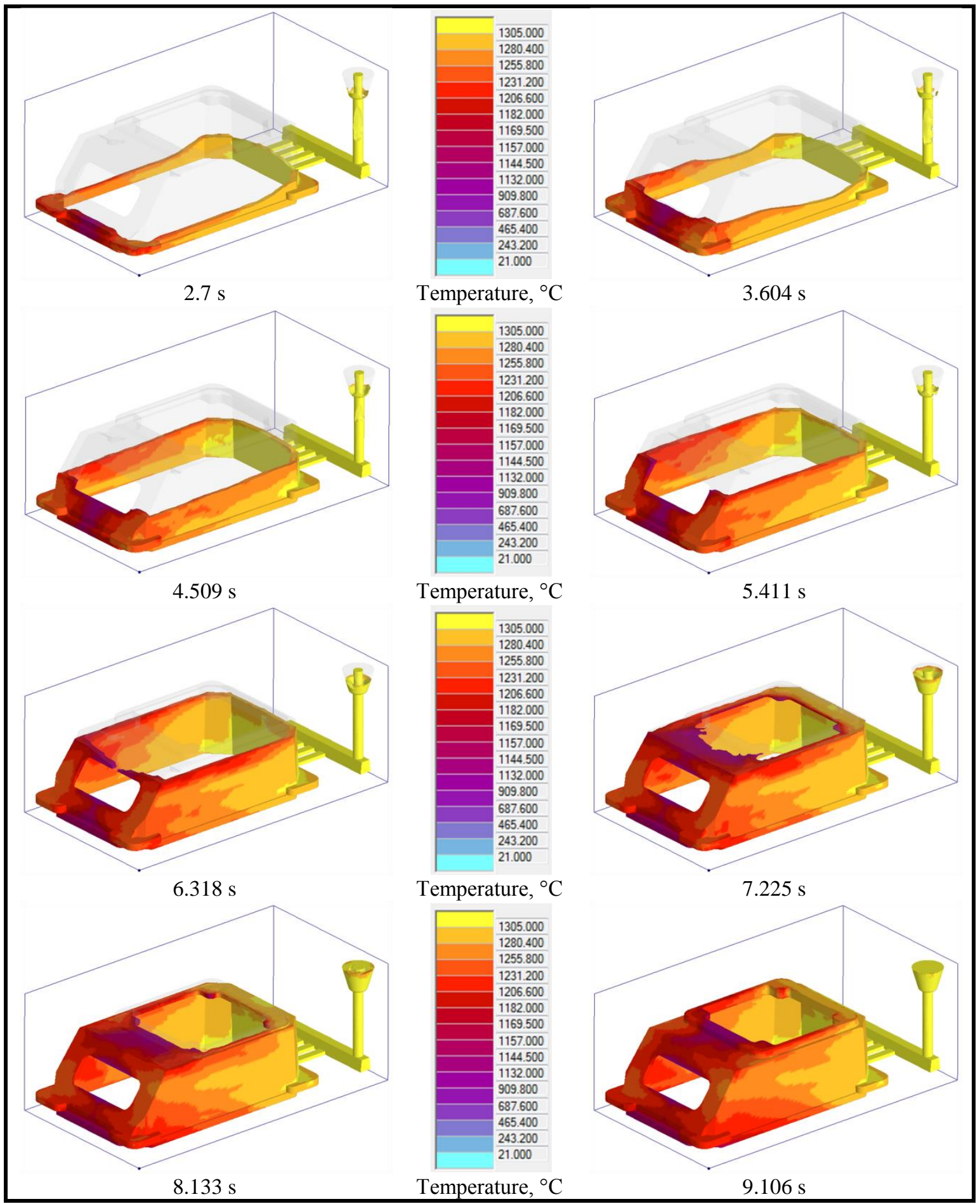




\begin{tabular}{l|lr|ll|ll} 
& ISRA (India) & $=\mathbf{1 . 3 4 4}$ & SIS (USA) & $=\mathbf{0 . 9 1 2}$ & ICV (Poland) & $\mathbf{= 6 . 6 3 0}$ \\
Impact Factor: & ISI (Dubai, UAE) $=\mathbf{0 . 8 2 9}$ & PUHL (Russia) & $=\mathbf{0 . 2 3 4}$ & PIF (India) & $=\mathbf{1 . 9 4 0}$ \\
& GIF (Australia) & $=\mathbf{0 . 5 6 4}$ & ESJI (KZ) & $=\mathbf{3 . 8 6 0}$ & IBI (India) & $\mathbf{4 . 2 6 0}$
\end{tabular}

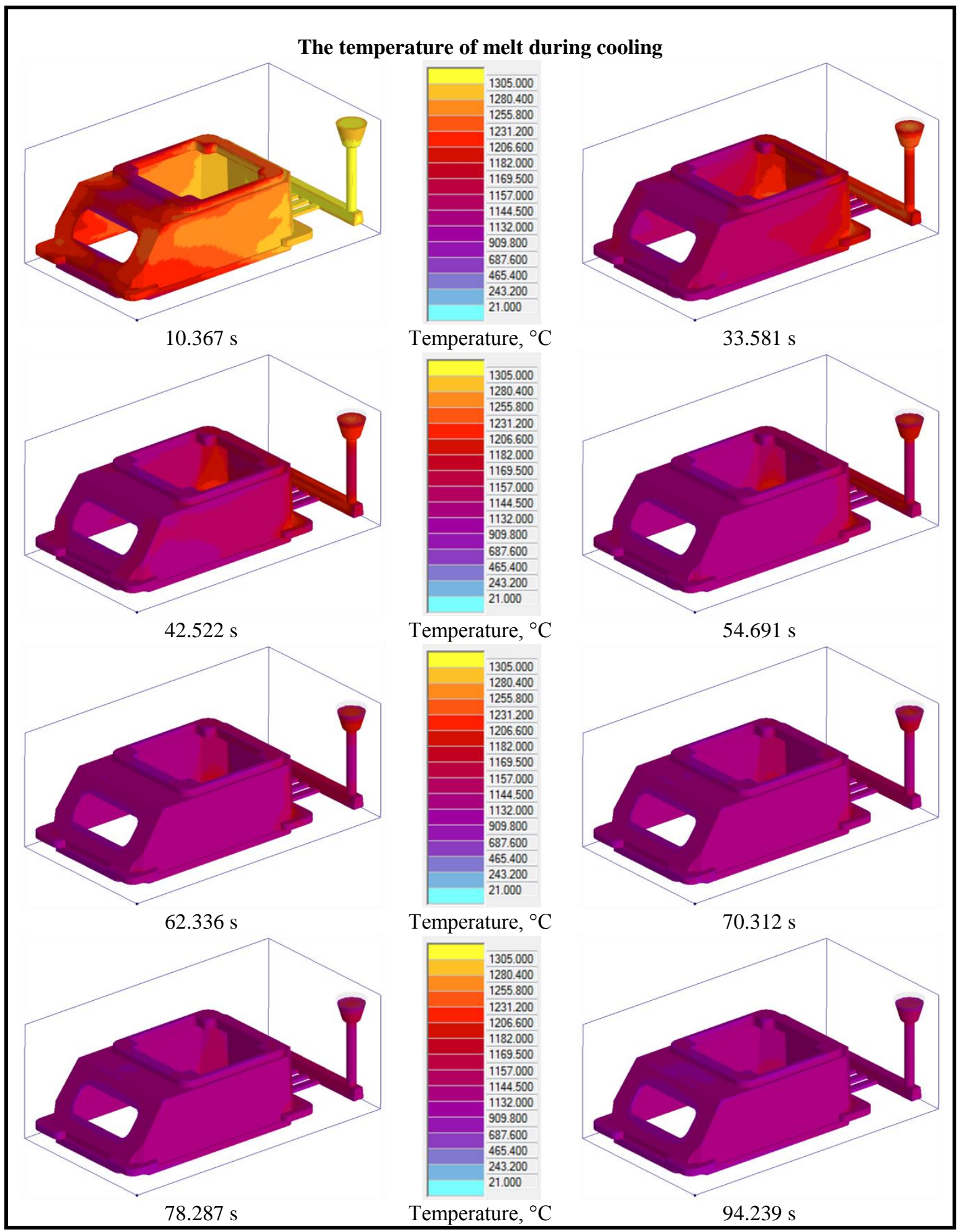




\begin{tabular}{|c|c|c|c|c|c|c|}
\hline Impact Factor: & $\begin{array}{l}\text { ISRA (India) } \\
\text { ISI (Dubai, UAF } \\
\text { GIF (Australia) } \\
\text { JIF }\end{array}$ & $\begin{array}{l}=1.344 \\
=0.829 \\
=0.564 \\
=1.500\end{array}$ & $\begin{array}{l}\text { SIS (USA) } \\
\text { PИНЦ (Russia) } \\
\text { ESJI (KZ) } \\
\text { SJIF (Morocco) }\end{array}$ & $\begin{array}{l}=0.912 \\
=0.234 \\
=3.860 \\
=\mathbf{2 . 0 3 1}\end{array}$ & $\begin{array}{l}\text { ICV (Poland) } \\
\text { PIF (India) } \\
\text { IBI (India) }\end{array}$ & $\begin{array}{l}=6.630 \\
=1.940 \\
=4.260\end{array}$ \\
\hline
\end{tabular}

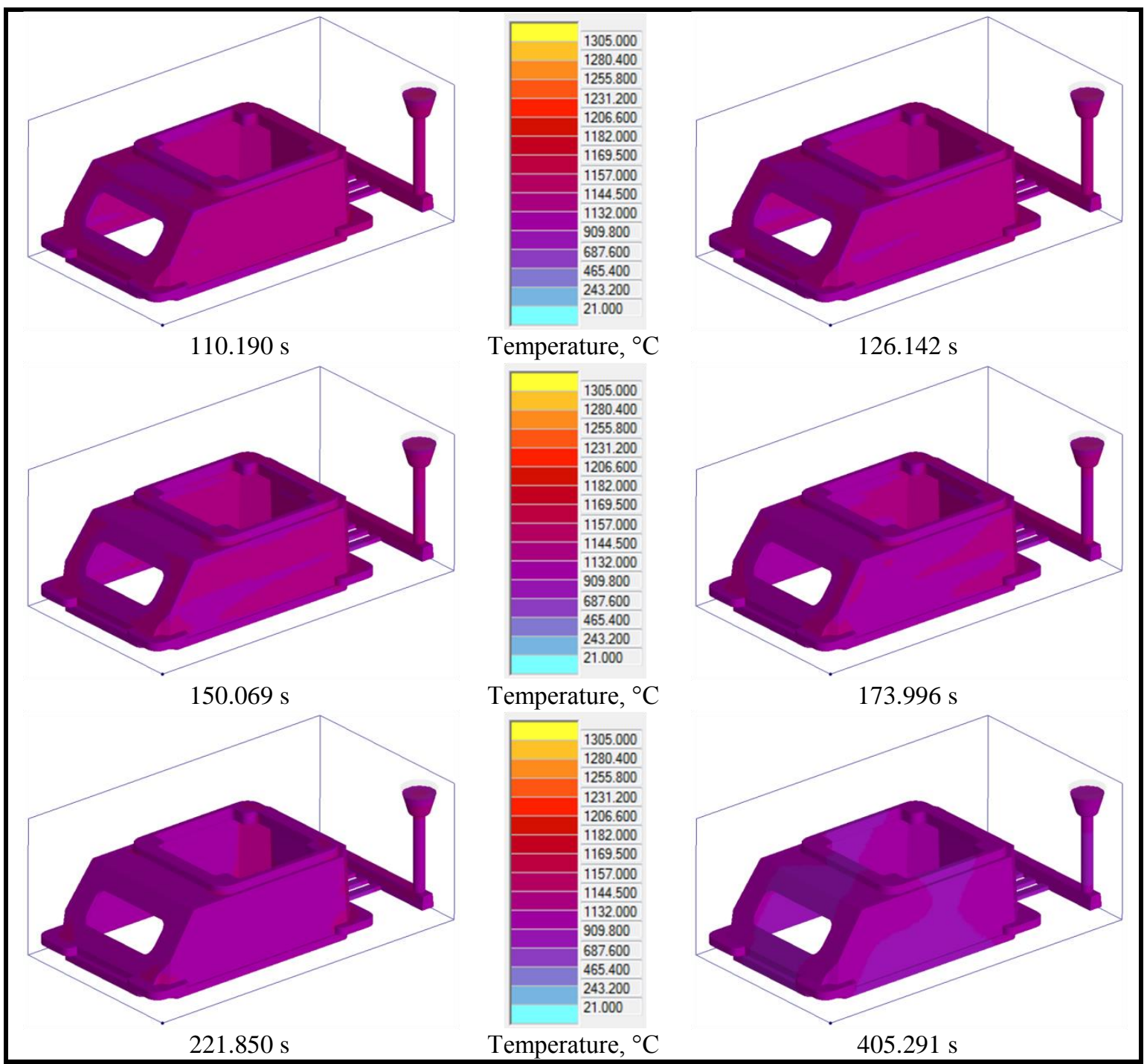

The analysis of the calculated fields of the temperature change of melt during the mould filling shows that during the first $3.604 \mathrm{~s}$ the temperature decreases in relation to the initial temperature by about $9 \%$. Melt, which is more distantly from the (gates) feeders, has the temperature close to the liquidus temperature. Cooled of the casting is slower than during filling, because there is only the heat transfer process. During filling, energy is expended on the motion of melt in the channels of the mould. The temperature during solidification of grey cast iron was about $450{ }^{\circ} \mathrm{C}$.

The calculated fields of ratio of the temperature change of melt during the mould filling and subsequent cooling to change the time of casting are presented in table 8 . 


\begin{tabular}{l|lr|ll|ll} 
& ISRA (India) & $=\mathbf{1 . 3 4 4}$ & SIS (USA) & $=\mathbf{0 . 9 1 2}$ & ICV (Poland) & $=\mathbf{6 . 6 3 0}$ \\
Impact Factor: & ISI (Dubai, UAE) $=\mathbf{0 . 8 2 9}$ & PUHI (Russia) & $=\mathbf{0 . 2 3 4}$ & PIF (India) & $=\mathbf{1 . 9 4 0}$ \\
& GIF (Australia) & $=\mathbf{0 . 5 6 4}$ & ESJI (KZ) & $=\mathbf{3 . 8 6 0}$ & IBI (India) & $\mathbf{4 . 2 6 0}$ \\
& JIF & $=\mathbf{1 . 5 0 0}$ & SJIF (Morocco) & $\mathbf{2 . 0 3 1}$ & & \\
\hline
\end{tabular}

Ratio of the temperature change of melt to change the time of casting.

Table 8

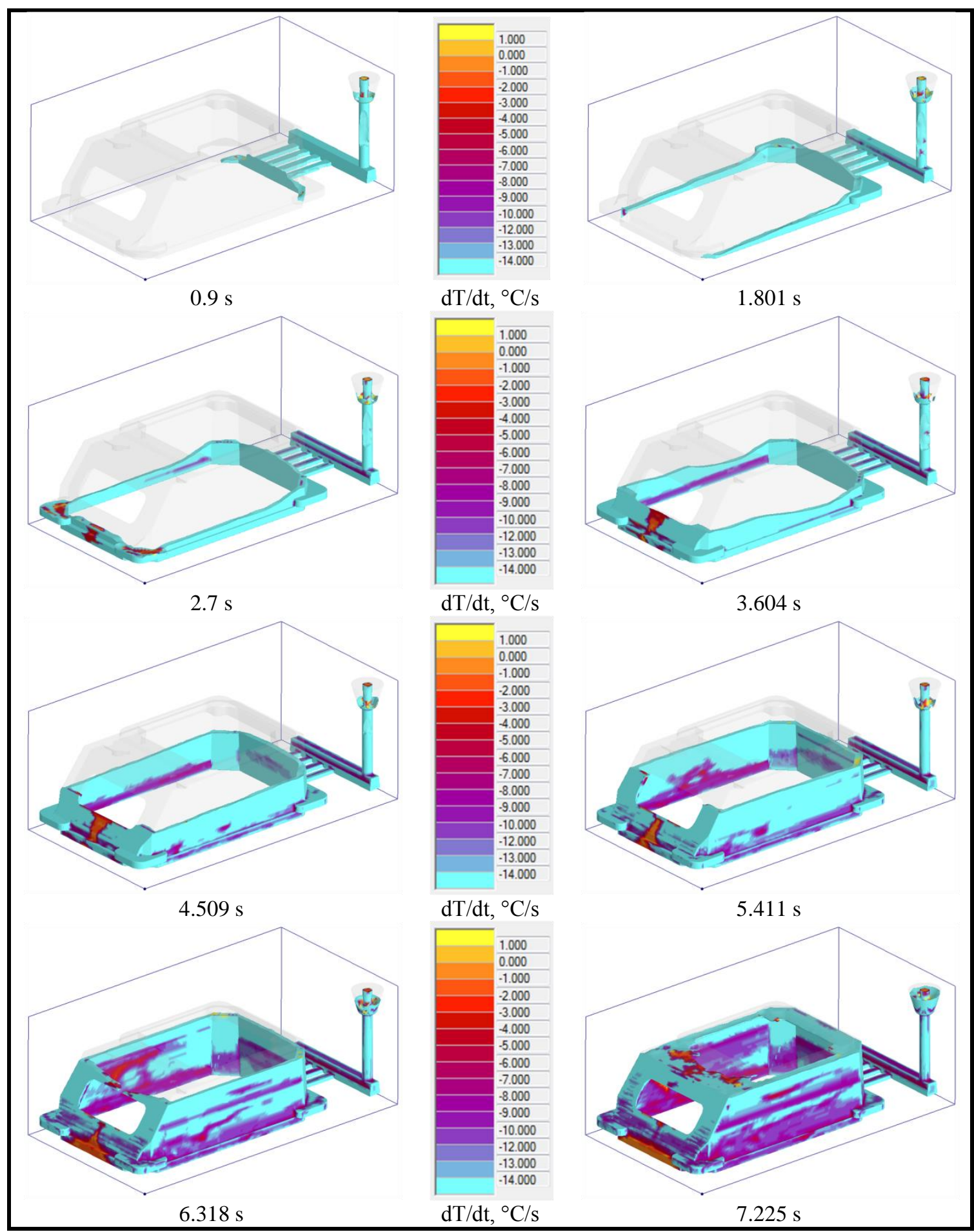




\begin{tabular}{l|lr|ll|ll} 
& ISRA (India) & $=\mathbf{1 . 3 4 4}$ & SIS (USA) & $=\mathbf{0 . 9 1 2}$ & ICV (Poland) & $=\mathbf{6 . 6 3 0}$ \\
Impact Factor: & ISI (Dubai, UAE) & $=\mathbf{0 . 8 2 9}$ & PUIH (Russia) & $=\mathbf{0 . 2 3 4}$ & PIF (India) & $=\mathbf{1 . 9 4 0}$ \\
& GIF (Australia) & $=\mathbf{0 . 5 6 4}$ & ESJI (KZ) & $=\mathbf{3 . 8 6 0}$ & IBI (India) & $\mathbf{4 . 2 6 0}$
\end{tabular}
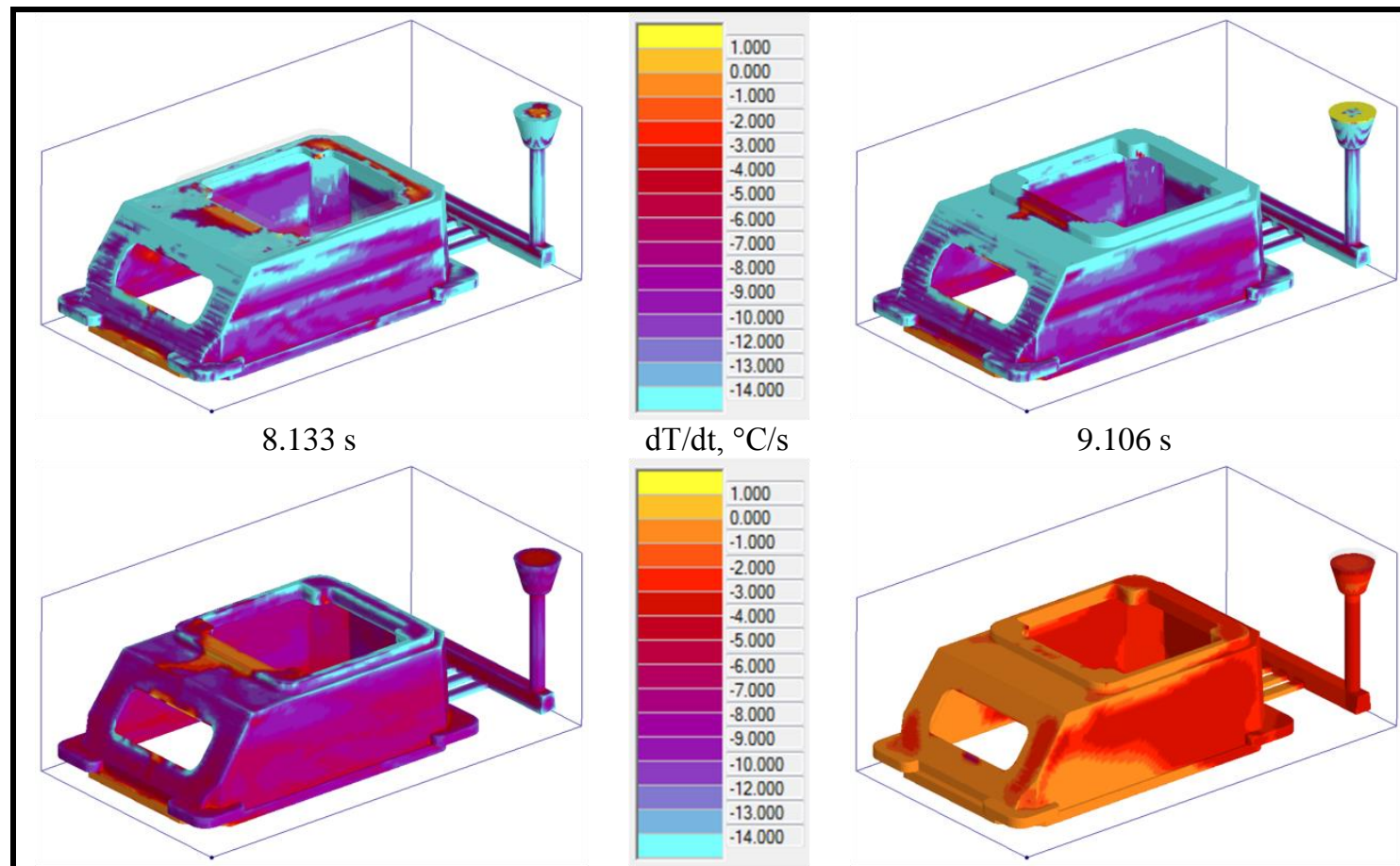

$\mathrm{dT} / \mathrm{dt},{ }^{\circ} \mathrm{C} / \mathrm{s}$
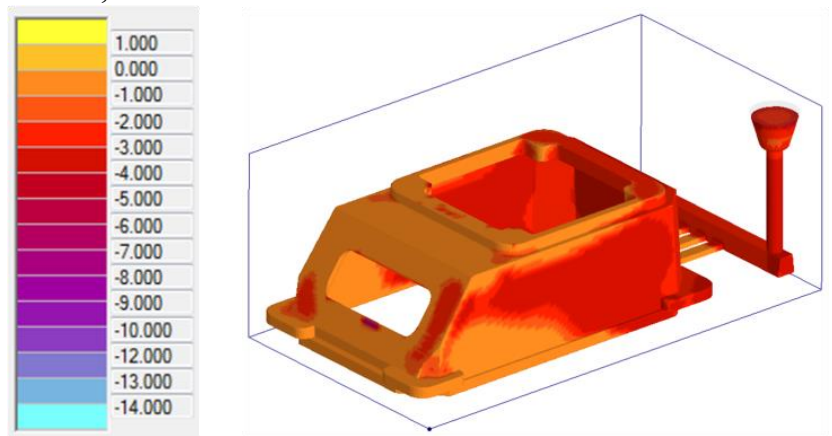

$10.367 \mathrm{~s}$

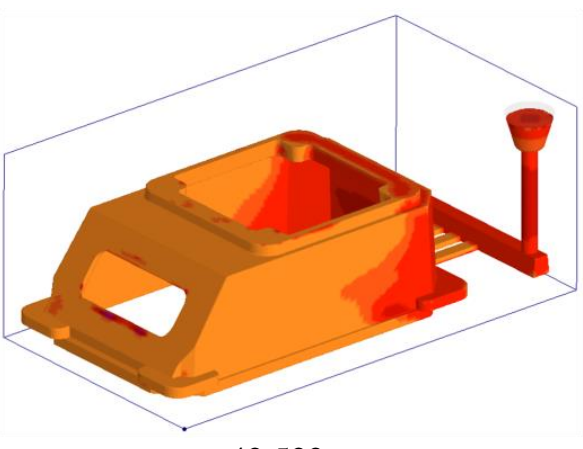

$\mathrm{dT} / \mathrm{dt},{ }^{\circ} \mathrm{C} / \mathrm{s}$

\section{$33.581 \mathrm{~s}$}
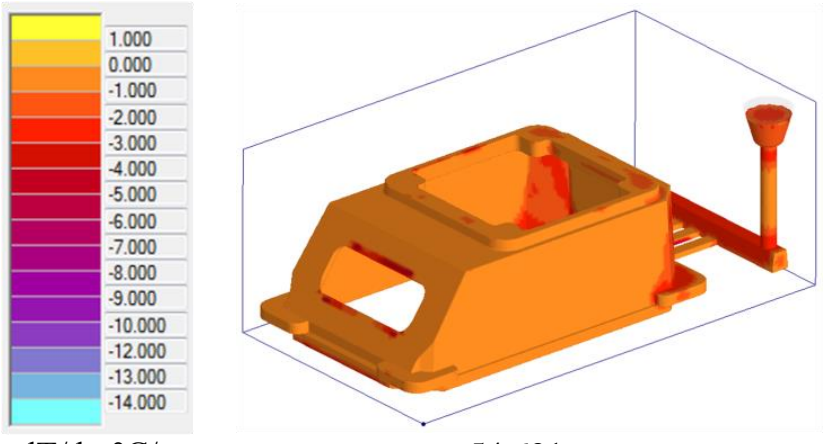

$\mathrm{dT} / \mathrm{dt},{ }^{\circ} \mathrm{C} / \mathrm{s}$

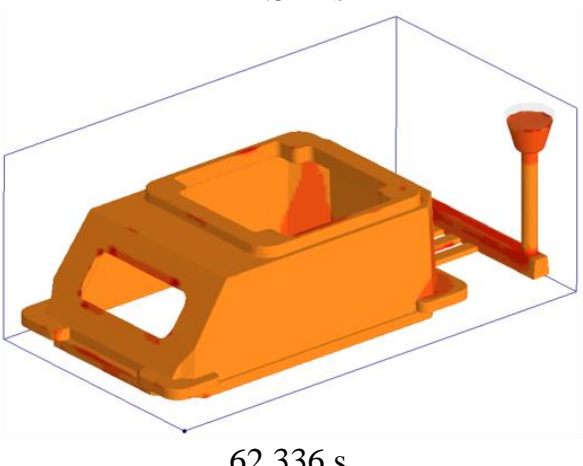

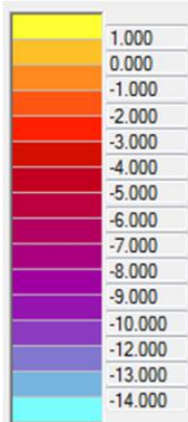

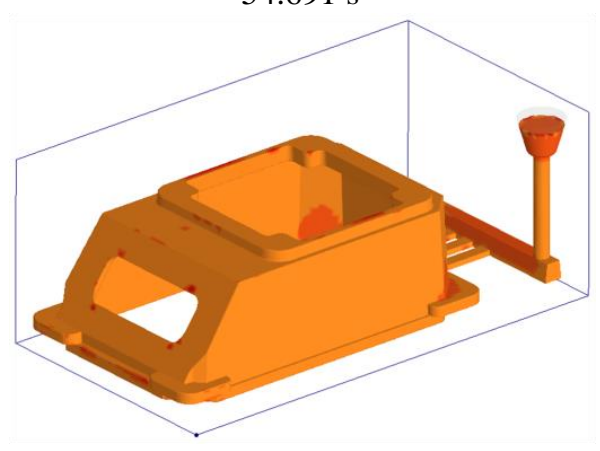

$\mathrm{dT} / \mathrm{dt},{ }^{\circ} \mathrm{C} / \mathrm{s}$

$70.312 \mathrm{~s}$ 


\begin{tabular}{|c|c|c|c|c|c|c|}
\hline Impact Factor: & $\begin{array}{l}\text { ISRA (India) } \\
\text { ISI (Dubai, UAE } \\
\text { GIF (Australia) } \\
\text { JIF }\end{array}$ & $\begin{array}{l}=1.344 \\
=0.829 \\
=0.564 \\
=1.500\end{array}$ & $\begin{array}{l}\text { SIS (USA) } \\
\text { PИНЦ (Russia) } \\
\text { ESJI (KZ) } \\
\text { SJIF (Morocco) }\end{array}$ & $\begin{array}{l}=0.912 \\
=0.234 \\
=3.860 \\
=\mathbf{2 . 0 3 1}\end{array}$ & $\begin{array}{l}\text { ICV (Poland) } \\
\text { PIF (India) } \\
\text { IBI (India) }\end{array}$ & $\begin{array}{l}=6.630 \\
=1.940 \\
=4.260\end{array}$ \\
\hline
\end{tabular}

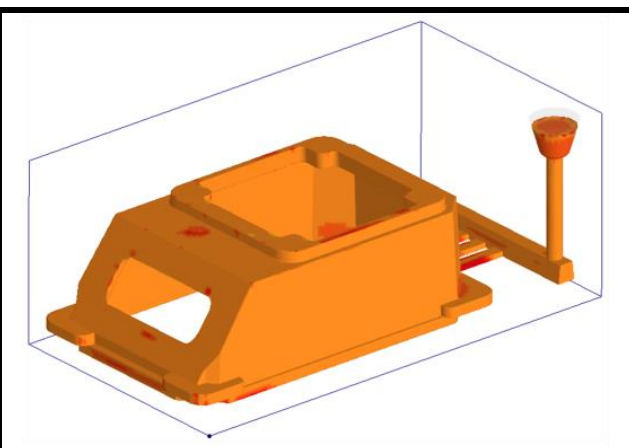

$78.287 \mathrm{~s}$

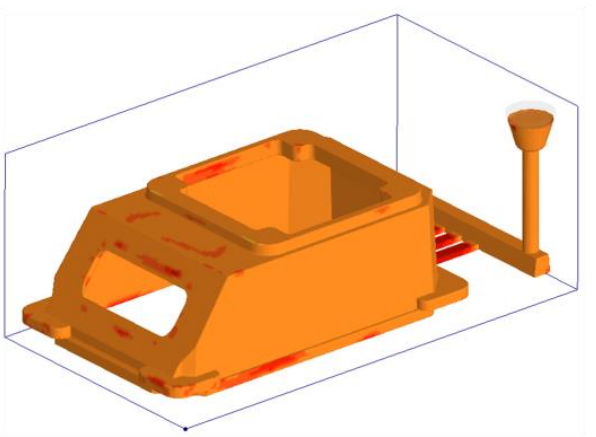

$110.190 \mathrm{~s}$

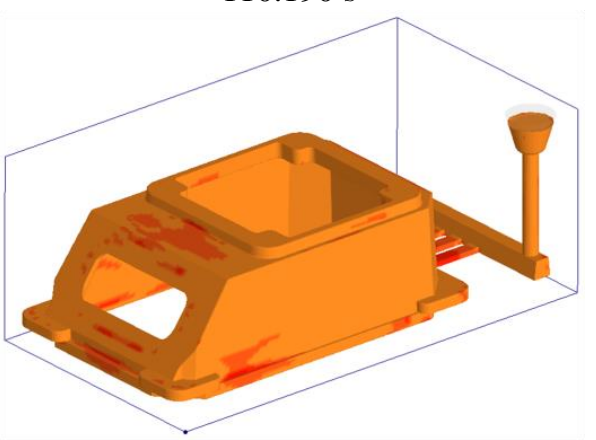

$150.069 \mathrm{~s}$

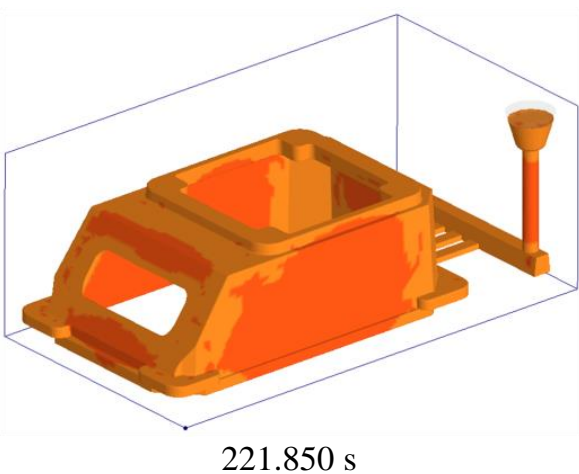

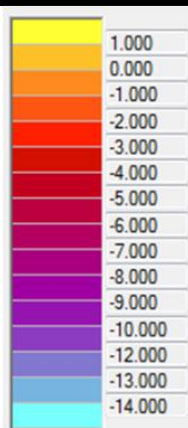

$\mathrm{dT} / \mathrm{dt},{ }^{\circ} \mathrm{C} / \mathrm{s}$

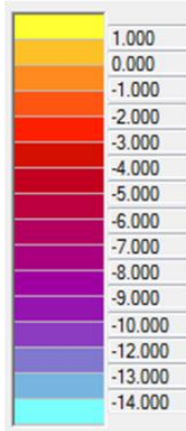

$\mathrm{dT} / \mathrm{dt},{ }^{\circ} \mathrm{C} / \mathrm{s}$

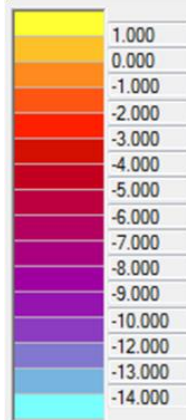

$\mathrm{dT} / \mathrm{dt},{ }^{\circ} \mathrm{C} / \mathrm{s}$

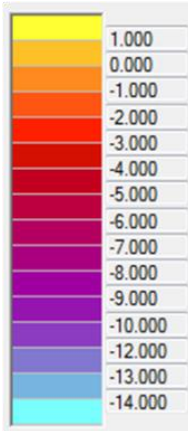

$\mathrm{dT} / \mathrm{dt},{ }^{\circ} \mathrm{C} / \mathrm{s}$
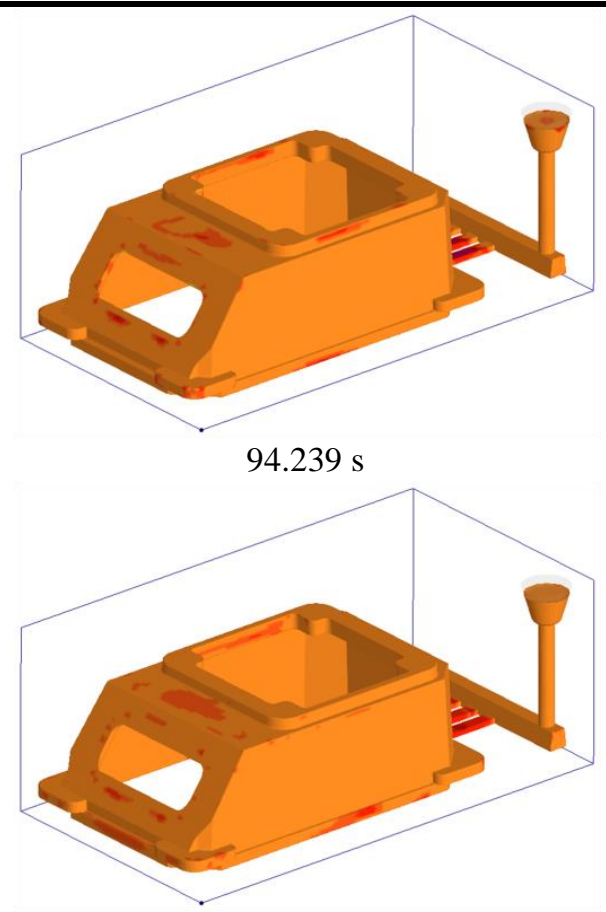

$126.142 \mathrm{~s}$

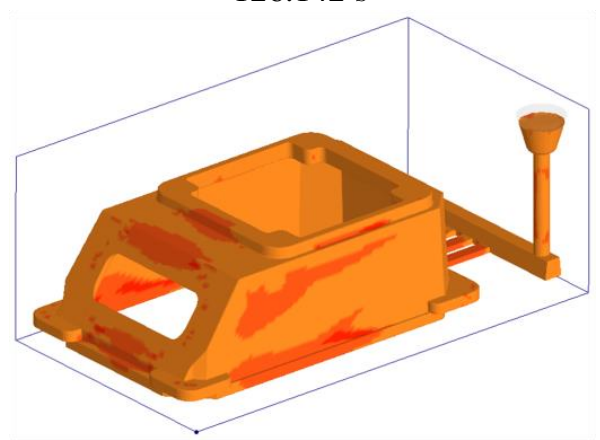

$173.996 \mathrm{~s}$

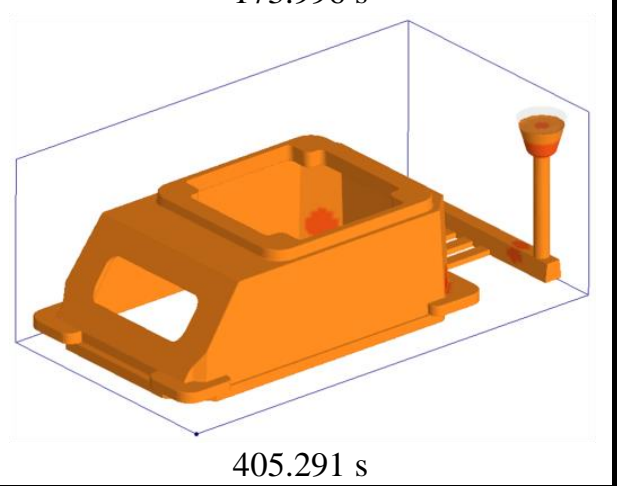

The first $3.604 \mathrm{~s}$ of the process of the mould filling are characterized by almost same cooling rate of melt. On the next $3.621 \mathrm{~s}$ of the mould filling it is observed the deceleration of cooling rate of melt. The process of melt solidification is occurred with uniform cooling rate. On the finite interval of the solidification time, energy of the inner layers of the casting material is transferred by the outer layers, therefore, there is the increase of cooling rate.

The calculated fields of the fraction of the liquid phase of the alloy during filling of the mould and subsequent cooling are presented in table 9 . 


\begin{tabular}{l|lr|ll|ll} 
& ISRA (India) & $=\mathbf{1 . 3 4 4}$ & SIS (USA) & $=\mathbf{0 . 9 1 2}$ & ICV (Poland) & $=\mathbf{6 . 6 3 0}$ \\
Impact Factor: & ISI (Dubai, UAE) $=\mathbf{0 . 8 2 9}$ & PUHI (Russia) & $=\mathbf{0 . 2 3 4}$ & PIF (India) & $=\mathbf{1 . 9 4 0}$ \\
& GIF (Australia) & $=\mathbf{0 . 5 6 4}$ & ESJI (KZ) & $=\mathbf{3 . 8 6 0}$ & IBI (India) & $\mathbf{4 . 2 6 0}$ \\
& JIF & $\mathbf{1 . 5 0 0}$ & SJIF (Morocco) & $\mathbf{2 . 0 3 1}$ & & \\
\hline
\end{tabular}

The fraction of the liquid phase of the alloy (filling and cooling).

Table 9

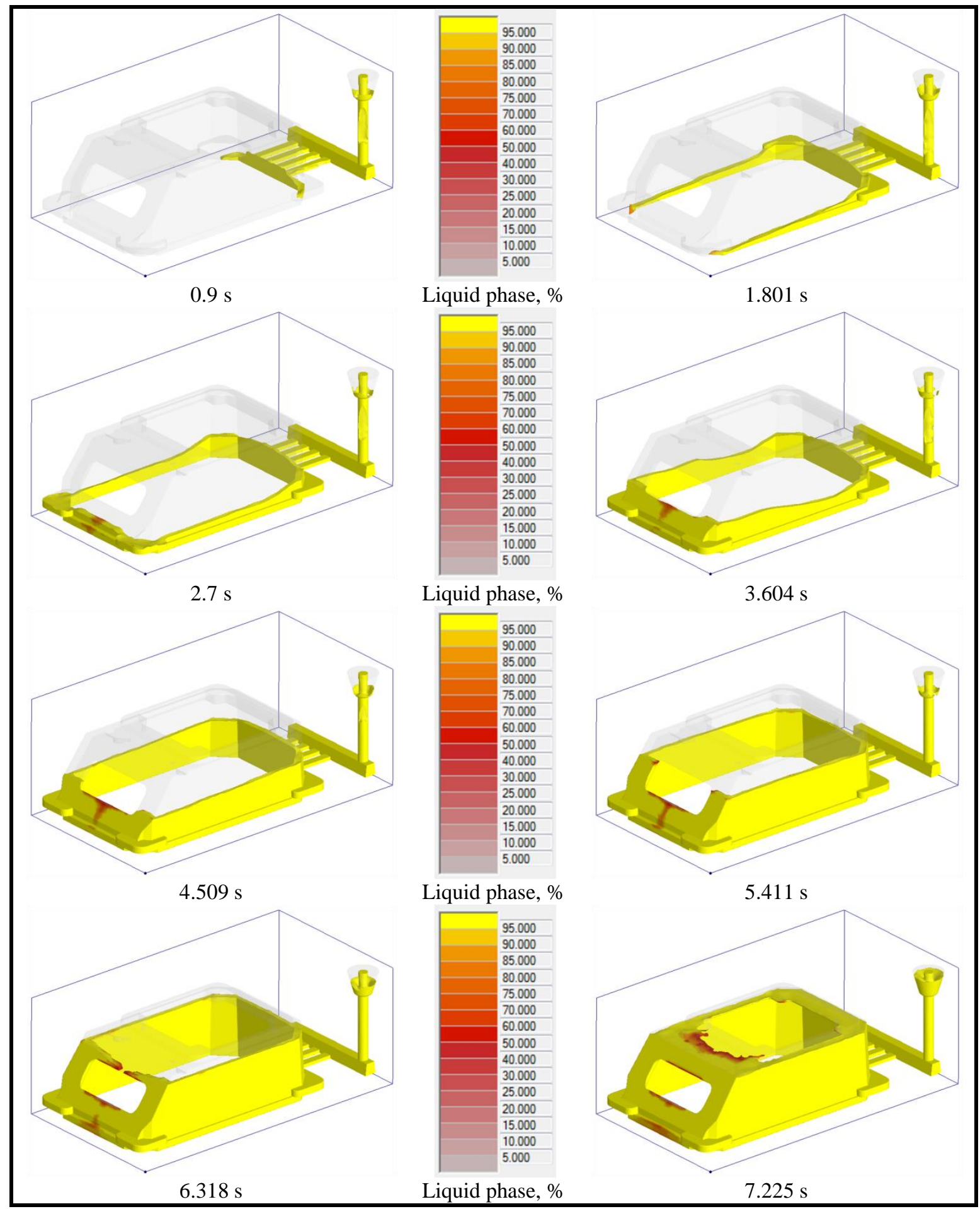




\begin{tabular}{|c|c|c|c|c|c|c|}
\hline Impact Factor: & $\begin{array}{l}\text { ISRA (India) } \\
\text { ISI (Dubai, UAE } \\
\text { GIF (Australia) } \\
\text { JIF }\end{array}$ & $\begin{array}{l}=1.344 \\
=0.829 \\
=0.564 \\
=1.500\end{array}$ & $\begin{array}{l}\text { SIS (USA) } \\
\text { PИНЦ (Russia) } \\
\text { ESJI (KZ) } \\
\text { SJIF (Morocco) }\end{array}$ & $\begin{array}{l}=0.912 \\
=0.234 \\
=3.860 \\
=\mathbf{2 . 0 3 1}\end{array}$ & $\begin{array}{l}\text { ICV (Poland) } \\
\text { PIF (India) } \\
\text { IBI (India) }\end{array}$ & $\begin{array}{l}=6.630 \\
=1.940 \\
=4.260\end{array}$ \\
\hline
\end{tabular}

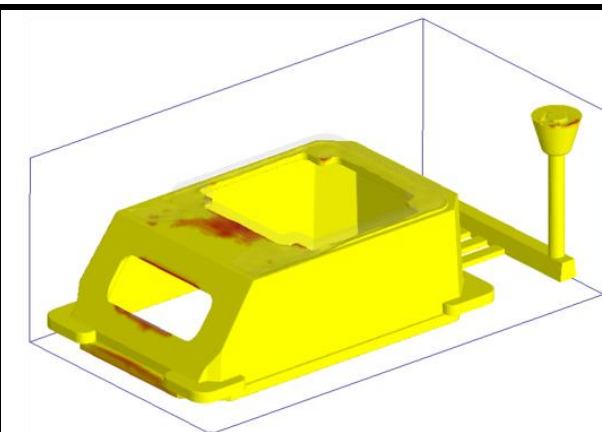

$8.133 \mathrm{~s}$

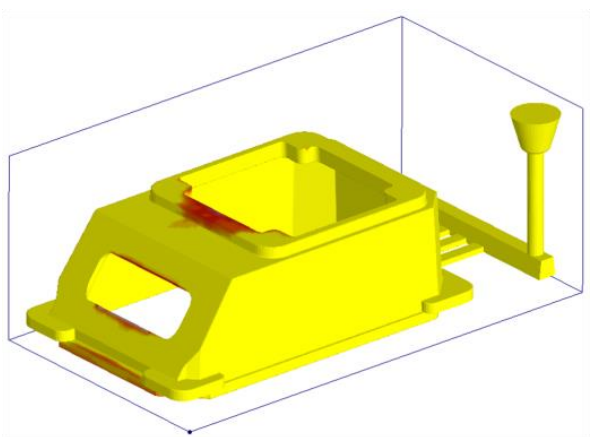

$10.367 \mathrm{~s}$

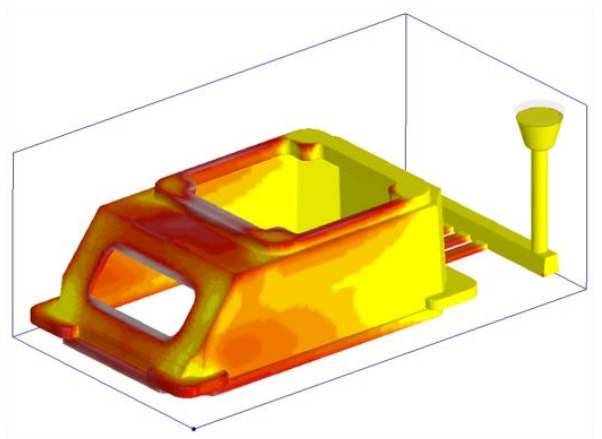

$42.522 \mathrm{~s}$

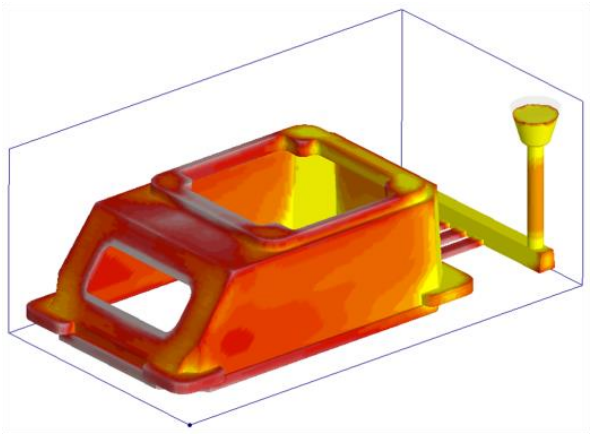

$62.336 \mathrm{~s}$

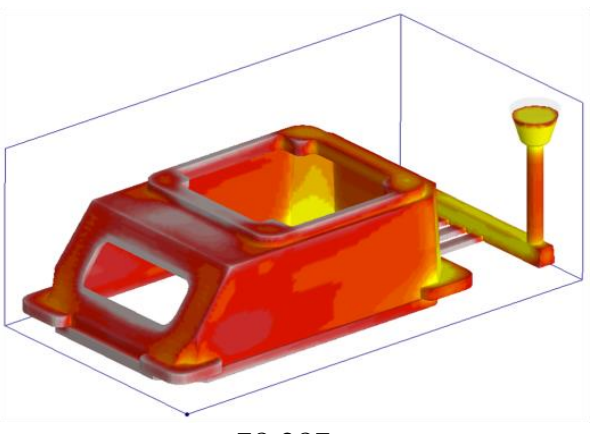

78.287

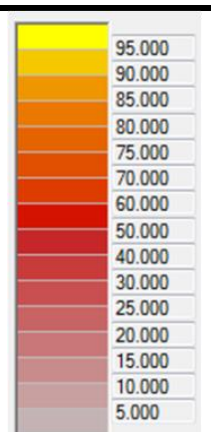

Liquid phase, $\%$

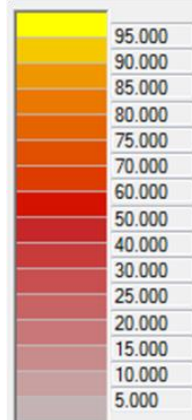

Liquid phase, $\%$

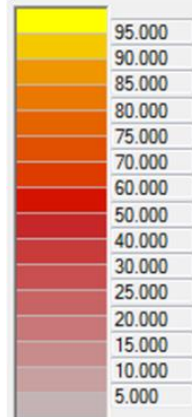

Liquid phase, $\%$

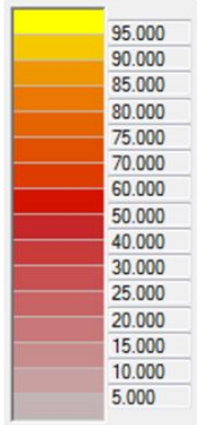

Liquid phase, $\%$

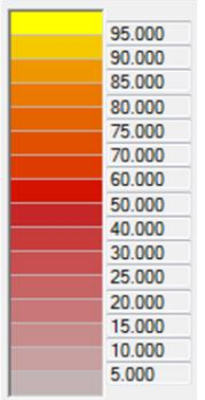

Liquid phase, $\%$

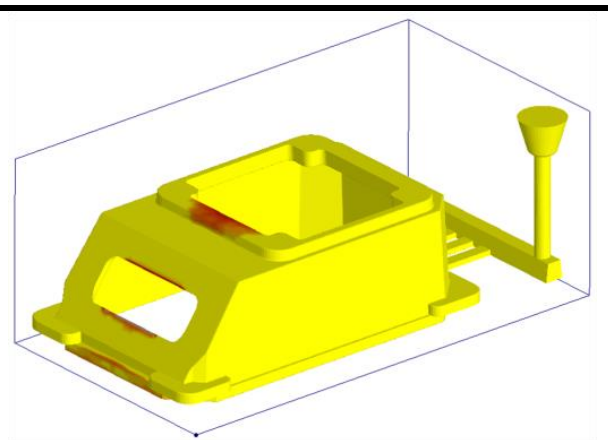

$9.106 \mathrm{~s}$

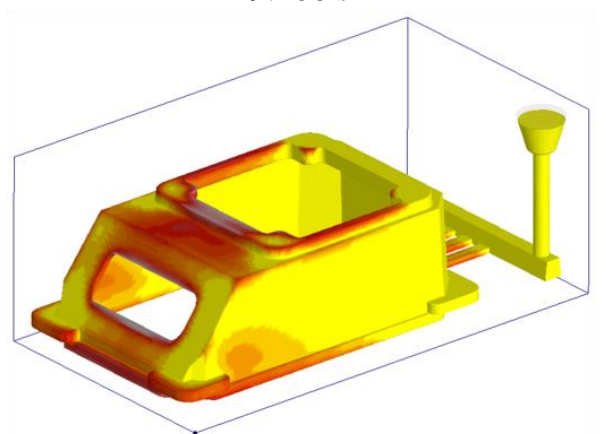

$33.581 \mathrm{~s}$

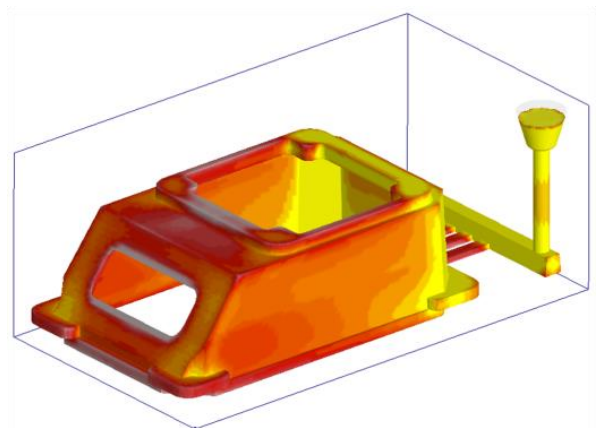

$54.691 \mathrm{~s}$

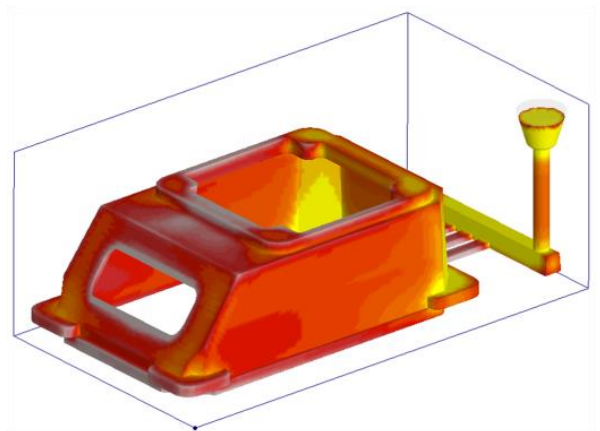

$70.312 \mathrm{~s}$

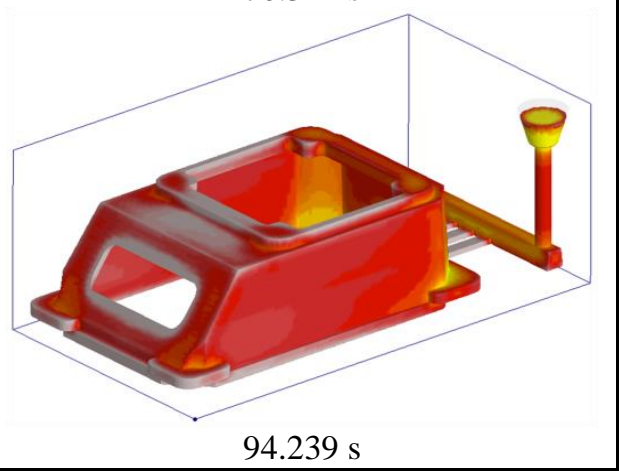

ISPC Technology and Education, 


\begin{tabular}{|c|c|c|c|c|c|c|}
\hline Impact Factor: & $\begin{array}{l}\text { ISRA (India) } \\
\text { ISI (Dubai, UAE } \\
\text { GIF (Australia) } \\
\text { JIF }\end{array}$ & $\begin{array}{l}=1.344 \\
=0.829 \\
=0.564 \\
=1.500\end{array}$ & $\begin{array}{l}\text { SIS (USA) } \\
\text { PИНЦ (Russia) } \\
\text { ESJI (KZ) } \\
\text { SJIF (Morocco) }\end{array}$ & $\begin{array}{l}=0.912 \\
=0.234 \\
=3.860 \\
=\mathbf{2 . 0 3 1}\end{array}$ & $\begin{array}{l}\text { ICV (Poland) } \\
\text { PIF (India) } \\
\text { IBI (India) }\end{array}$ & $\begin{array}{l}=6.630 \\
=1.940 \\
=4.260\end{array}$ \\
\hline
\end{tabular}

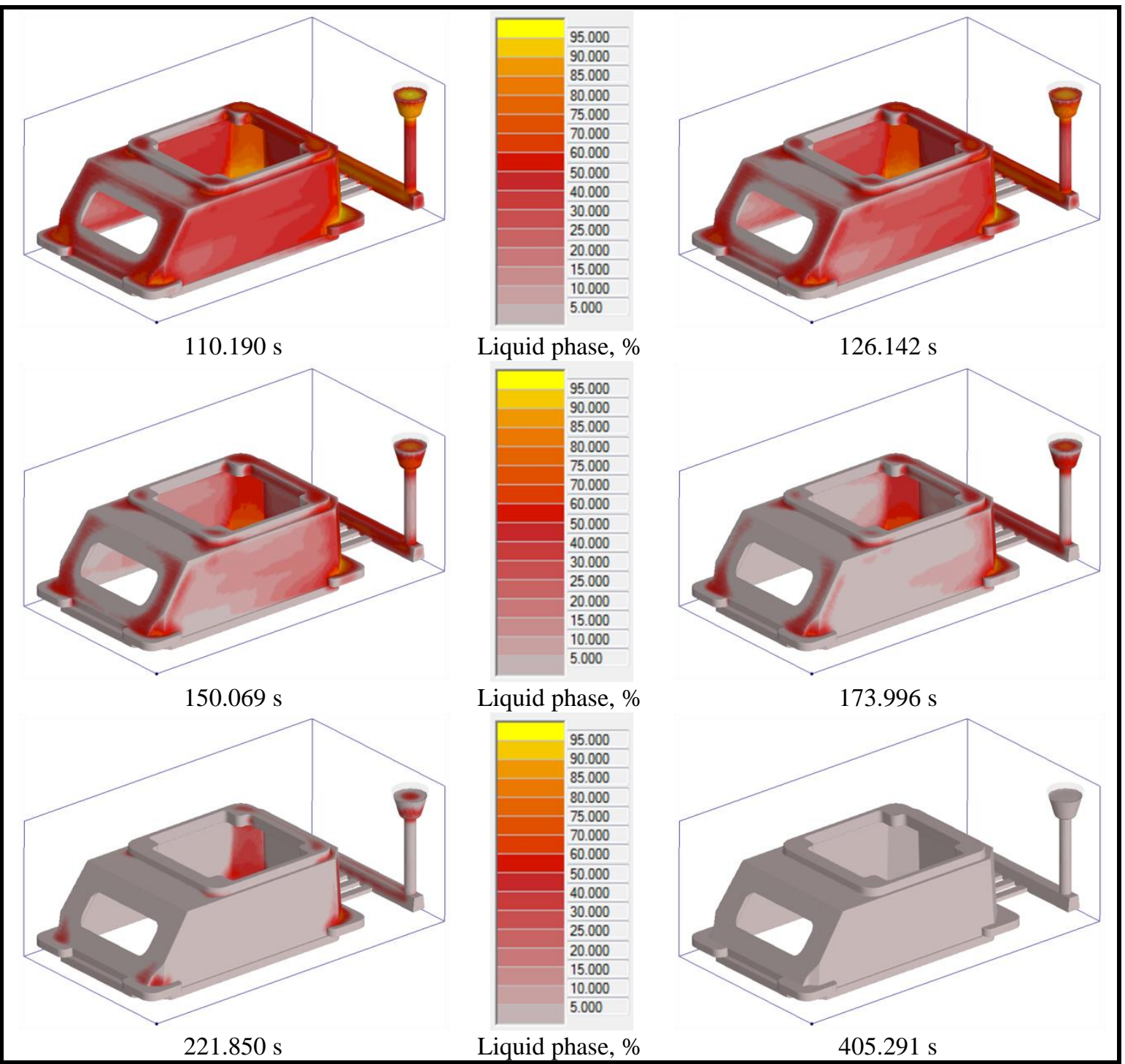

In accordance with the calculated fields, it is possible to observe that to complete filling of the channels of the mould, the alloy is in the liquid state. The exceptions are the some volumes of the alloy (approximately $5 \%$ ) at the bottom part and the side window of the casting. The volume of the alloy poured into the mould is solidified unevenly. The crystallization process is slower on the angular bends of the casting. This may affect on its quality, because in these places there are residual deformations of the material. The forecast of the formation of residual deformations is correct and for the bottom of the casting.

The calculated fields of pressure in melt during filling of the mould are presented in table 10.

During the mould filling, pressure in melt is changed in the range from 0.02 to 0.05 bar. The side surfaces of the casting are exposed by variable pressure. 


\begin{tabular}{|c|c|c|c|c|c|c|}
\hline Impact Factor: & $\begin{array}{l}\text { ISRA (India) } \\
\text { ISI (Dubai, UAF } \\
\text { GIF (Australia) } \\
\text { JIF }\end{array}$ & $\begin{array}{r}=1.344 \\
=0.829 \\
=0.564 \\
=1.500\end{array}$ & $\begin{array}{l}\text { SIS (USA) } \\
\text { PИНЦ (Russia) } \\
\text { ESJI (KZ) } \\
\text { SJIF (Morocco) }\end{array}$ & $\begin{array}{l}=0.912 \\
=0.234 \\
=3.860 \\
=\mathbf{2 . 0 3 1}\end{array}$ & $\begin{array}{l}\text { ICV (Poland) } \\
\text { PIF (India) } \\
\text { IBI (India) }\end{array}$ & $\begin{array}{l}=6.630 \\
=1.940 \\
=4.260\end{array}$ \\
\hline
\end{tabular}

Pressure in melt during filling of the mould.

Table 10

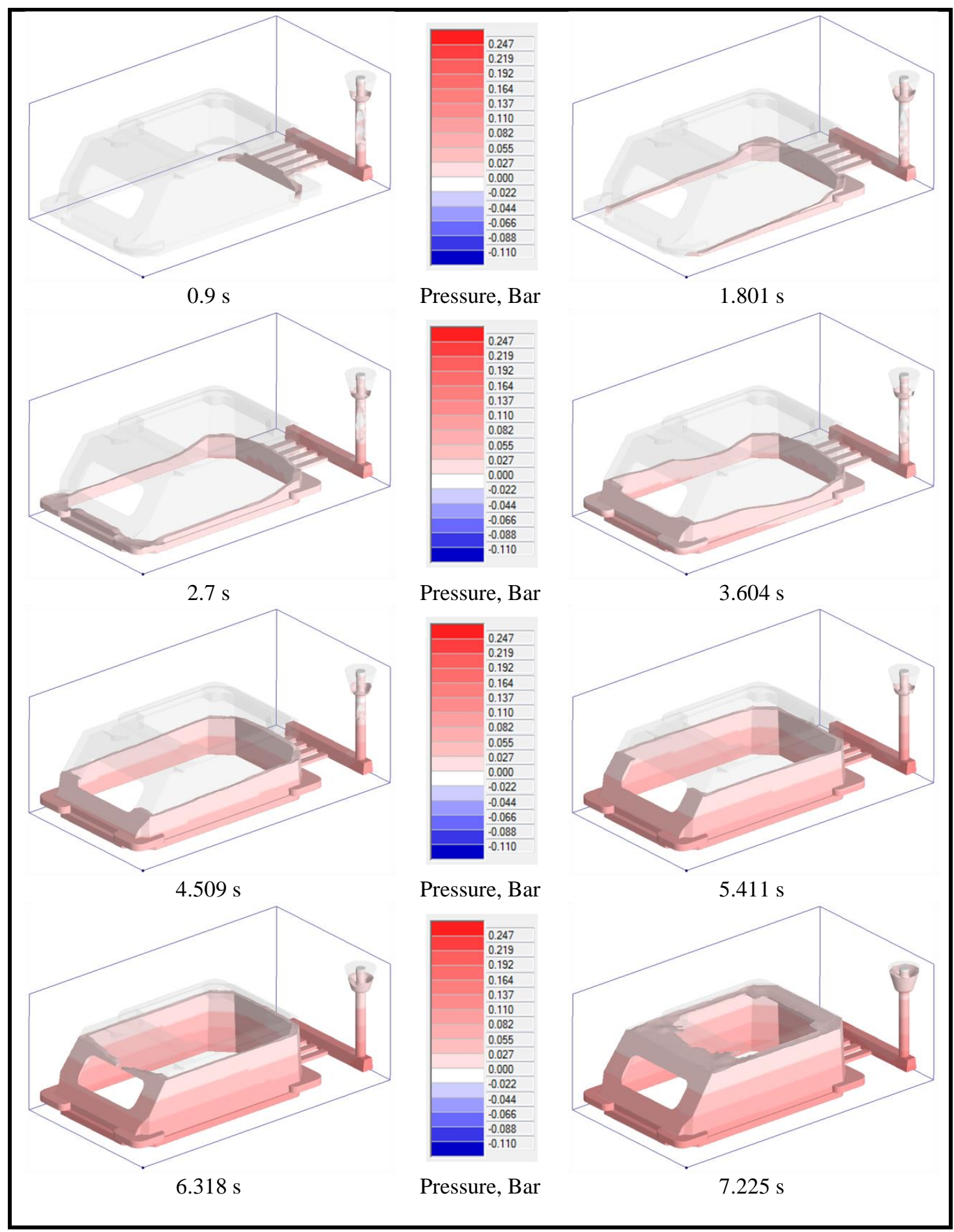




\begin{tabular}{|c|c|c|c|c|c|c|}
\hline Impact Factor: & $\begin{array}{l}\text { ISRA (India) } \\
\text { ISI (Dubai, UAE } \\
\text { GIF (Australia) } \\
\text { JIF }\end{array}$ & $\begin{array}{l}=1.344 \\
=0.829 \\
=0.564 \\
=1.500\end{array}$ & $\begin{array}{l}\text { SIS (USA) } \\
\text { PИНЦ (Russia) } \\
\text { ESJI (KZ) } \\
\text { SJIF (Morocco) }\end{array}$ & $\begin{array}{l}=0.912 \\
=0.234 \\
=3.860 \\
=\mathbf{2 . 0 3 1}\end{array}$ & $\begin{array}{l}\text { ICV (Poland) } \\
\text { PIF (India) } \\
\text { IBI (India) }\end{array}$ & $\begin{array}{l}=6.630 \\
=1.940 \\
=4.260\end{array}$ \\
\hline
\end{tabular}

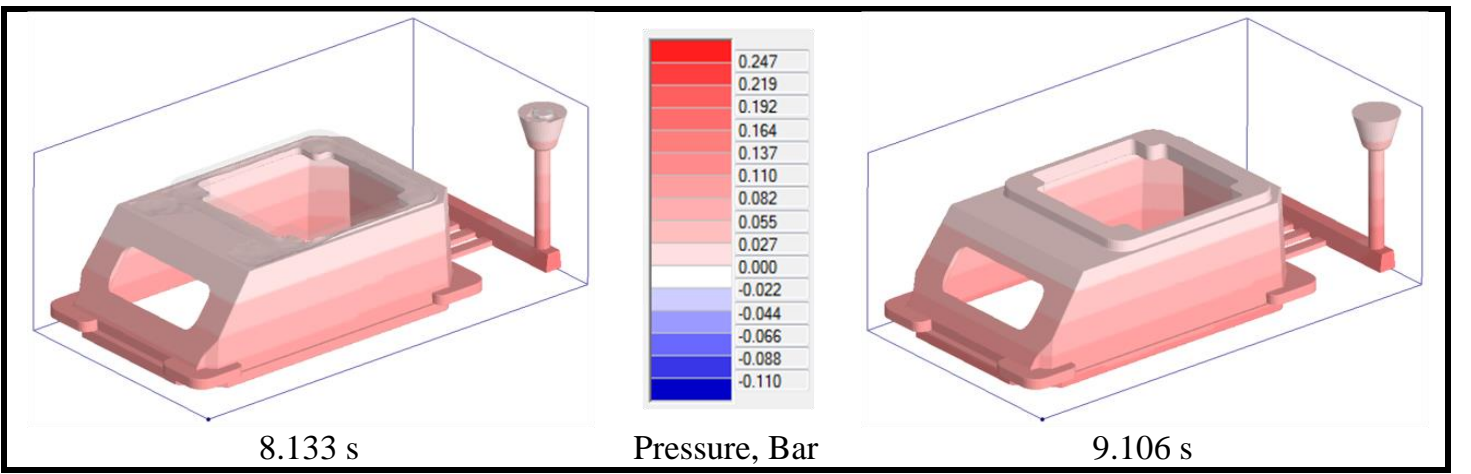

The least pressure is concentrated at the bottom part of the casting, the highest pressure is concentrated on the top part of the casting. The calculated fields of the velocities of melt during filling of the mould are presented in table 11.
The velocity of melt flow doesn't change throughout of the mould filling because casting occurs without the application of external pressure, but only under the action of the gravitational forces. It speaks about a uniform distribution of melt throughout the volume of the mould.

The velocities of melt during filling of the mould.

Table 11

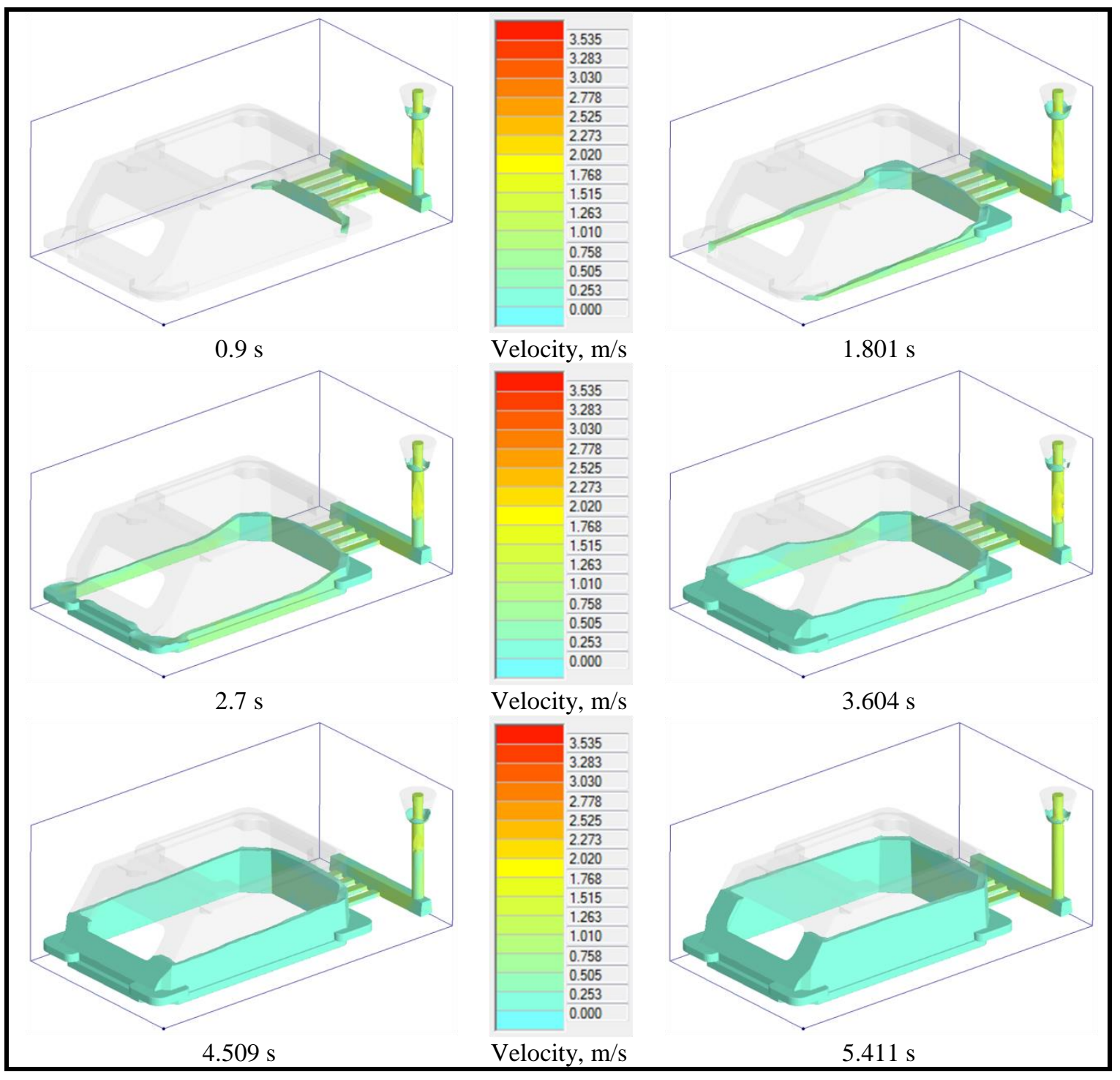

ISPC Technology and Education,

Philadelphia, USA 


\begin{tabular}{|c|c|c|c|c|c|c|}
\hline Impact Factor: & $\begin{array}{l}\text { ISRA (India) } \\
\text { ISI (Dubai, UAF } \\
\text { GIF (Australia) } \\
\text { JIF }\end{array}$ & $\begin{array}{l}=1.344 \\
=0.829 \\
=0.564 \\
=1.500\end{array}$ & $\begin{array}{l}\text { SIS (USA) } \\
\text { PИНЦ (Russia) } \\
\text { ESJI (KZ) } \\
\text { SJIF (Morocco) }\end{array}$ & $\begin{array}{l}=0.912 \\
=0.234 \\
=3.860 \\
=\mathbf{2 . 0 3 1}\end{array}$ & $\begin{array}{l}\text { ICV (Poland) } \\
\text { PIF (India) } \\
\text { IBI (India) }\end{array}$ & $\begin{array}{l}=6.630 \\
=1.940 \\
=4.260\end{array}$ \\
\hline
\end{tabular}

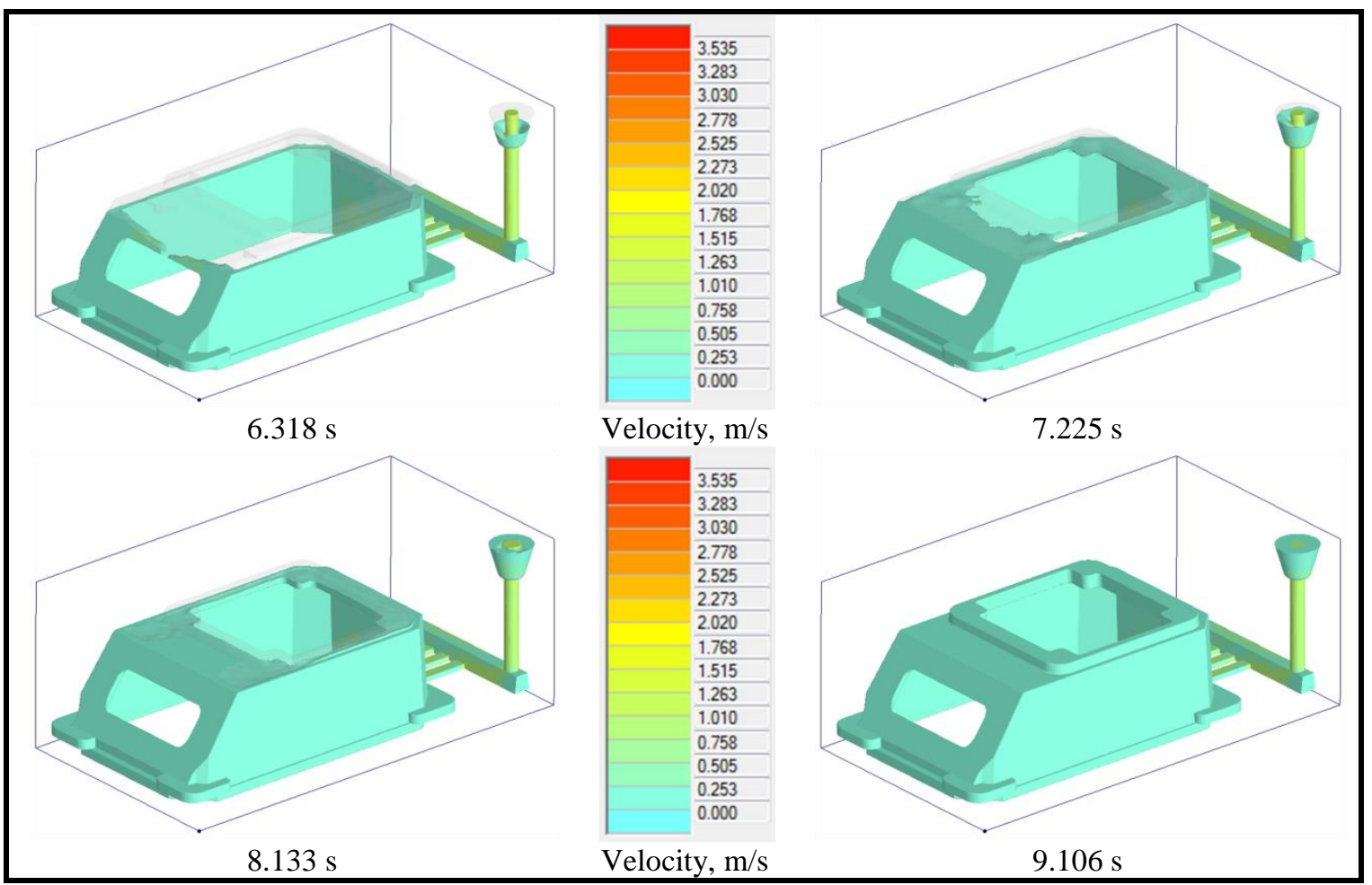

The calculated fields of the contact time of melt with the walls of the mould are presented in table 12 .

The contact time of melt with the walls of the mould is less the filling time. This is due to the fact that liquid alloy flows from layer to layer and has the minimal contact with the walls of the channels of the sand mould.

The calculated field of work effectiveness of the gating-feeding system is presented in table 13 .

The contact time of melt with the walls of the sand mould.

Table 12

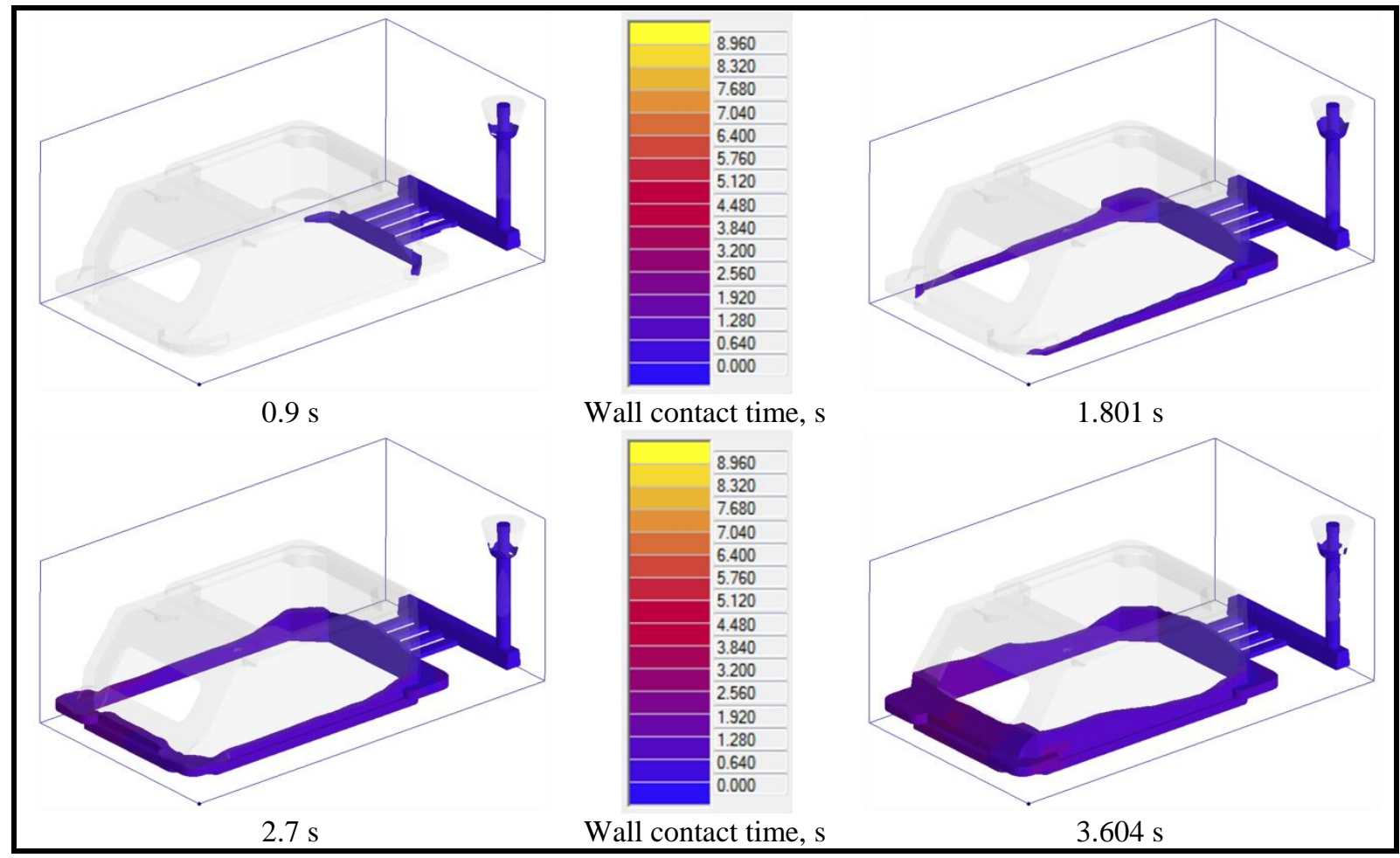

ISPC Technology and Education,

Philadelphia, USA 


\begin{tabular}{|c|c|c|c|c|c|c|}
\hline Impact Factor: & $\begin{array}{l}\text { ISRA (India) } \\
\text { ISI (Dubai, UAE } \\
\text { GIF (Australia) } \\
\text { JIF }\end{array}$ & $\begin{array}{l}=1.344 \\
=0.829 \\
=0.564 \\
=1.500\end{array}$ & $\begin{array}{l}\text { SIS (USA) } \\
\text { PИНЦ (Russia) } \\
\text { ESJI (KZ) } \\
\text { SJIF (Morocco) }\end{array}$ & $\begin{array}{l}=0.912 \\
=\mathbf{0 . 2 3 4} \\
=\mathbf{3 . 8 6 0} \\
=\mathbf{2 . 0 3 1}\end{array}$ & $\begin{array}{l}\text { ICV (Poland) } \\
\text { PIF (India) } \\
\text { IBI (India) }\end{array}$ & $\begin{array}{l}=6.630 \\
=1.940 \\
=4.260\end{array}$ \\
\hline
\end{tabular}

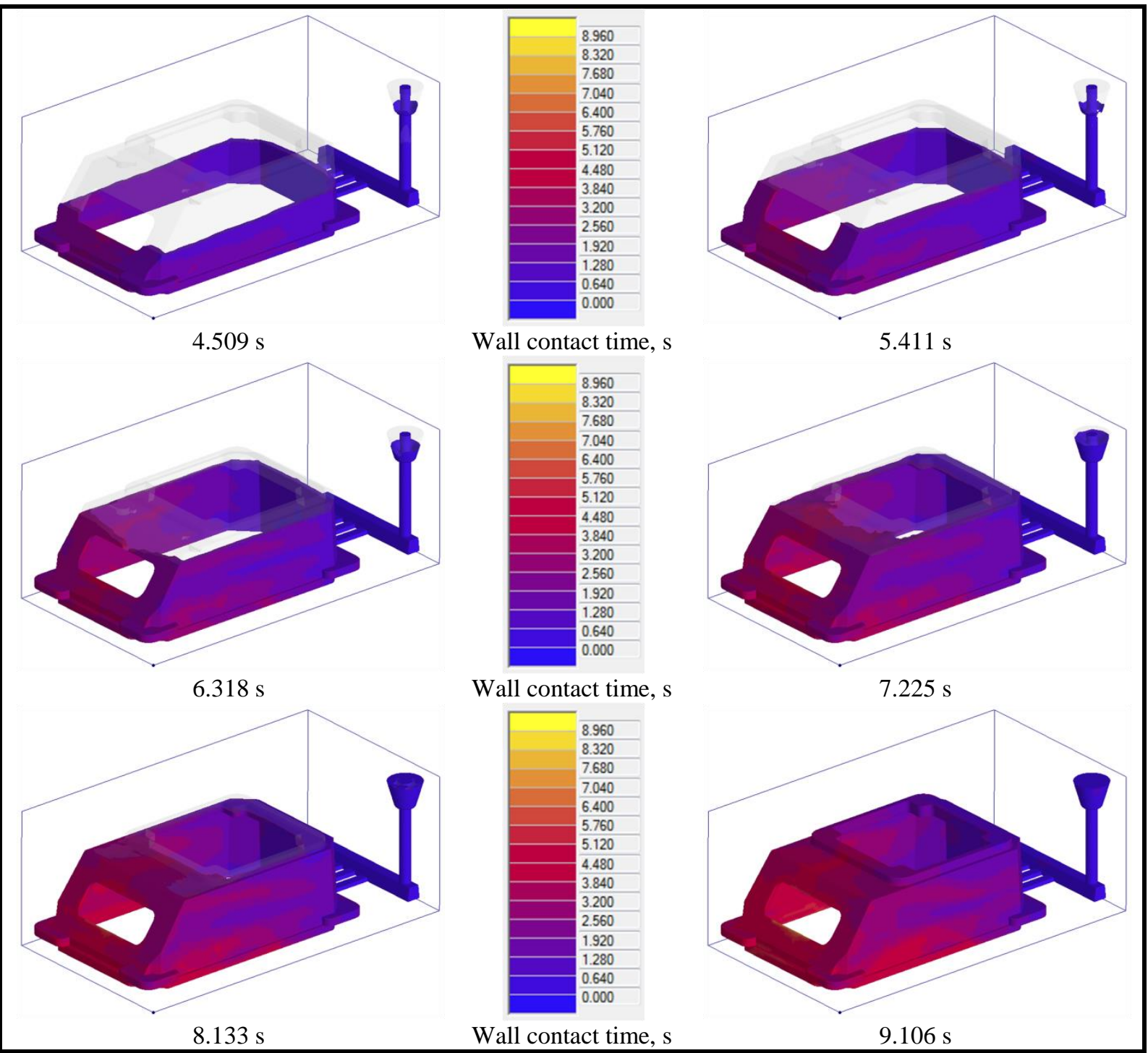

The assessment of effectiveness of the gating-feeding system.

Table 13

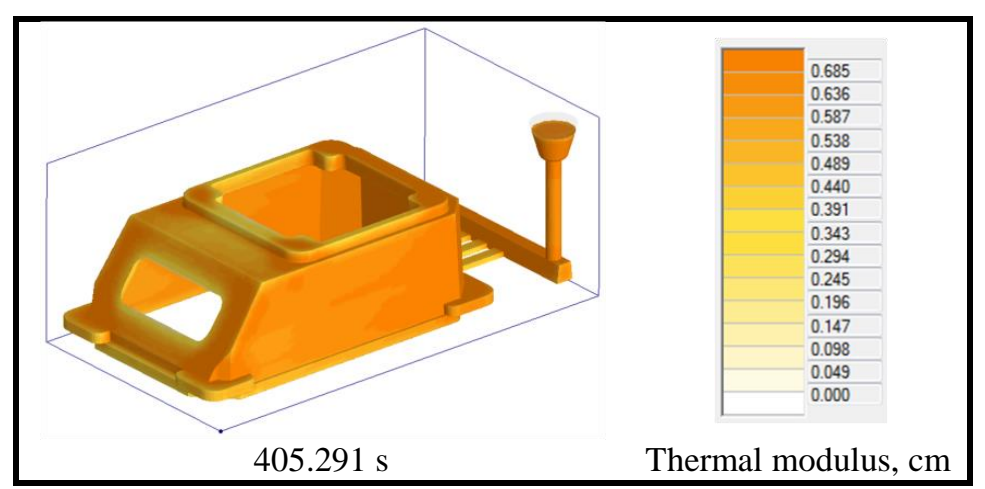

The calculated field of volumetric shrinkage of the casting material is presented in table 14. As a result of the occurrence of shrinkage, the casting volume after solidification in the sand mould was amounted to $98 \%$. 


\begin{tabular}{l|lrl|l|ll} 
& ISRA (India) & $=\mathbf{1 . 3 4 4}$ & SIS (USA) & $=\mathbf{0 . 9 1 2}$ & ICV (Poland) & $=\mathbf{6 . 6 3 0}$ \\
Impact Factor: & ISI (Dubai, UAE) $=\mathbf{0 . 8 2 9}$ & PVHIL (Russia) $=\mathbf{0 . 2 3 4}$ & PIF (India) & $=\mathbf{1 . 9 4 0}$ \\
& GIF (Australia) & $\mathbf{0 . 5 6 4}$ & ESJI (KZ) & $=3.860$ & IBI (India) & $=\mathbf{4 . 2 6 0}$
\end{tabular}

Volumetric shrinkage of the casting material.

Table 14

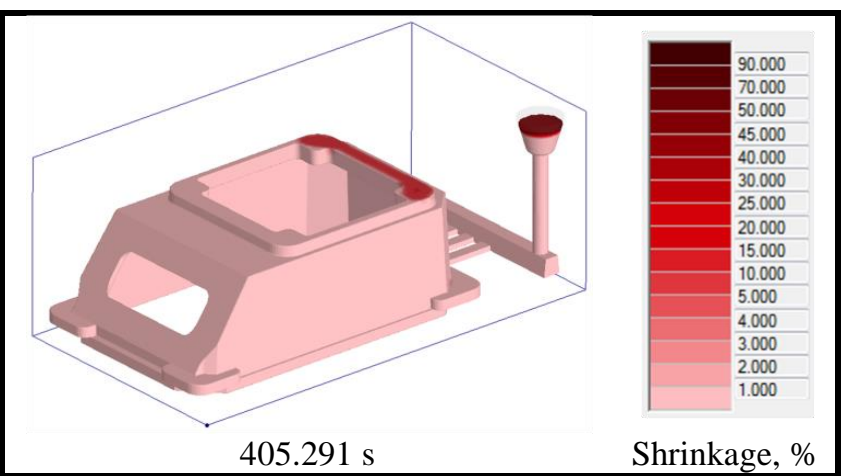

The thermal modulus is ratio of the casting volume to its surface $(V / s)$. For determination of the thermal modulus it is used the following formula: $m=k \sqrt{t}$, where $k=\frac{1}{\sqrt{t_{0}}}-$ the coefficient of proportionality, $t-$ the solidification time of the casting (in seconds), $t_{0}$ - the crystallization time of the material by a diameter of $1 \mathrm{~cm}$ (in seconds). Insufficient risering is observed on the most darkened areas of the model.
In accordance with the basic technological process, calculated volumetric shrinkage of the casting material doesn't exceed the permissible value of shrinkage. However, in the bottom part of the casting, volumetric shrinkage was amounted to $10 \%$. This defect is the result of uneven solidification of the casting in the sand mould. For elimination of this defect it is necessary to perform the calculation of the dimensions of the (gates) feeders of the gating system.

The calculated field of the Niyama criterion for the casting material is presented in table 15 .

Table 15

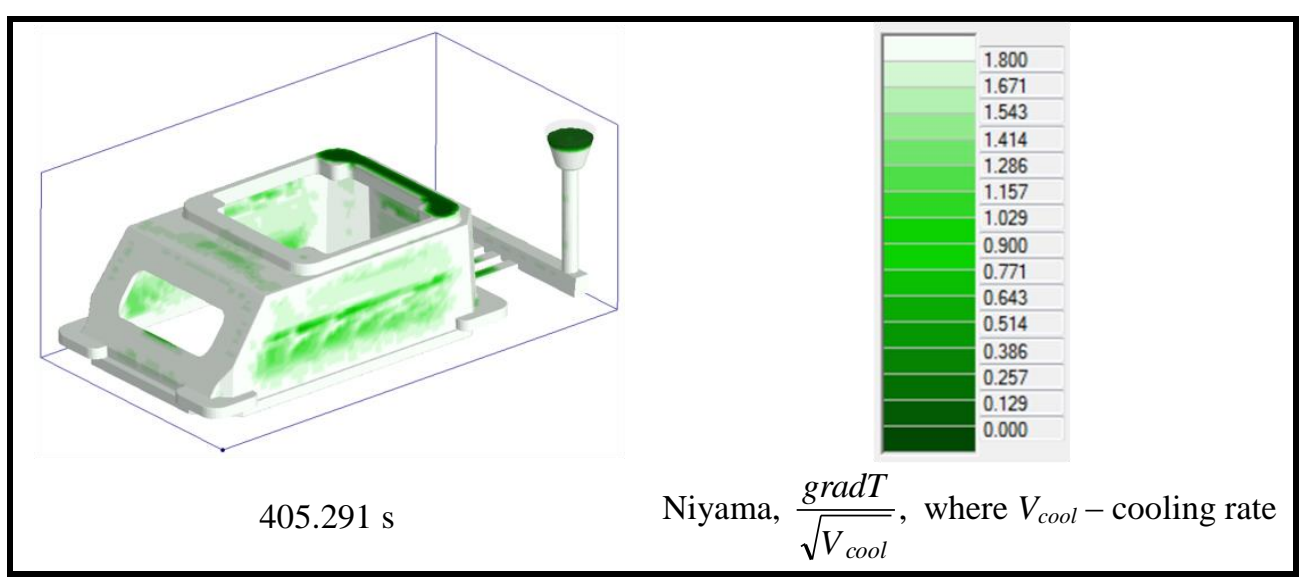

The Niyama criterion allows to predict the forecast of the formation of microporosity and shrinkage porosity in the casting material. The criterion is determined from ratio of the temperature gradient to cooling rate of the casting. The values of the both parameters are taken at the end of solidification of the casting. Then the less value of the Niyama criterion, that there is the more probability of the formation of shrinkage porosity. In accordance with the calculated field, shrinkage porosity is formed in the bottom part and on two symmetrical side walls of the casting.

The calculated values of parameters of the casting process in the sand mould are presented in the summary table 16. 


\begin{tabular}{|c|c|c|c|c|c|c|}
\hline Impact Factor: & $\begin{array}{l}\text { ISRA (India) } \\
\text { ISI (Dubai, UAE } \\
\text { GIF (Australia) } \\
\text { JIF }\end{array}$ & $\begin{array}{l}=1.344 \\
=0.829 \\
=0.564 \\
=1.500\end{array}$ & $\begin{array}{l}\text { SIS (USA) } \\
\text { PИНЦ (Russia) } \\
\text { ESJI (KZ) } \\
\text { SJIF (Morocco) }\end{array}$ & $\begin{array}{l}=0.912 \\
=0.234 \\
=3.860 \\
=\mathbf{2 . 0 3 1}\end{array}$ & $\begin{array}{l}\text { ICV (Poland) } \\
\text { PIF (India) } \\
\text { IBI (India) }\end{array}$ & $\begin{array}{l}=6.630 \\
=1.940 \\
=4.260\end{array}$ \\
\hline
\end{tabular}

The parameters of the casting process.

Table 16

\begin{tabular}{|c|c|c|c|c|c|}
\hline Time, $\mathbf{s}$ & Filled volume, $\%$ & Mass, $\mathbf{k g}$ & Liquid phase, $\%$ & Volume shrinkage, $\boldsymbol{\%}$ & $\mathbf{T}_{\text {max. }}{ }^{\circ} \mathbf{C}$ \\
\hline 0.004 & 0.1 & 0.02 & 100 & 0 & 1325 \\
\hline 0.9 & 10 & 2.63 & 100 & 0 & 1325 \\
\hline 1.801 & 20 & 5.26 & 99.9 & 0 & 1325 \\
\hline 2.7 & 30 & 7.89 & 99.9 & 0 & 1325 \\
\hline 3.604 & 40 & 10.53 & 99.9 & 0 & 1325 \\
\hline 4.509 & 50 & 13.17 & 99.8 & 0 & 1325 \\
\hline 5.411 & 60 & 15.8 & 99.8 & 0 & 1325 \\
\hline 6.318 & 70.1 & 18.46 & 99.8 & 0 & 1325 \\
\hline 7.225 & 80.1 & 21.1 & 99.7 & 0 & 1325 \\
\hline 8.133 & 90 & 23.76 & 99.7 & 0 & 1325 \\
\hline 9.106 & 100 & 26.53 & 99.6 & 0 & 1325 \\
\hline 10.367 & 100 & 26.53 & 99.5 & 0.65 & 1324.2 \\
\hline 33.581 & 99.3 & 26.53 & 94.2 & 0.83 & 1286.3 \\
\hline 42.522 & 99.2 & 26.53 & 89.4 & 0.96 & 1263.6 \\
\hline 54.691 & 99 & 26.53 & 81.7 & 1 & 1235.4 \\
\hline 62.336 & 99 & 26.53 & 76.6 & 1.03 & 1219.2 \\
\hline 70.312 & 99 & 26.53 & 71.3 & 1.06 & 1203.5 \\
\hline 78.287 & 98.9 & 26.53 & 66 & 1.08 & 1189 \\
\hline 94.239 & 98.9 & 26.53 & 56 & 1.1 & 1163.4 \\
\hline 110.190 & 98.9 & 26.53 & 46.9 & 1.11 & 1147.3 \\
\hline 126.142 & 98.9 & 26.53 & 38.6 & 1.12 & 1146.5 \\
\hline 150.069 & 98.8 & 26.53 & 27.7 & 1.13 & 1145.1 \\
\hline 173.996 & 98.8 & 26.53 & 18.9 & 1.14 & 1144 \\
\hline 221.850 & 98.6 & 26.53 & 8.9 & 06.8 \\
\hline 405.291 & 98 & 26.53 & 0 & & 0 \\
\hline
\end{tabular}

For the feeder size calculation it was used the algorithm NovaCast Foundry Solutions AB [14]. The required quantity of the feeders was determined on the basis of the calculated fields of the casting with shrinkage. Ratios feeder/casting and neck/casting depend on the grade of the alloy and the peculiar properties of the solidification process. For gray cast iron ratios were taken by the values of 1 and 0.7 respectively.

The feeder size calculation for reduce of shrinkage in the bottom part of the casting is given in table 17.

Table 17

The feeder size calculation.

\begin{tabular}{|c|c|}
\hline \multicolumn{2}{|c|}{ Selection of the casting node } \\
\hline \multicolumn{2}{|c|}{} \\
\hline \multicolumn{2}{|c|}{ Input data } \\
\hline Alloy density, $\mathrm{kg} / \mathrm{m}^{3}$ & 6761.017 \\
\hline Casting modulus, cm & 0.84 \\
\hline Casting weight to be fed, kg & 26.806 \\
\hline Minimum feed metal requirement, \% & 2.374 \\
\hline Minimum modulus ratio feeder/casting & 1 \\
\hline
\end{tabular}




\begin{tabular}{|c|c|c|c|c|c|c|}
\hline Impact Factor: & $\begin{array}{l}\text { ISRA (India) } \\
\text { ISI (Dubai, UAE } \\
\text { GIF (Australia) } \\
\text { JIF }\end{array}$ & $\begin{array}{l}=1.344 \\
=0.829 \\
=0.564 \\
=1.500\end{array}$ & $\begin{array}{l}\text { SIS (USA) } \\
\text { PИНЦ (Russia) } \\
\text { ESJI (KZ) } \\
\text { SJIF (Morocco) }\end{array}$ & $\begin{array}{l}=0.912 \\
=0.234 \\
=3.860 \\
=\mathbf{2 . 0 3 1}\end{array}$ & $\begin{array}{l}\text { ICV (Poland) } \\
\text { PIF (India) } \\
\text { IBI (India) }\end{array}$ & $\begin{array}{l}=6.630 \\
=1.940 \\
=4.260\end{array}$ \\
\hline
\end{tabular}

\begin{tabular}{|c|c|}
\hline Feeder ratio height/diameter & 1.5 \\
\hline Modulus ratio neck/casting & 0.7 \\
\hline Feeder type & Cylinder \\
\hline Mould hardness & 80 \\
\hline Location & Top \\
\hline \multicolumn{2}{|c|}{ Result } \\
\hline Minimum feeder modulus, cm & 1.422 \\
\hline Actual modulus ratio feeder/casting & 1.692 \\
\hline Feed metal requirement, $\mathrm{cm}^{3}$ & 131.781 \\
\hline Feeder weight, $\mathrm{kg}$ & 3.472 \\
\hline Modulus feeder neck, $\mathrm{cm}$ & 0.588 \\
\hline Feeder neck dimension square, $\mathrm{mm}$ & 23.531 \\
\hline Minimum feeder diameter, $\mathrm{mm}$ & 75.821 \\
\hline Minimum feeder height, $\mathrm{mm}$ & 113.731 \\
\hline
\end{tabular}

Thus, for supply of the alloy it is necessary the feeder with a minimum diameter of $75.821 \mathrm{~mm}$.

The readings of the temperature, cooling rate, the fraction of the liquid phase, the velocity, pressure, flow and quantity of heat of the alloy from the time of the casting process, obtained from six sensors are presented in Fig. $26-32$.

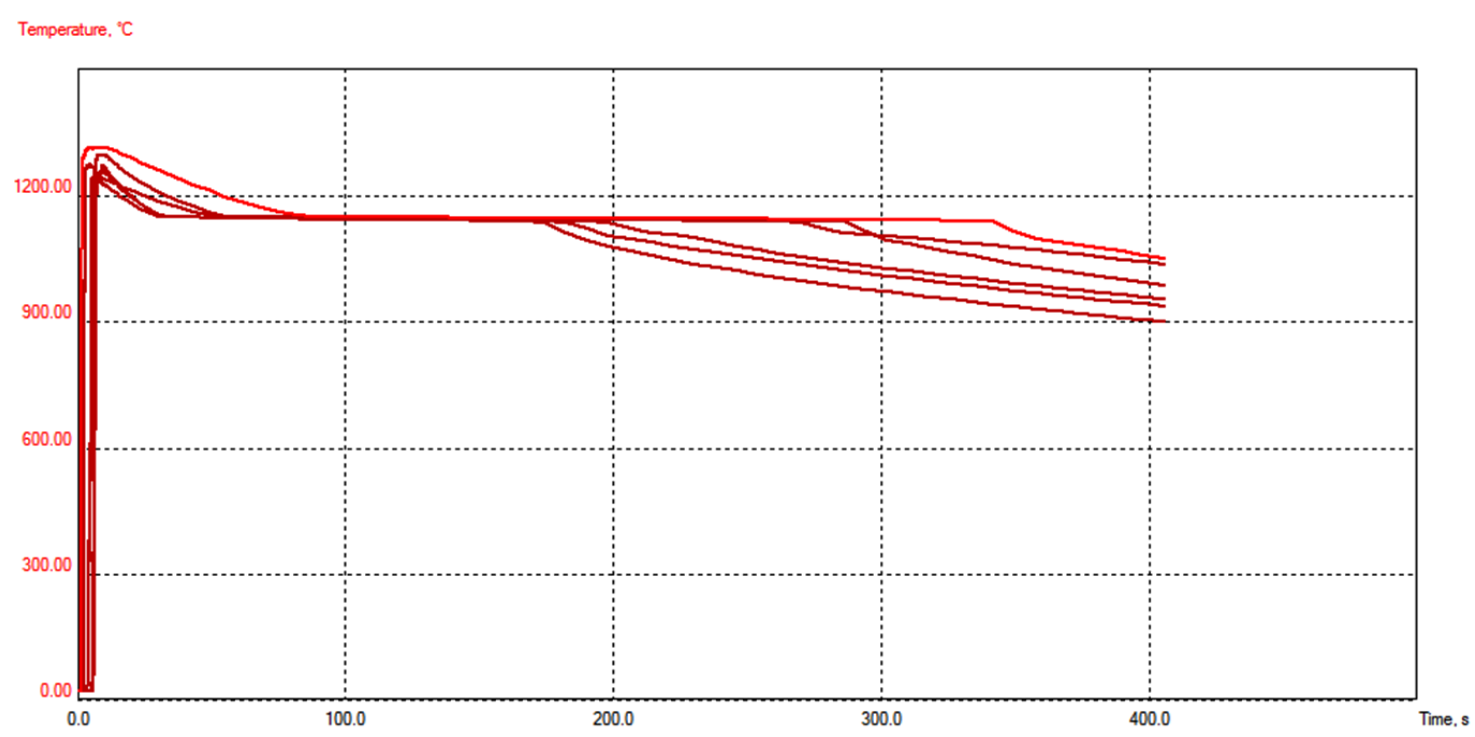

Figure 26 - The dependencies of the temperature of melt from the time of the casting process. 


\begin{tabular}{l|lr|ll|ll} 
& ISRA (India) & $=\mathbf{1 . 3 4 4}$ & SIS (USA) & $=\mathbf{0 . 9 1 2}$ & ICV (Poland) & $=\mathbf{6 . 6 3 0}$ \\
Impact Factor: & ISI (Dubai, UAE) $=\mathbf{0 . 8 2 9}$ & PUHL (Russia) $=\mathbf{0 . 2 3 4}$ & PIF (India) & $=\mathbf{1 . 9 4 0}$ \\
& GIF (Australia) & $=\mathbf{0 . 5 6 4}$ & ESJI (KZ) & $=\mathbf{3 . 8 6 0}$ & IBI (India) & $\mathbf{= 4 . 2 6 0}$
\end{tabular}

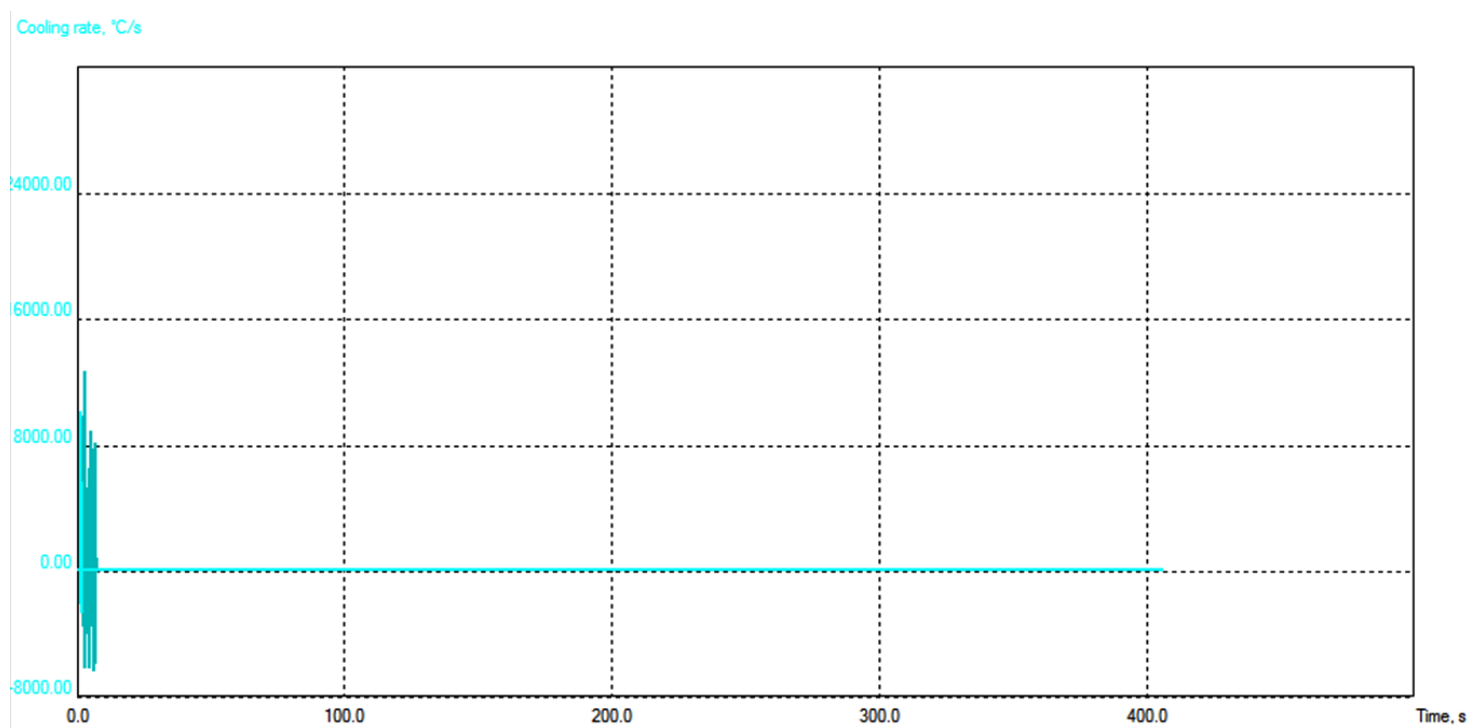

Figure 27 - The dependence of cooling rate of melt from the time of the casting process.

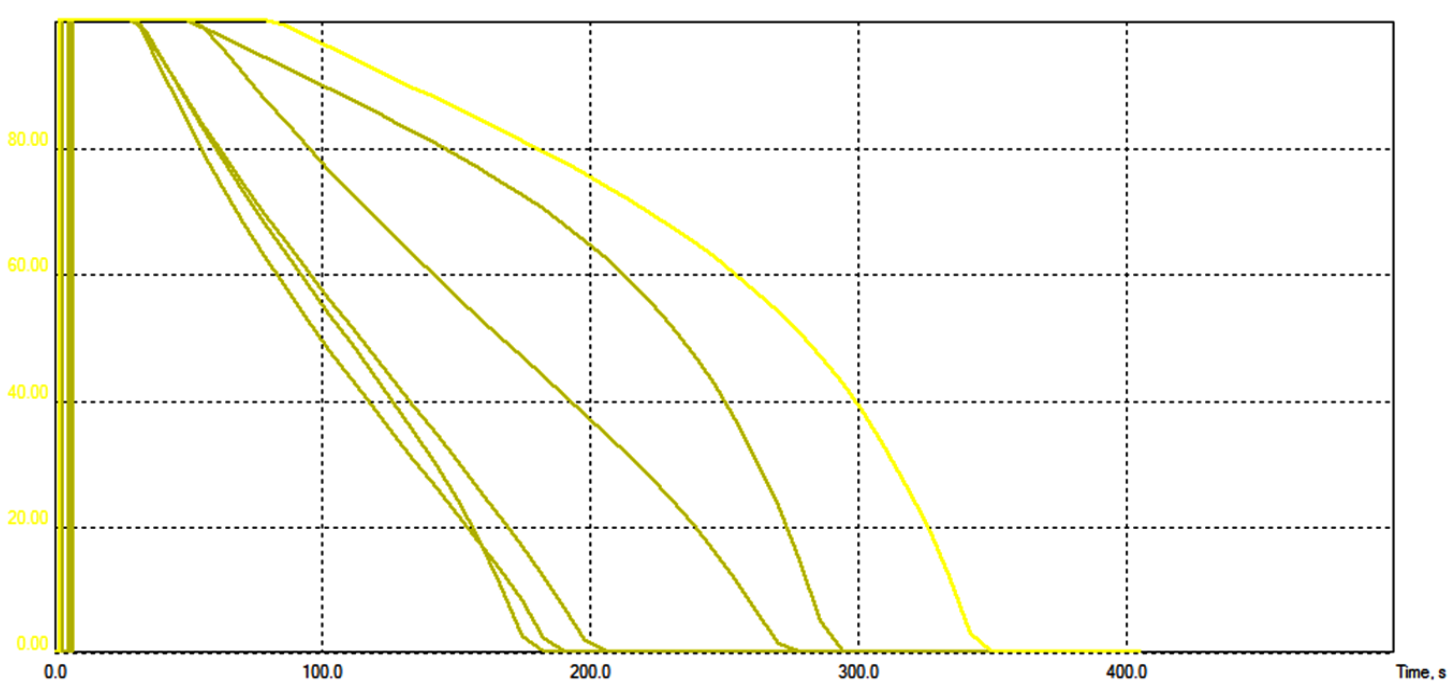

Figure 28 - The dependencies of the phase fraction of melt from the time of the casting process.

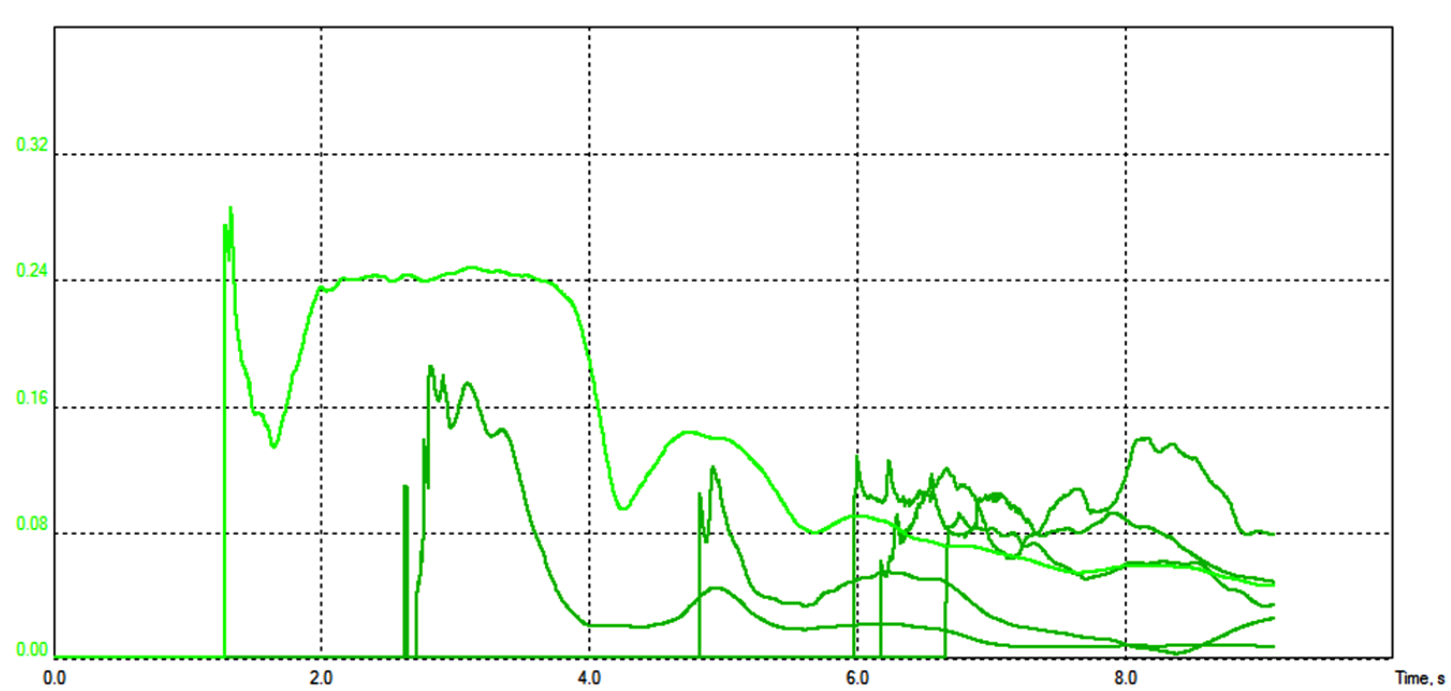

Figure 29 - The dependencies of the flow velocity of melt from the time of the mould filling. 


\begin{tabular}{l|lr|ll|ll} 
& ISRA (India) & $=\mathbf{1 . 3 4 4}$ & SIS (USA) & $=\mathbf{0 . 9 1 2}$ & ICV (Poland) & $=\mathbf{6 . 6 3 0}$ \\
Impact Factor: & ISI (Dubai, UAE) $=\mathbf{0 . 8 2 9}$ & PUHI (Russia) & $=\mathbf{0 . 2 3 4}$ & PIF (India) & $=\mathbf{1 . 9 4 0}$ \\
& GIF (Australia) & $=\mathbf{0 . 5 6 4}$ & ESJI (KZ) & $=\mathbf{3 . 8 6 0}$ & IBI (India) & $\mathbf{4 . 2 6 0}$ \\
& JIF & $\mathbf{1 . 5 0 0}$ & SJIF (Morocco) & $\mathbf{2 . 0 3 1}$ & & \\
\hline
\end{tabular}

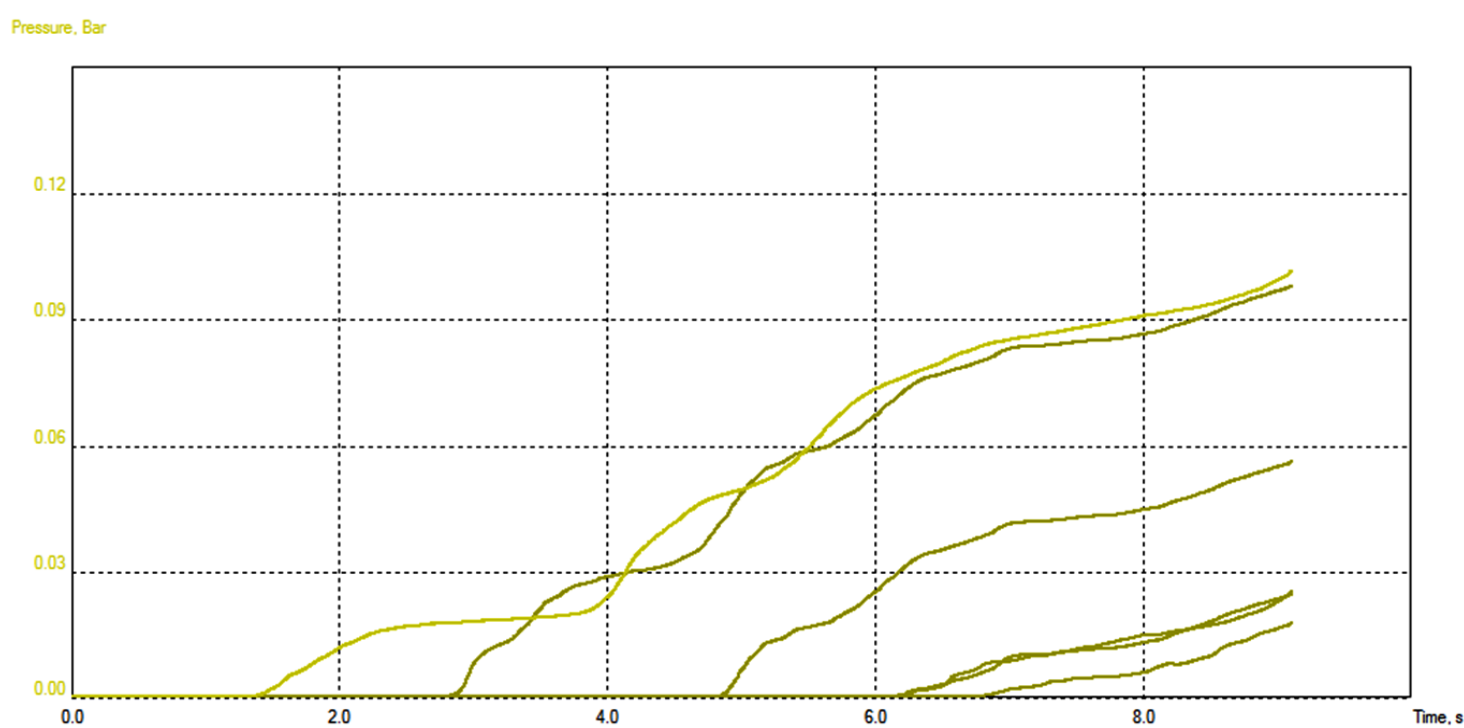

Figure 30 - The dependencies of pressure in melt from the time of the mould filling.

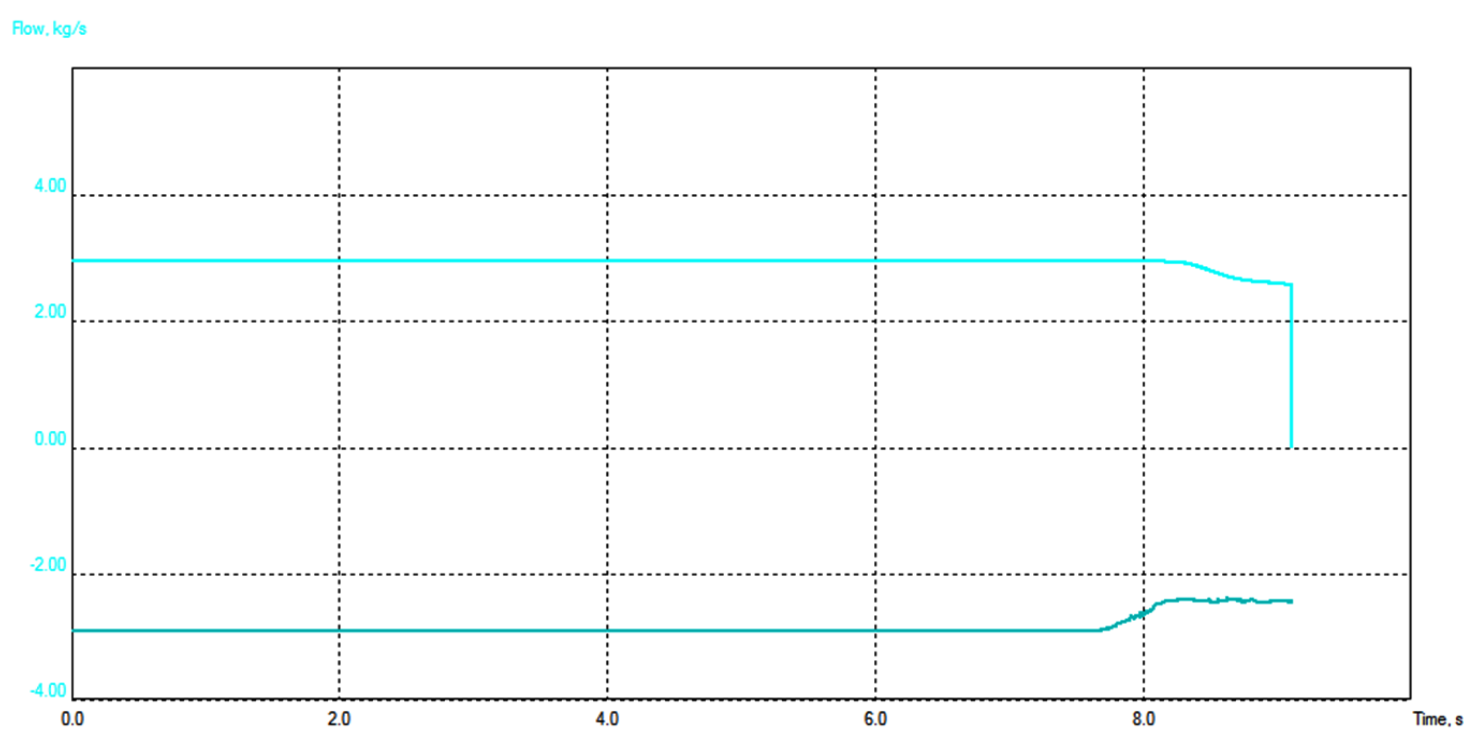

Figure 31 - The change of melt flow from the time of the mould filling.

Quantity of heat, MJ

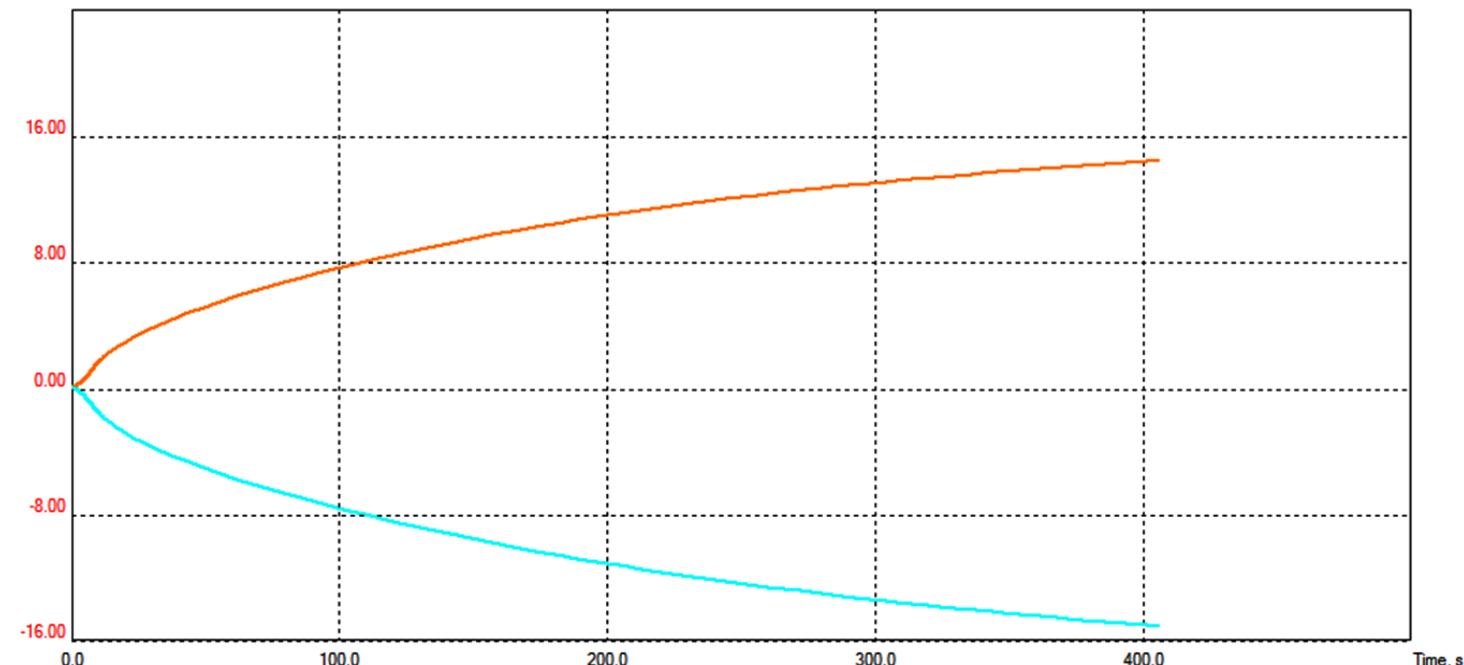

Figure 32 - The change of the quantity of heat of melt from the time of the mould filling. 
The fluctuations of cooling rate of melt were determined at the stage of the mould filling. The solidification process occurs with a constant rate of cooling of the inner layers of the alloy.

On the chart of flow, the upper dependence is melt flow on the sprue, the lower dependence is melt flow on the flowmeter.

The chart of the quantity of heat determines the change of the quantity of heat in the alloy and
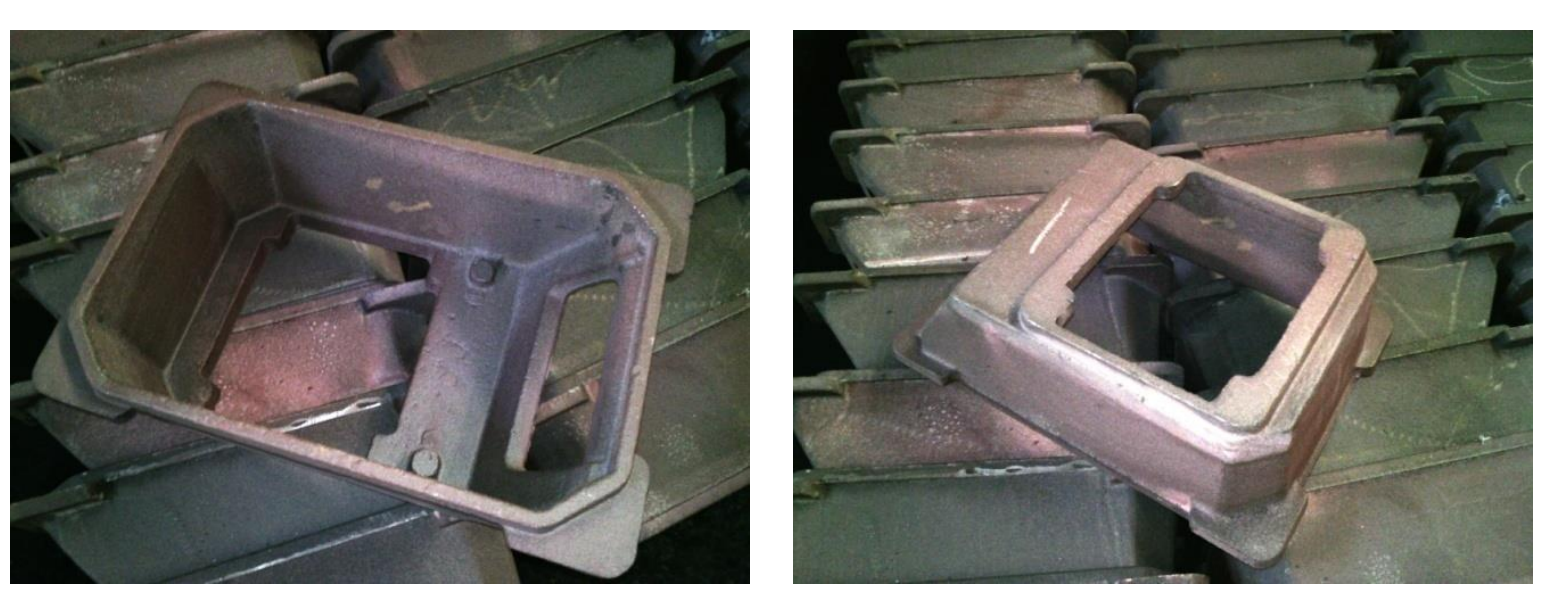

Figure 33 - The casting of frame of the terminal box.
The results of the computer simulation will be useful in the selection of the foundry equipment and the implementation of the optimization of the casting process.

\section{Conclusion}

The performed analysis of the results of the finite element simulation of the casting process of grey cast iron in the sand mould allows to draw the following conclusions: $\mathrm{kg} / \mathrm{s}$, was amounted to $405.291 \mathrm{~s}$. This is approximately on 17 minutes less than exposure time of the casting in the sand mould in accordance with the basic technological process.

2. The casting in the sand mould is cooled unevenly. It leads to the formation of local residual stresses in the casting material. Such deformations
1. The time of casting, when melt flow is 2.921 moulding sand since the beginning of the simulation of the casting process. The colors of the dependencies correspond to the colors of the models of materials. The casting gives off heat (negative values), moulding sand takes heat (positive values). The process of heat transfer is uniform.

The general view of the casting, manufactured under production conditions, is presented in Fig. 33. are most exposed remote from the feeders layers of the material, the bottom part and the side walls of the casting.

3. Calculated volumetric shrinkage of the material exceeds acceptable shrinkage in 10 times in the bottom part of the casting. The presented calculation of the required dimensions of the feeder allows to eliminate this type of defect of the casting.

4. The formation of shrinkage porosity is characterized by cooling rate of grey cast iron (at the temperature of full crystallization). It was obtained the critical value of the Niyama criterion $\left(N_{y}=1.8\right)$, below which porosity in the casting material is formed. Probability of the formation of shrinkage porosity in more degree is occurred on two symmetric side walls and the part of the bottom surface of the casting.

\section{References:}

1. (2017) Vladimir electromotive plant. Available: http://www.vemp.ru (Accessed: 07.06.2017).

2. (2017) Sand casting. Available: https://en.wikipedia.org/wiki/Sand_casting (Accessed: 07.06.2017).
3. (2009) GOST 53464-2009. Metal and alloy castings. Dimensions and mass tolerances and machining allowances.

4. (1992) GOST 3212-92. Gated patterns. Pattern tapers, core prints, dimensional tolerances. 


\begin{tabular}{l|lrl|l|ll} 
& ISRA (India) & $=\mathbf{1 . 3 4 4}$ & SIS (USA) & $=\mathbf{0 . 9 1 2}$ & ICV (Poland) & $=\mathbf{6 . 6 3 0}$ \\
Impact Factor: & ISI (Dubai, UAE) $=\mathbf{0 . 8 2 9}$ & PUHL (Russia) $=\mathbf{0 . 2 3 4}$ & PIF (India) & $=\mathbf{1 . 9 4 0}$ \\
& GIF (Australia) & $\mathbf{0 . 5 6 4}$ & ESJI (KZ) & $=3.860$ & IBI (India) & $=\mathbf{4 . 2 6 0}$ \\
& JIF & $=\mathbf{1 . 5 0 0}$ & SJIF (Morocco) & $=\mathbf{2 . 0 3 1}$ & & \\
\hline
\end{tabular}

5. (1985) GOST 3.1401-85. Unified system of technological documentation. Forms and rules of making documents on technological processes of casting.

6. (2007) GOST 52781-2007. Grinding and toolgrinding wheels. Specifications.

7. (2017) Iron-Carbon Phase Diagram (a review) see Callister Chapter 9. MSE 300 Materials Laboratory Procedures. University of Tennessee, Dept. of Materials Science and Engineering.

8. (2017) LVMFlow. Available: http://lvmflow.ru (Accessed: 07.06.2017).

9. Carlson K, Beckermann C (2009) Prediction of Shrinkage Pore Volume Fraction Using a Dimensionless Niyama Criterion. AFS., Trans. Vol. 40A. - pp. 163 - 175.

10. Polyakov S, Korotchenko A, Bast J (2011) Use of the Niyama criterion to predict porosity of the mushy zone with deformation. Archives of foundry engineering, Volume 11, Issue 4. - pp. $131-136$.

11. (2017) Gauss-Seidel method. Available: https://en.wikipedia.org/wiki/GaussSeidel_method (Accessed: 07.06.2017).

12. Chemezov D, Bayakina A, Bogomolova E, Lukyanova T (2017) To the question of the solidification process of steel castings with different wall thicknesses. ISJ Theoretical \& Applied Science, 03 (47): 38 - 41. Soi: http://so-i.org/1.1/TAS-03-47-8 Doi: https://dx.doi.org/10.15863/TAS.2017.03.47.8

13. Krutilin AN, Lushchik PE, Andrits AA (2014) The analysis of the tensions working in casting at vertical semi-continuous molding of cast iron. Foundry and metallurgy, № 4 (77). - pp. $10-18$.

14. (2017) NovaCast Technologies AB. Available: http://www.ruscastings.ru/work/168/2130/2984/ 2988 (Accessed: 07.06.2017). 